\title{
Long-Term Goals for Solar Thermal Technology
}

\author{
T. A. Williams \\ J. A. Dirks \\ D. R. Brown
}

May 1985

Prepared for the U.S. Department of Energy under Contract DE-AC06-76RLO 1830

Pacific Northwest Laboratory Operated for the U.S. Department of Energy by Battelle Memorial Institute 


\title{
DISCLAIMER
}

This report was prepared as an account of work sponsored by an agency of the United States Government. Neither the United States Government nor any agency thereof, nor any of their employees, makes any warranty, express or implied, or assumes any legal liability or responsibility for the accuracy, completeness, or usefulness of any information, apparatus, product, or process disclosed, or represents that its use would not infringe privately owned rights. Reference herein to any specific commercial product, process, or service by trade name, trademark, manufacturer, or otherwise, does not necessarily constitute or imply its endorsement, recommendation, or favoring by the United States Government or any agency thereof. The views and opinions of authors expressed herein do not necessarily state or reflect those of the United States Government or any agency thereof.

\author{
PACIFIC NORTHWEST LABORATORY \\ operated by \\ BATTELLE \\ for the \\ UNITED STATES DEPARTMENT OF ENERGY \\ under Contract DE-AC06-76RLO 1830
}

\begin{tabular}{|c|c|}
\hline \multicolumn{2}{|c|}{ Printed in the United States of America } \\
\hline \multicolumn{2}{|c|}{ Available from } \\
\hline \multicolumn{2}{|c|}{ National Technical Information Service } \\
\hline \multicolumn{2}{|c|}{$\begin{array}{l}\text { National lechnical Information Service } \\
\text { United States Department of Commerce }\end{array}$} \\
\hline 5285 & oad \\
\hline \multicolumn{2}{|c|}{ Springfieid, Virginia 22161} \\
\hline \multirow{2}{*}{\multicolumn{2}{|c|}{$\begin{array}{l}\text { NTIS Price Codes } \\
\text { Microfiche A01 }\end{array}$}} \\
\hline & \\
\hline \multicolumn{2}{|c|}{ Printed Copy } \\
\hline & \\
\hline Pages & Codes \\
\hline $001-025$ & $\mathrm{~A} 02$ \\
\hline 026-050 & $\mathrm{A} 03$ \\
\hline $051-075$ & A04 \\
\hline 076-100 & A05 \\
\hline $101-125$ & A06 \\
\hline $126-150$ & A07 \\
\hline $151-175$ & $\mathrm{~A} 0 \mathrm{~B}$ \\
\hline $176-200$ & $\mathrm{~A} 09$ \\
\hline $201-225$ & A010 \\
\hline $226-250$ & A011 \\
\hline $251-275$ & A012 \\
\hline $276-300$ & $A 013$ \\
\hline
\end{tabular}


PNL -5463

UC -62

LONG-TERM GOALS FOR SOLAR

THERMAL TECHNOLOGY

T. A. Williams

J. A. Dirks

D. R. Brown

May 1985

Prepared for

the U.S. Department of Energy

under Contract DE-AC06-76RLO 1830

Pacific Northwest Laboratory

Richland, Washington 99352 
4

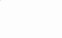

* A 


\section{PREFACE}

The research and development described in this report was conducted within the U.S. Department of Energy's (OOE's) Solar Thermal Technology Program. The efforts of that program are directed toward advancing solar thermal technologies through research and development of solar thermal materials, components, and subsysteris, and through testing and evaluation of solar thermal systems. These efforts are conducted through DOE and its network of national laboratories, which work with private industry. Together they have established a goaldirected program for providing technically proven and economically competitive options -or incorporation into the nation's energy supply.

This report describes the development of the program goals, $\$ 0.05 / \mathrm{kW}-\mathrm{hr}$ for electricity production and $\$ 9 / M B t u$ for industrial process heat production, for the two primary solar thermal technologies, central receivers and distributed receivers. These technologies use various point and line-focus optics to concentrate sunlight onto receivers, where the solar energy is absorbed as heat and converted to electricity or used as process heat. 


\section{ACKNOWLEDGMENTS}

Many organizations and individuals contributed to the process of developing solar thermal technology goals by supplying estimates of solar thermal capabilities and by reviewing draft versions of the goals. In particular, we wish to thank Sandia Laboratories in Livermore, California. 


\section{EXECUTIVE SUMMARY}

This document describes long-term performance and cost goals for three solar thermal technologies. Pacific Northwest Laboratory (PNL) developed these goals in support of the Draft Five Year Research and Development Plan for the National Solar Thermal Technology Program (DOE 1984b). These technology goals are intended to provide targets that, if met, will lead to the widespread use of solar thermal technologies in the marketplace. Goals were developed for three technologies and two applications: central receiver and dish technologies for utility-generated electricity applications, and central receiver, dish, and trough technologies for industrial process heat applications. These technoloyies and applications were chosen because they are the primary technologies and applications that have been researched by DoE in the past.

Sys:em goals were developed through analysis of future price projections for enerigy sources competing with solar thermal in the middle-to-late 1990's time frame. The system goals selected were levelized energy costs of $\$ 0.05 / k$ wh for elecricity and $\$ 9 / M B t u$ for industrial process heat (1984\$). Component goals es:ablished to meet these system goals were developed based upon projections of solar thermal component performance and cost which could be achieved in the same time frame. The component goals developed are shown in Table S.1. 
TABLE S.1. Long-Term Component Goals

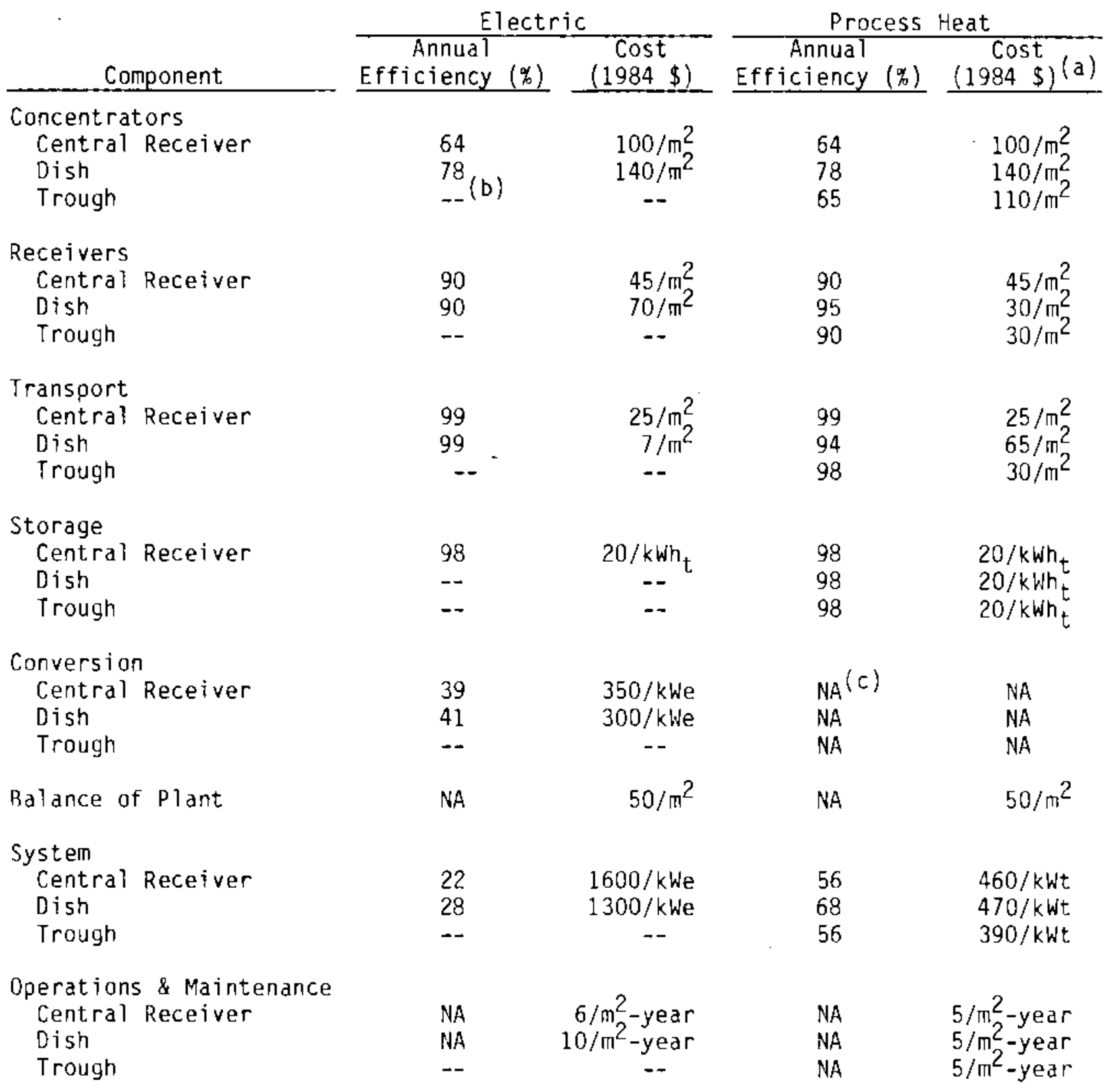

(a) System costs in $\$ / \mathrm{kW}$ are based on theoretical power available from receiver. (b) Technology goals not developed for trough electricity.

(c) $N A=$ Not applicable. 


\section{CONTENTS}

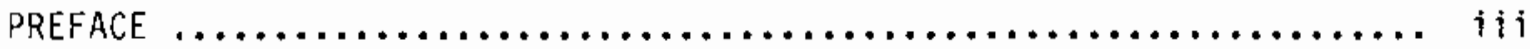

ACKNOWLEUGMENTS $\ldots \ldots \ldots \ldots \ldots \ldots \ldots \ldots \ldots \ldots \ldots \ldots \ldots \ldots \ldots \ldots \ldots \ldots \ldots$

EXECUTIVE SUMMARY $\ldots \ldots \ldots \ldots \ldots \ldots \ldots \ldots \ldots \ldots \ldots \ldots \ldots \ldots \ldots \ldots \ldots \ldots \ldots \ldots \ldots \ldots$

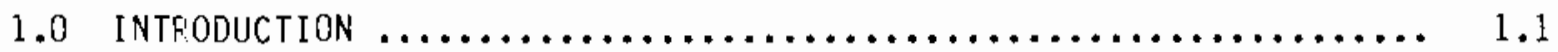

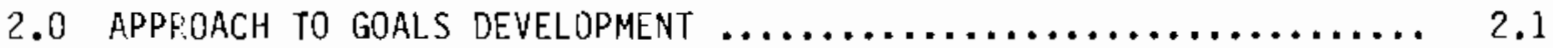

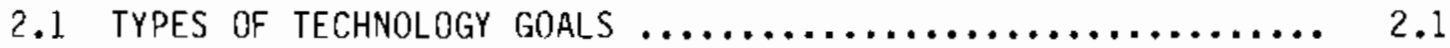

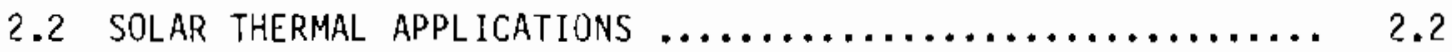

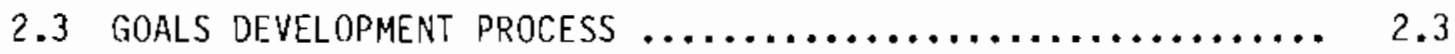

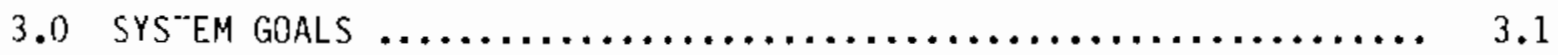

3.1 SYSTEM GOALS FOR ELECTRICITY $\ldots \ldots \ldots \ldots \ldots \ldots \ldots \ldots \ldots \ldots \ldots \ldots \ldots \ldots \ldots$

3.2 SYSTEM GOALS FOR INDUSTRIAL PROCESS HEAT $\ldots \ldots \ldots \ldots \ldots \ldots \ldots \ldots .3 .7$

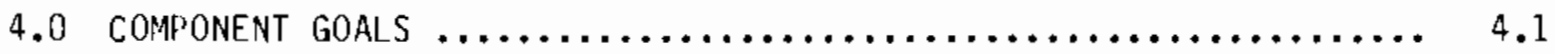

4.1 COSt AND PERformanCE DEFinitions $\ldots \ldots \ldots \ldots \ldots \ldots \ldots \ldots \ldots \ldots . . .1$

4.1.1 Equipment and Cost Definitions $\ldots \ldots \ldots \ldots \ldots \ldots \ldots \ldots . .1$

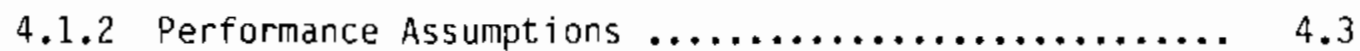

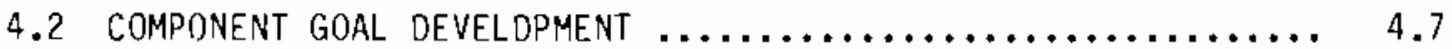

4.3 COMPONENT GOALS AND SUPPORTING REFERENCES $\ldots \ldots \ldots \ldots \ldots \ldots .4 .11$

5.0 ALTERNATIVE GOALS AND SYSTEM TRAUEOFFS $\ldots \ldots \ldots \ldots \ldots \ldots \ldots \ldots \ldots . \ldots \ldots$

5.1 ALTERNATIVE COMPONENT GOALS $\ldots \ldots \ldots \ldots \ldots \ldots \ldots \ldots \ldots \ldots \ldots \ldots \ldots \ldots \ldots \ldots$

5.2 CAPITAL INVESTMENT, SYSTEM EFFICIENCY, AND ANNUAL
O\&M TRADEOFFS $\ldots \ldots \ldots \ldots \ldots \ldots \ldots \ldots \ldots \ldots \ldots \ldots \ldots \ldots \ldots \ldots \ldots \ldots \ldots \ldots$

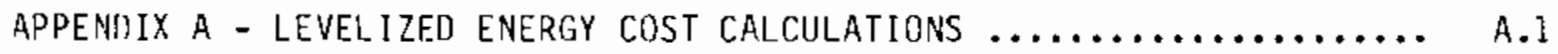

APPENOIX B - LEVELIZED ENERGY COST ESTIMATES FOR

COAL -FIRED POWER PLANTS $\ldots \ldots \ldots \ldots \ldots \ldots \ldots \ldots \ldots \ldots \ldots \ldots \ldots \ldots \ldots \ldots \ldots$

APPENDIX $c$ - TECHNOLOGY DATA SHEETS $\ldots \ldots \ldots \ldots \ldots \ldots \ldots \ldots \ldots \ldots \ldots \ldots \ldots \ldots \ldots$ 
APPENDIX 0 - PERFORMANCE AND COST CHARACTERISTICS OF NEAR-TERM

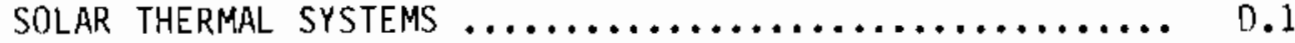

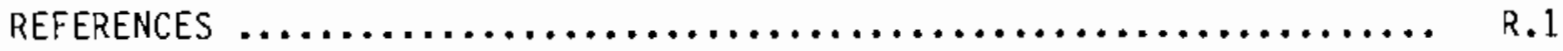




\section{FIGURES}

2.1 Relationship Between System and Component Goals $\ldots \ldots \ldots \ldots \ldots \ldots .2$

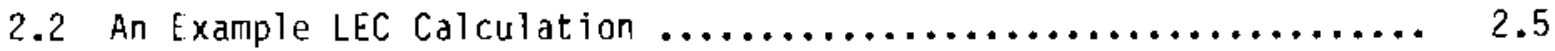

3.1 Range of Projected Energy Costs for Coal Plants ............ 3.5

3.2 Residual Price Projections in Support of the National Energy Policy Plan ..................................... 3.9

3.3 Residual Projections in Support of the National Energy Policy plan ........................................ 3.10

3.4 Distillate Price Projections in Support of the National Energy Policy plan ........................................ 3.11

3.5 Distillate Projections in Support of the National Energy Policy Plan ....................................... 3.11

3.6 Natural Gas Price Projections in Support of the National Energy Policy Plan ................................. 3.12

3.7 Natural Gas Projections in Support of the National Energy Policy Plan ........................................ 3.12

3.8 LEC Using 1990 EIA Projections (residual fuel -

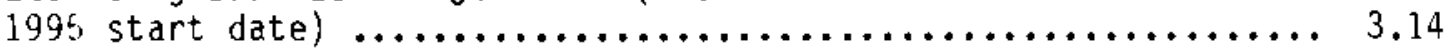

3.9 LEC Using 1990 EIA Projections (natural gas -

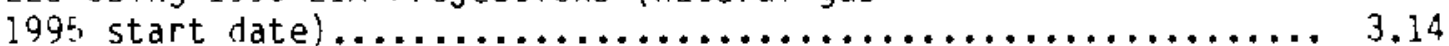




\section{TABLES}

S.1 Long-Term Component Goals $\ldots \ldots \ldots \ldots \ldots \ldots \ldots \ldots \ldots \ldots \ldots \ldots \ldots$ vi

3.1 Energy Consumption for the Production of Electricity $\ldots \ldots \ldots \ldots .3$

3.2 Range of Coal Plant Characteristics Used in Estimating

Levelized Energy Cost ........................... 3.5

3.3 0il-Fired Electric Plant Characteristics Used in Estimating

Leve ized Energy Cost ............................ 3.6

3.4 Industrial Fuel and Power Consumption Estimates $\ldots \ldots \ldots \ldots \ldots \ldots . . .3$

4.1 Long-Term Component Gods ......................... 4.10

4.2 Concentrator Goals and Supporting References $\ldots \ldots \ldots \ldots \ldots \ldots \ldots . .11$

4.3 Receiver Goals and Supporting References $\ldots \ldots \ldots \ldots \ldots \ldots \ldots \ldots \ldots .12$

4.4 Transport Goals and Supporting References $\ldots \ldots \ldots \ldots \ldots \ldots \ldots \ldots . \ldots .13$

4.5 Storage Goals and Supporting References $\ldots \ldots \ldots \ldots \ldots \ldots \ldots \ldots . . . . .4$

4.6 Conversion Goals and Supporting References .............. 4.15

4.7 Balance of Plant Goals and Supporting References ........... 4.16

4.8 System Goals and Supporting References $\ldots \ldots \ldots \ldots \ldots \ldots \ldots \ldots \ldots . . \ldots \ldots$

4.9 O\&M Goals and Supporting References $\ldots \ldots \ldots \ldots \ldots \ldots \ldots \ldots \ldots \ldots . . \ldots \ldots$

5.1 Central Receiver Electric $\ldots \ldots \ldots \ldots \ldots \ldots \ldots \ldots \ldots \ldots \ldots \ldots \ldots \ldots .4$

5.2 Central Receiver Industrial Process Heat $\ldots \ldots \ldots \ldots \ldots \ldots \ldots \ldots .4$

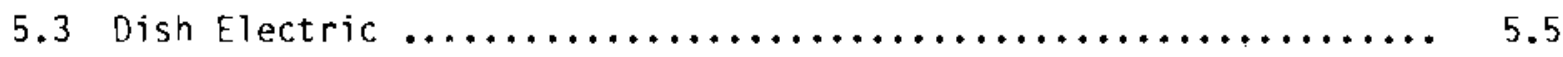

5.4 Dish Industrial Process Heat $\ldots \ldots \ldots \ldots \ldots \ldots \ldots \ldots \ldots \ldots \ldots \ldots \ldots$

5.5 Trough Industrial Process Heat $\ldots \ldots \ldots \ldots \ldots \ldots \ldots \ldots \ldots \ldots \ldots \ldots$

5.6 Tradeoff Equation Parameters $\ldots \ldots \ldots \ldots \ldots \ldots \ldots \ldots \ldots \ldots \ldots \ldots \ldots$ 


\subsection{INTRODUCTION}

To promote the widespread use of solar thermal technologies in the marketplace, the U.S. Department of Energy (DOE) sponsored through Sandia Laboratories a project to develop long-term performance and cost goals for three solar thermal technologies and two applications. The goals were developed by PNL in support of the draft 1985-1989 Five Year Research and Development Plan (DOE 1984b) for DOE's National Solar Thermal Technology Progran. The objective of the solar thermal technology program is to establish solar thermal technologies as technically and economically attractive energy sources by conducting research in cooperation with the private sector. To achieve this objective, the capabilities and potential of solar thermal technology had to be determined, and the energy sources that solar energy must compete against in the economic marketplace had to be examined.

To astablish solar thermal technologies as a viable energy source, the delivered cost of solar thermal energy must decrease until it is economically competitive with other energy sources. The technology goals developed for solar thermal systems therefore addressed two fundamental issues: 1) the energy cost that solar themal systems must achieve to have a significant impact in the energy market, and 2) the development of components of a solar thermal plant that will technically attain this energy cost.

To determine the characteristics of competitive energy sources and the capabilizies of solar thermal components, PNL developed two types of technology goals: system and component goals. System goals are energy price targets which must be met for solar thermal to be economically viable in a given market, and therefore were determined primarily by the characteristics (e.g., price, availability, etc.) of competing energy sources.

Component goals focus on the performance and cost of solar thermal technology. In this project, component goals were directed toward providing a path for sola thermal technology development that will result in achieving the desired levelized energy cost for the systen. Component goa's were selected based on considerations of component performance and cost improvements that could be attained through solar thermal research and development (R\&D). 
Component goals were developed for the portions of a solar thermal plant that are major cost elements, important drivers of plant efficiency, or areas of significant interest for R\&D. Based on these criteria, eight areas were devised for component goal development: concentrators, receivers, energy transport, energy storage, energy conversion, balance of plant, installed system cost, and operations and maintenance (0\&M) costs. These eight areas cover all areas of cost in a solar thermal plant and also provide a suitable level of detail to allocate targets to the individual research task activities within DOE's solar thermal program.

Solar thermal energy systems have many applications. By varying the concentration ratio in the solar collector, the delivery temperature of the collected thermal energy can be varied from $100^{\circ} \mathrm{C}$ to well over $1000^{\circ} \mathrm{C}$. Electricity can be produced directly through a themal conversion cycle, or the heat output from the plant could be input to any number of industrial processes. Additional design flexibility (from tens of kilowatts to hundreds of megawatts) and operating flexibility (through the use of thermal storage and/or hybridization) make it technically feasible for solar thermal to compete with conventional fuel sources for a wide range of uses.

The two primary applications chosen for the development of technology goals were electricity and industrial process heat (IPH). The electric system goals were based upon utility-owned, grid-connected power production. System goals for IPH applications assumed industrial ownership of a solar thermal plant producing mid- to high-temperature (200 to over $600^{\circ} \mathrm{C}$ ) process heat. Several other applications, such as remote solar themal power plants and electricity-producing plants owned by third parties, could potentially represent significant markets for solar thermal technology but were not considered in developing the system goals.

The technology goals were developed for the middle-to-late-1990's time frame, and therefore required projections of future cost and performance for energy sources competing with solar thermal. For electric utility applications, oil-fired and coal-fired plants were used as the competing energy sources. For industrial process heat applications, $0 i 1$ and natural gas were used as the target competition for solar thermal. A levelized energy cost 
approach was used to analyze long-term projections of the prices for these energy sources to establish system-ievel goals for solar thermal.

As a tool for assessing research directions, both system and component goals must be flexible to be updated as circumstances change. Appropriate system goals could vary because of many changes, such as changes in projected price increases of conventional energy sources, changes in the target applications in which solar thernal will compete, or changes in the regulatory environment (such as tax treatment or pollution control standards) for these applications. The best allocation of component goals may vary in the future when the ultimate performance and cost of solar thermal components become known with more certainty. For example, a component designed for moderate performance/low cost could be more desirable than the same component designed for high performance/moderate cost. Similariy, if the development path for some solar thermal components allows the component to exceed its goal, then more flexibility exists for attaining other components goals (lower perforinance or higher cost), while still achieving the system goal. 
- 


\section{D APPROACH TO GOALS DEVELOPMENT}

In developing technology goals, significant issues that must be addressed include the type of goals to be used, the applications for which goals will be developet, and the process to be used in developing the goals. Each of these issues is discussed separately below.

\subsection{TYPES OF TECHNOLOGY GOALS}

Solur thermal technology goals address two fundamental issues: the energy cost tha: solar thermal systems must achieve to have a significant impact in the enerigy market, and development of the components of a solar thermal plant to attain this energy cost. These issues were addressed separately through the use of s:ytem and component goals.

The system goals addressed the issue of the economic characteristics required for solar thermal to compete in the energy market. System goals are expresseld in energy cost units $(\$ / \mathrm{kWh}$ or $\$ / \mathrm{ABtu}$ ) and as such represent both performance and cost attributes required for the solar thermal plant as a whole. Because the selection of the syster goals was based on competing in a given enargy application, they were determined by the characteristics of the competing energy sources. The price, availability, escalation rate, supply uncertainty, efficiency, and other factors of competing energy sources will determina the ultimate energy cost that is necessary for solar thermal to succeed in a given application. The systen goals are not a threshoid energy cost that solar thernal must achieve to allow initial sales. Rather, the goals represent a cost that could achieve significant market penetration.

Component goals were used to determine how solar thermal plants can meet the system goal. Component goals are performance and cost targets for the primary elements of a solar thermal plant (concentrators, receivers, etc.) and were selected based on considerations of component efficiency and cost improvements that could be attained through further research and development $(R \& D)$. The relationship between system and component goals is shown in Figure 2.1. 


\title{
System Goal Component Goals
}

\author{
$\mathbf{s} / \mathbf{k w h}=\left\{\begin{array}{l}\text { Concentrator } \\ \text { Receiver } \\ \text { Transport } \\ \text { Energy Conversion } \\ \text { Energy Storage } \\ \text { Balance of System } \\ \text { O\&M }\end{array}\right.$
}

FIGURE 2.1. Relationship Between System and Component Goals

For a given system goal, many alternative sets of component goals could satisfy the system energy cost goal. These alternative sets exist because of the many tradeoffs between component efficiency and cost and between component cost and perfornance. For example, a heat engine with moderate efficiency and low cost is an alternative to a high-efficiency/high-cost heat engine. Tradeoffs exist among goals for various components because a decrease in the cost/performance goal for one component allows the yoal for some other components to be increased without exceeding the energy cost goal for the system.

\subsection{SOLAR THERMAL APPLICATIONS}

Two system goals rather than one were required for the applications in this study because utility electricity and IPH represent not just different applications but also substantially different markets. The markets differ in terins of competing energy sources, econonic, financial, and regulatory considerations, and other factors. The basis for calculating the levelized cost was drastically different for each because of the differences in the competing energy sources and economic/financial factors of electricity and IPH applications. Therefore, the system cost goal (which is a levelized energy cost) cannot be directly compared between the two applications. A more detailed approach of using more than two separate system goals could have been considered (factoring in regional differences for utilities, differences by industry or differences by IPH application temperature, etc.). However, such 
an approach obviously would have greatly compounded the problem of goals development without necessarity increasing the usefulness of the final set of goals developed. The approach of having one system goal for electricity and one goal for IPH applications represented a compromise between consideration of important market differences among applications and the need for goals to be generally applicable for ease of use.

Unlike the system goals, component goals do not vary according to the appiication if the applications have the same quality of delivered energy. If the quality of delivered energy is the same, component perfomance and cost would be the same whether the component was used in a utility-electricity application or an IPH application. Component goals vary only for the dish systems, where the temperature range expected to be used for electricity producticn is much higher than the temperature range likely for typical IPH applications using dish systems. In this case, the actual component requirements would differ between the two applications, so different goals were appropriate.

Component goals were developed for the central receiver, dish, and trough technolocies. Central receiver systems use fields of heliostats (two-axis tracking mirrors) to reflect and focus the sun's energy on a central towermounted receiver. Dish systems also track the sun in two axes but have a distributed receiver mounted at the focal point of each concentrator. The trough technology uses the distributed receiver approach of the dish but tracks the sun in only one direction. The central receiver and dish technologies are expected to find long-tem applications for both electricity and IPH, whereas the trough system is expected to have long-term use primarily for IPH applications.

\subsection{GOALS DEVELOPMENT PROCESS}

An important aspect of developing the technology goals was recognizing the essential driving forces behind each type of goal. System goals represent the payoff for developing sclar thermal technology because the system goal defines the final delivered energy price of the solar thermal system. To maximize the payoff for technology development, the systern goals should be set as low as 
possible; the ideal situation would exist if the systen goals for solar thermal technology were economically superior to all other energy sources.

Component goals represent the path to achieving the system goal. As such, their most important characteristic is being judged as achievable. To maximize the probability of achieving the component goals, the goals should be set as low as possible (low performance-high cost). The opposite driving forces between systems and component goals naturally lead to sone iteration in developing goals; the desire for the lowest possible system goal must be balanced by component goals which are expected to be technically achievable. The set of goals selected must represent a compromise between minimizing the risks inherent in attaining the component goals and maximizing the potential payoff represented by the system goal.

For this project, both system and component goals were developed using a levelized energy cost (LEC) approach. With the LEC methodology, all relevant elements of an energy source cost are considered, including capital costs, operating costs, and return on investment. After the net present value of ail costs is assessed, an equivalent energy cost that is level (i.e., constant from year to year) is calculated over the plant's lifetime. The LEC approach was used to develop the technology goals because 1) it provides an economically correct approach to valuing revenues and expenses; 2) it has had significant use for past evaluations of solar thermal technology; and 3) it is a familiar technique to the electric utility industry.

An example of an LEC calculation is shown in Figure 2.2. The initial cash flows associated with the energy option over the operating life are first developed and then collapsed to a present value. The present value of all plant costs is then converted into an equivalent level annualized cost. The LEC is obtained by dividing the annualized cost by the plant's annual energy output (assuming the output is constant over time). The present value of ali the revenues collected by the LEC cost will exactly equal the present value of all the original cash flows.

The LEC calculations for technology goals were done on a constant dollar (also known as a real dollar) basis, which removes the effects of general inflation. The constant dollar approach results in energy costs that are 


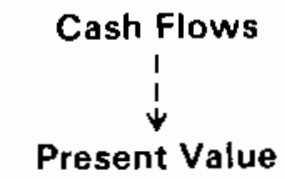

Annualized Cost

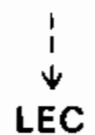

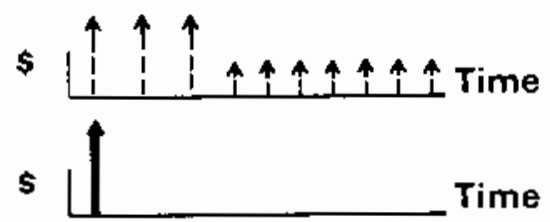

$s$ เ

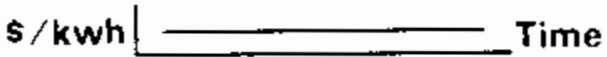

FIGURE 2.2. An Example LEC Calculation

steady over time when expressed in dollars of constant purchasing power. An alternative approach is to use nominal dollars (dollars of a particular year), assuming a general rate of inflation. Either approach will yield the same relative comparison of one energy alternative to another.

As described in the previous section, separate system goals were required for electricity and IPH applications. One reason for this is that the market differences between these applications require significantly different assumptions to be made in the LEC methodology, and different assumptions substantially inpact the result calculated. Because of those differences, the system yoals for these applications cannot be directly compared on a thermodynamic basis. While the $\$ 0.05 / \mathrm{kWe}$ system goal would seem to imply an achievable goal that is much lower than $\$ 9 / M B t u$, the differences in economic assumptions account for the higher IPH goal. The LEC methodology and assumptions used in the calculations are discussed in Appendix $A$.

The LEC calculations established the system goals for the energy sources that solar thermal must compete against. Component goals were established in an allocation process, where perfornance and cost tradeoffs of components were examined. The constraint in allocating the component goals was that the LEC of a solar thermal system must achieve the system goal. This approach lead to some iteration in the process of developing goals. An initial system goal must be developed and used to determine component goals. If the component goals achieved are judged to be unattainabie (or too easily attainable), the target competition used in developing the system goal must be redefined. 


\subsection{SYSTEM GOALS}

The system goal can be regarded as the payoff (market penetration) for developing solar thermal technology because achieving the system goal for an application would displace some of the energy sources currently used in the application. System goals are used to quantify the solar therinal system's overall performance and cost that are needed to obtain the desired payoff.

Because the selection of solar thermal system goals was based on competing in a given energy application, they were deterinined primarily by the characteristics of competing energy sources rather than by the characteristics of the solar thermal system. The competing energy sources define what is currently being accepted in the market, and they establish performance and cost characteristics that solar thermal must meet or exceed to be implemented. For competing energy sources, price, projected escalation rate, and efficiency are amony the key factors that deterinine the ultimate characteristics that solar thermal rust have to succeed in any given application.

System goals in this report were based on projected levelized energy costs of competing energy sources in the middle-to-late-1990's time frame. These goals do not represent a threshold energy cost that solar thermal must achieve to allow initial sales. Rather, the goals represent a cost that would be competitive with many energy sources and that could achieve significant market penetration, depending on the price increases which occur for conventional energy sources. Between now and the mid 1990s, solar thermal systems would be expected to be sold in many specific applications where an energy cost higher than the system goals is economically feasible. Near-term sales of solar therinal systems in highly valued applications will be vital to achieve the technology goals because significant production leveis (leading to economies of scale) in solar collectors will be an important element in achieving the component goals for concentrators and (in some cases) receivers. The systems goals developed for each application are discussed in the following sections.

\subsection{SYSTEM GOALS FOR ELECTRICITY}

Grid-connected electricity represents an attractive market for solar therinal technology. In 1983, U.S. electric power production was 2,341,000 
gigawatt-hours (7.9 quads at 3412 Btu/kWh), including power losses in transmission and distribution (DOE 1984C). The actual electric energy delivered to end users in 1983 totaled 7.3 quads (Hoitberg, Woods and Ashby 1984). The fuels consumed in electric energy production in 1983 totaled 24.9 quads, or roughly one-third of the total 74.1 quads of total U.S. energy consumption that year (Holtberg, Woods and Ashby 1984).

One of the primary ways that solar thermal could impact the electricity market is by supplying part of the additional capacity which will be required because of load growth and the retirement of existing capacity. In the summer of 1983, U.S. electric production capacity was over 596,000 MW (D0E 1984C). Many projections for demand growth for electric power range between $2 \%$ and $4 \%$ annually over the next 10 to 20 years. The Electric Power Research Institute (EPRI) has published both a high and low projection of additional capacity needs by the years 2000 and 2010 (Stahlkopf 1984). Under the low projections, 43,000 MW of new capacity will be needed by 2000, with an additional 211,000 MW required by 2010. Under the high projections in the study, 500,000 MW of new capacity will be needed by the year 2000, with an additional 511,000 MW required by the year 2010 . These projections for additional capacity requirements are net of currently planned capacity through 1991.

Currently, the principal sources of energy for producing electricty are petroleum, gas, coal, nuclear, and hydro. Actual energy consumption from these resources in 1983 and a projection for the year 2000 are shown in Table 3.1 (Holtberg, Woods and Ashby 1984). Between now and the end of the century, coal is projected to increase its dominance as the principal fuel consumed to produce electricity. Nuclear power is expected to increase its share to become the second largest electric power energy source, whereas the importance of petroleum, gas, and hydro is expected to decline. The other sources shown in Table 3.1 include all forms of renewables, which are projected to begin making a more significant contribution by the year 2000 .

Solar thermal plants for producing electricity could be designed over a wide range of sizes and capacity factors. The dish technology has the capability to have an economic module size of several hundred kWe, with systems of hundreds of the possible by combining modules. Central receiver systems could 
TABLE 3.1. Energy Consumption for the Production of Electricity

\begin{tabular}{|c|c|c|c|c|}
\hline & \multicolumn{2}{|c|}{1983} & \multicolumn{2}{|c|}{2000} \\
\hline & Quads & $\begin{array}{l}\text { Percent } \\
\text { of Total }\end{array}$ & Quads & $\begin{array}{l}\text { Percent } \\
\text { of Total }\end{array}$ \\
\hline Petroleum & 1.5 & 6.0 & 1.5 & 4.0 \\
\hline Gas & 3.0 & 12.0 & 2.6 & 7.0 \\
\hline Coal & 13.2 & 53.0 & 21.7 & 58.0 \\
\hline Nuclear & 3.2 & 12.9 & 6.6 & 17.6 \\
\hline Hydro & 3.8 & 15.3 & 3.9 & 10.4 \\
\hline Other & 0.2 & 0.8 & 1.1 & 3.0 \\
\hline Total & 24.9 & 100.0 & 37.4 & 100.0 \\
\hline
\end{tabular}

range from several MW to over $100 \mathrm{MW}$ in a single plant module. Attaining intermediate load capacity factors of 0.4 to 0.5 for plants using thermal storage appears to be technically and economically feasible. Solar thermal plants could easily operate in a solar-only mode, although hybridization may also be an attractive option in some cases.

In selecting the electric system goals, the plants were assumed to be utility-owned and grid-connected. Several other applications, such as remote applications or third-party ownership of the plants, could potentially represent significant markets for solar thermal technology, but were not considered in developing the system goals.

One of the key questions in developing goals for electricity applications was identifying the technologies that solar thermal should compete with. Premium-fueled (oil and natural gas) plants were one potential target because they use expensive and scarce fuels. Whereas solar thermal could be expected to have an impact on premium-fueled plants, they do not form a good basis for system goals. Premium-fueled plants are expected to be gradually phased out over time (because they are expensive), so the amount of plant capacity that solar thermal could replace may not be large. As Table 3.1 shows, the single type of conventional plant that is most expected to supply a large fraction of electricity production and to grow in use over time is the coal-fired power plant, as indicated in Table 3.1. Coal plants are expected to be one of the 
most economical sources of electric power in the next several decades, assuming no new major environmental controls are required.

System goals for electricity were developed using as the competing technology energy cost estimates from coal-fired power plants of intermediate load. By choosing one of the lowest energy-cost technologies as the basis for setting system goals, solar thermal could expect to be competitive with several other alternatives if the goals are met. The energy cost from coal-fired power plants was used as the target for system goals to indicate that the cost is a reasonable target for widespread adoption of solar thermal energy, not to indicate that solar thermal could replace a large amount of coal-fired capacity.

Four performance/cost assumptions (in addition to general economic assumptions) affected the estimation of energy costs from conventional power plants: 1) the performance of the fossil fuel system, 2) the price of the fuel in the first year of operation (between 1995 and 2000), 3) the real price escalation rate of the fuel over time, and 4) the capital and 0\&M costs for the facility. Of these assumptions, the initial fuel price, price escalation rate, and projected capital costs had both the largest impact on the energy cost estimate and the greatest uncertainty. To set goals, Pill addressed the uncertainty in estimating the future LEC from a coal-fired power plant by using input data from several studies to characterize an expected range of energy costs.

To estimate the energy cost of a coal plant, the following information was used: 1) the basic plant characteristics (such as capital cost, heat rate, fuel cost, etc.), as reported in reference reports, and 2) the levelized cost methodology and assumptions used throughout the goals development process. The range in the basic performance and cost assumptions used in the energy cost calculations for future coal-fired power plants is shown in Table 3.2. Costs from the reference reports were updated to 1984 price levels to be consistent with the other calculations for the technology goals. The levelized cost methodology used was described in Chapter 2 and in more detail in Appendix $A$.

For the coal plants from each of the reference studies, the impact of capacity factor on the LEC was analyzed. The resulting LEC estimates of the coal plant over a range of capacity factors are shown in Figure 3.1. For 
TABLE 3.2. Range of Coal Plant Characteristics Used in Estimating Levelized Energy Cost (all costs in 1984 dollars)

\section{Plant Characteristic}

Plant Size

Net Annual Heat Rate

Capital Cost

Annual 0\&M Cost

First Year Coal Cost (1990-1995 time frame)

Real Price Escalation Rate for Coal

\begin{tabular}{c} 
Range \\
\hline $550-1200 \mathrm{MWe}$ \\
$9650-10200 \mathrm{Btu} / \mathrm{kWh}$ \\
$\$ 1000-1900 / \mathrm{kWe}$ \\
$\$ .0039-.0065 / \mathrm{kWh}$ \\
$\$ 1.6-2.8 / \mathrm{MBtu}$ \\
$0.015-0.029$ Annual
\end{tabular}

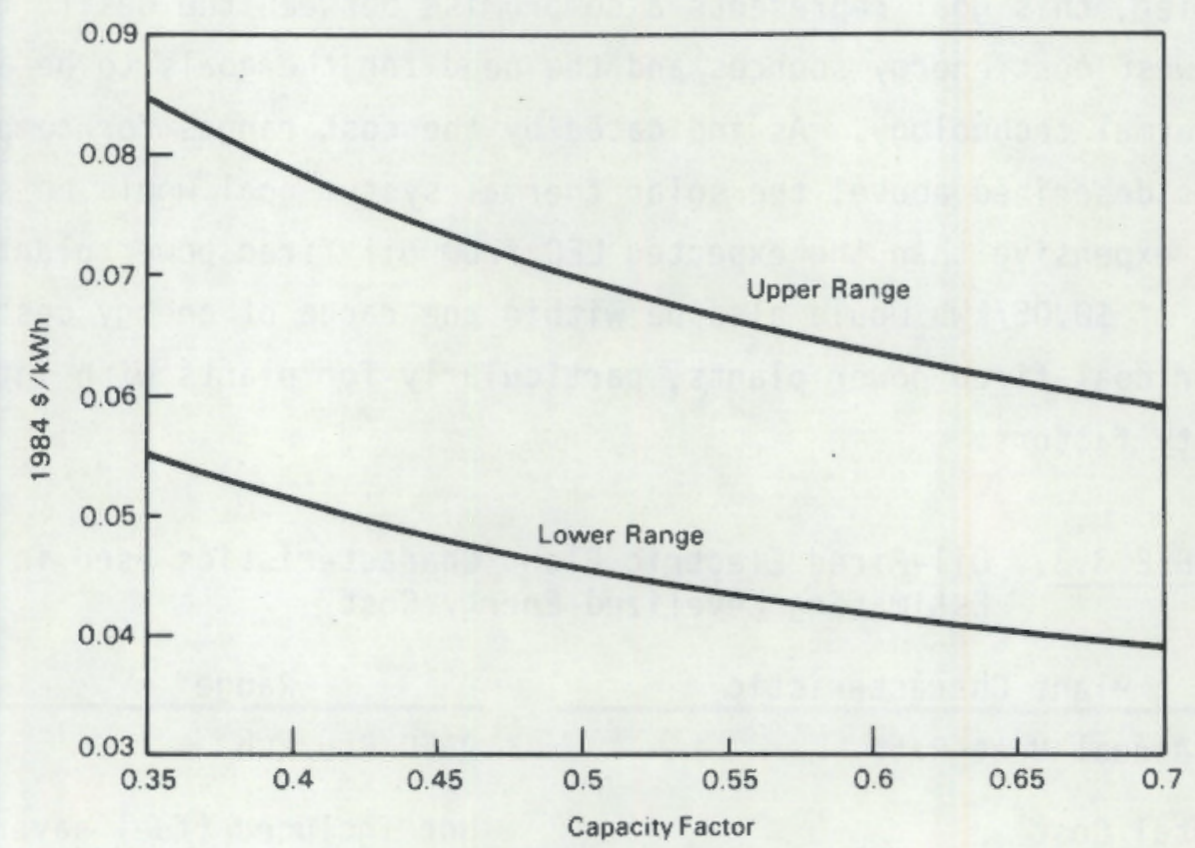

FIGURE 3.1. Range of Projected Energy Costs for Coal Plants

baseload plants, the calculated LEC ranged from $\$ 0.04 / \mathrm{kWh}$ to over $\$ 0.06 / \mathrm{kWh}$. For intermediate load plants over the capacity factor range of 0.4 to 0.5 , the calculated LECS ranged from slightly under $\$ 0.05 / \mathrm{kWh}$ to nearly $\$ 0.08 / \mathrm{kWh}$. Appendix B provides details of the calculations and the sources used.

To compare energy cost calculations for coal plants, the price of energy from a oil-fired power plant was also calculated. For this calculation, the solar thermal plant was assumed to compete against the oil-fired plant as a 
fuel saver (i.e., a solar thermal plant would be used to avoid fuel expenses for an existing oil plant rather than to avoid construction of a new petroleum plant). Therefore, the capital cost of a oil-fired plant is not included in the energy cost calculation. Values used in calculating the LEC are shown in Table 3.3. The oil-fired plant characteristics and the fuel escalation rate assumption were taken from the EPRI's Technical Assessment Guide (1982). The initial fuel price projections were taken from middle-case projections in a DOE estimate (DOE/EIA 1983). The LEC calculations yielded $\$ 0.09 / \mathrm{kWh}$ for the highsulfur fuel case and $\$ 0.11 / \mathrm{kWh}$ for the low-sulfur fuel case.

The solar thermal technology system goal selected was $\$ 0.05 / \mathrm{kWh}$. As described earlier, this goal represents a compromise between the desire to compete with the lowest cost energy sources and the need for the goals to be achievable by solar thermal technology. As indicated by the cost ranges for competing technologies described above, the solar thermal system goal would be significantly less expensive than the expected LEC from oil-fired power plants. The system goal of $\$ 0.05 / \mathrm{kWh}$ would also be within the range of energy costs expected for coal-fired power plants, particularly for plants with intermediate load capacity factors.

TABLE 3.3. 0il-Fired Electric Plant Characteristics Used in Estimating Levelized Energy Cost

Plant Characteristic

Net Annual Heat Rate

Capital Cost

Annual $0 \& M$ Cost

First Year Residual Fuel Cost

(1990-1995 time frame)

Low Sulfur Fuel

High Sulfur Fuel

Real Price Escalation Rate for Fuel

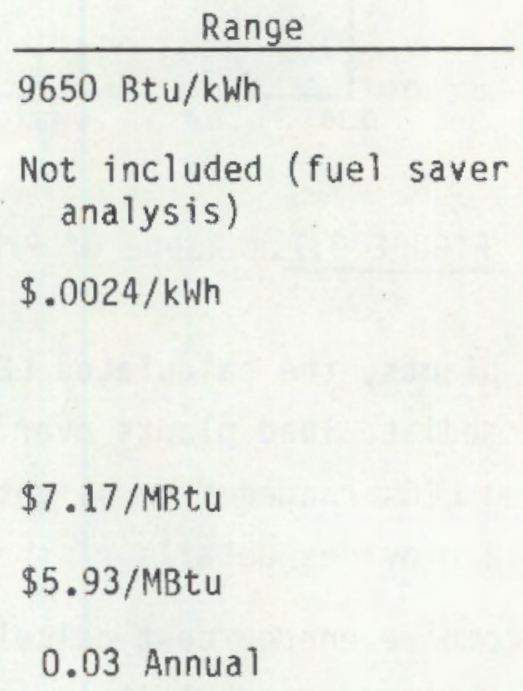




\subsection{SYSTEM GOALS FOR INDUSTRIAL PROCESS HEAT}

Industrial process heat (IPH) represents a large potential market for solar thermal technology. According to DOE estimates, U.S. industrial energy consumption totaled 27.2 quads in 1983 (DOE 1984a). Process heat did not account for the entire estimate because this estimate includes both electric conversion losses and fuels used as feedstocks. The Gas Research Institute estimates industrial fuels consumption for heat and electricity generation (excluding electric conversion losses and fuel used as feedstock) at 17.6 quads (Holtberg, Woods and Ashby 1984). Overall industrial energy consumption is expected to grow at roughly $2 \%$ annually between now and the end of the century (Holtberg, Woods and Ashby 1984; DOE 1984a).

The relative importance of the various energy forms used by industry in 1983 and projections for future use are shown in Table 3.4 (Holtberg, Woods and Ashley 1984). Consumption of all energy forms is expected to increase by the end of the century, with coal use increasing the most. The largest fuel uses in both the current market and the projections for the year 2000 are petroleum and natural gas.

Solar thermal plants could be used to produce industrial process heat over a wide range of temperatures and therefore could compete with many different fuels. Solar thermal plants could be designed over a wide range of sizes,

TABLE 3.4. Industrial Fuel and Power Consumption Estimates(a)

\begin{tabular}{|c|c|c|c|c|}
\hline & \multicolumn{2}{|c|}{1983} & \multicolumn{2}{|c|}{2000} \\
\hline & Quads & $\begin{array}{l}\text { Percent } \\
\text { of Total } \\
\end{array}$ & Quads & $\begin{array}{l}\text { Percent } \\
\text { of Total }\end{array}$ \\
\hline Petroleum & 4.7 & 26.7 & 5.8 & 23.4 \\
\hline Gas & 6.1 & 34.7 & 7.8 & 31.5 \\
\hline Coal & 1.5 & 8.5 & 3.5 & 14.1 \\
\hline Electricity & 2.6 & 14.8 & 4.0 & 16.1 \\
\hline Renewables & 2.7 & 15.3 & 3.7 & 14.9 \\
\hline Total & 17.6 & 100.0 & 24.8 & 100.0 \\
\hline
\end{tabular}

(a) Does not include fuels consumed as feedstocks or electrical energy conversion losses. 
from several hundred kWt to hundreds of MWt. While storage can be used to extend the operating time and flexibility of solar thermal IPH systems, it is likely that most applications will be operated in a hybrid mode (where solar heat is used when available to displace fossil fuel) to maintain 24-hour availability of the industrial energy source.

The IPH system goals assumed that the solar thermal plant would be owned by the industrial energy user and that the system would have a fossil-fired backup. With a fossil backup, the benefits of the solar thermal system would be in fuel savings only and do not include any capital cost savings for the fossil fuel system.

The competing fuels assumed for establishing IPH system goals were natural gas and 0il. As shown in Table 3.4, these fuels constitute the largest fraction of the market for industrial energy-use applications. Unlike the electricity applications, coal was not targeted as a competing fuel for IPH applications. Because the required return on investment for energy investments in the industrial market is higher than for the electric utility market, solar thermal most likely will be unable to successfully compete with coal in IPH applications.

Three performance/cost assumptions affected the LEC calculations used developing IPH system goals: 1) the performance of the fossil fuel system, 2) the price of the fuel (in the first year of operation, between 1995 and 2000), and 3) the real price escalation rate of the fuel over time. Of these three assumptions, the initial fuel price and price escalation rate had the largest impact on the goals and the greatest uncertainty. The performance assumption was necessary to convert from a purchase price for fuel to a delivered price for the thermal energy actually absorbed by the process stream, and accounted for stack losses, combustion inefficiencies, etc. An efficiency of $85 \%$ was assumed in all calculations as reasonable for fossil fuel systems in the mid-1990s over a wide range of temperatures.

The primary sources for fuel prices used in developing IPH system goals were projections in support of the National Energy Policy Plan (NEPP) (DOE 1983) and projections by the Energy Information Administration (EIA) (DOE/EIA 1983). The NEPP estimates were the primary source for determining system goals 
because they cover a time horizon through the year 2010. The EIA projections extend only through 1990 but were used to verify fuel prices through that time frame. In using NEPP estimates to calculate LECs, the fuel cost projections for each year between 1990 and 2010 were used explicitly. The comparative estimates calculated with the EIA projections used the 1990 fuel cost estimate combined with various assumptions of real fuel escalation rates over the period of 1990-2010.

Industrial price forecasts from the NEPP projections for residual fuel from 1990 to 2010 are shown in Figure 3.2 for the three scenarios (base-case estimates, high world oil price and low world oil price) considered in the source (DOE 1983). The costs shown in Figure 3.2 have been updated to 1984 dollars from the 1982 dollar estimates in the source. The results of a levelized cost calculation of delivered energy (accounting for conversion efficiency and using a linear interpolation for fuel costs between the five year estimate points) are shown in Figure 3.3.

Industrial price forecasts (updated to 1984 dollars) from the NEPP projections for distillate fuel from 1990 to 2010 are shown in Figure 3.4. Price

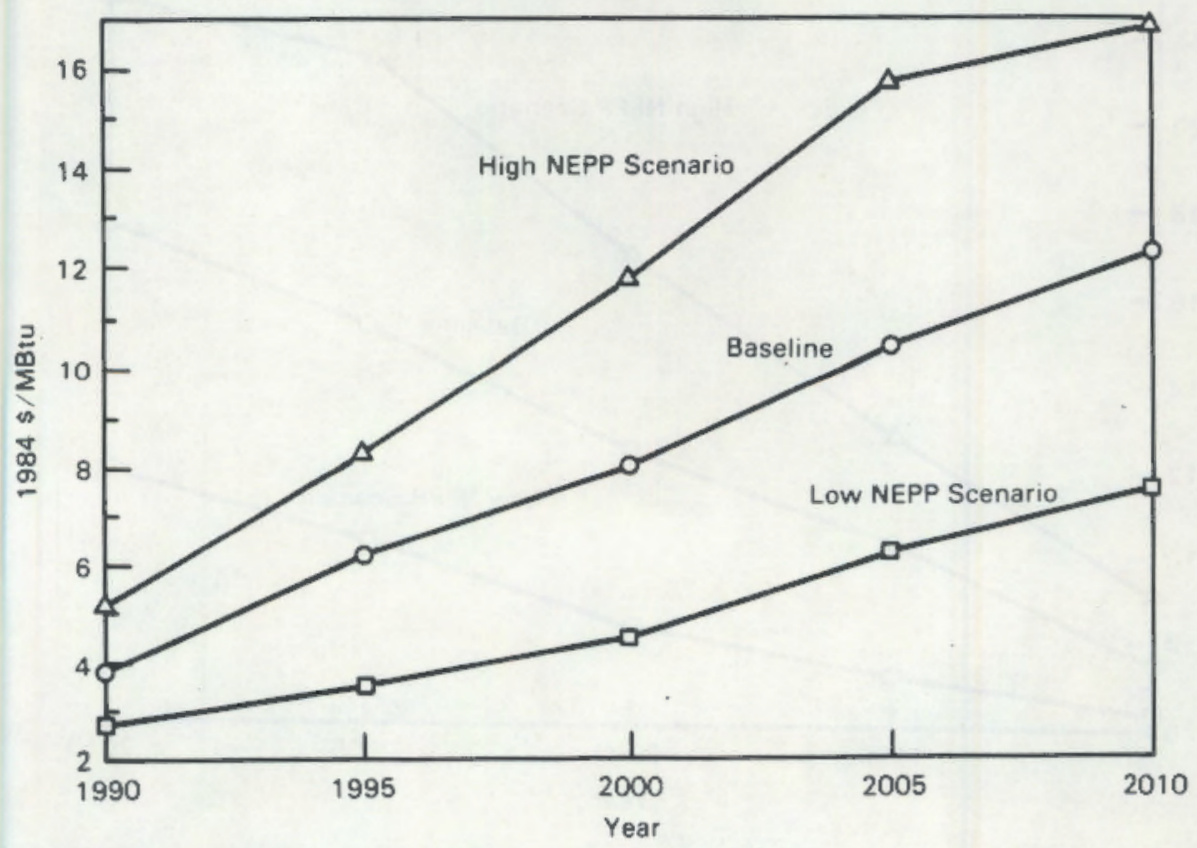

FIGURE 3.2. Residual Price Projections in Support of the National Energy Policy Plan (1984 \$) 


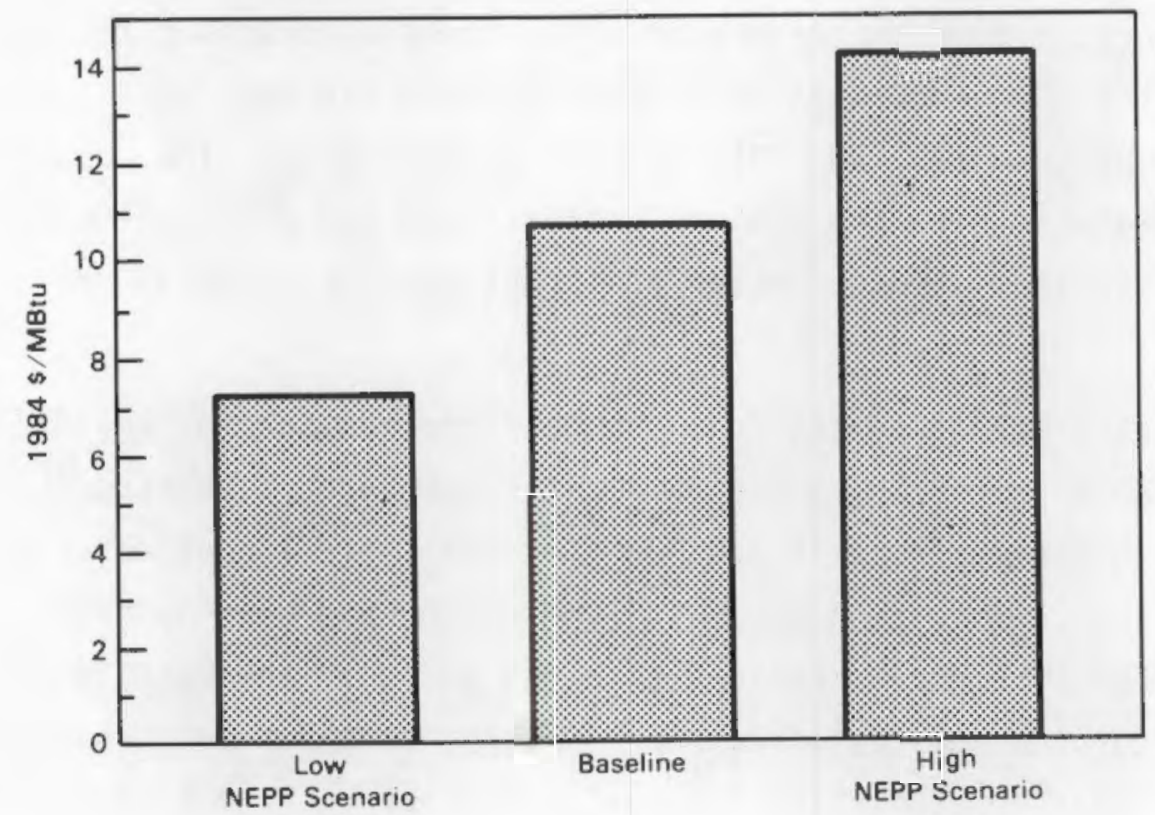

FIGURE 3.3. Residual Projections in Support of the National Energy Policy Plan (levelized energy cost)

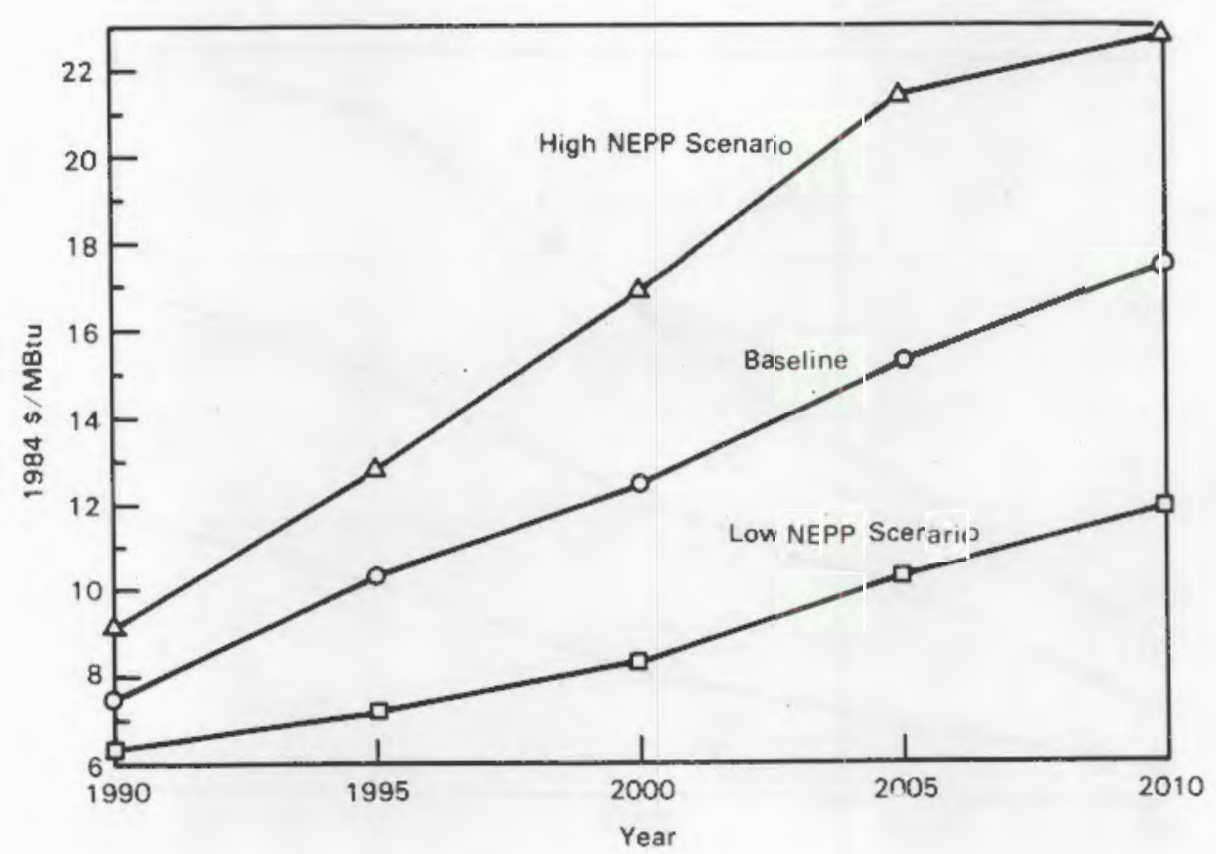

FIGURE 3.4. Distillate Price Projections in Support of the National Energy Policy Plan (1984 \$) 
projections for distillate fuel are all generally higher than for residual fuel because distillate is a more refined and expensive fuel. The results of a levelized cost calculation of delivered energy for distillate fuel are shown in Figure 3.5. (The calculation was performed in the same manner as for the residual fuel case.)

Industrial price forecasts of natural gas (updated to 1984 dollars) from the NEPP projections from 1990 to 2010 are shown in Figure 3.6. Price projections for natural gas do not follow the exactly the same trends as the projections for residual or distillate fuels because supply and demand factors for natural gas differ from those for oil. The results of a levelized cost calculation of delivered energy for natural gas are shown in Figure 3.7. (The calculation was performed in the same manner as for the residual fuel case.)

A system goal of $\$ 9 /$ MBtu was selected for solar thermal IPH applications, based on the above analysis of the projected LEC of oil and natural gas and on considerations concerning achievable component goals. This energy cost would

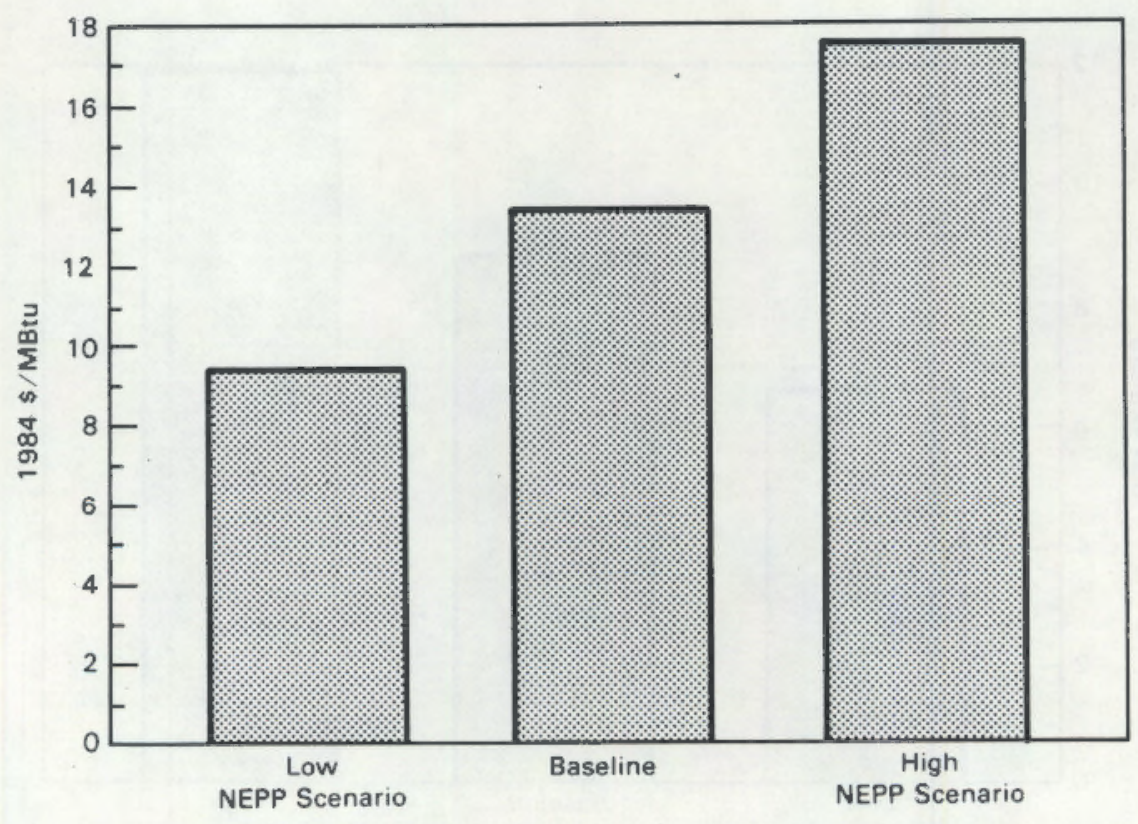

FIGURE 3.5. Distillate Projections in Support of the National Energy Policy Plan (levelized energy cost) 


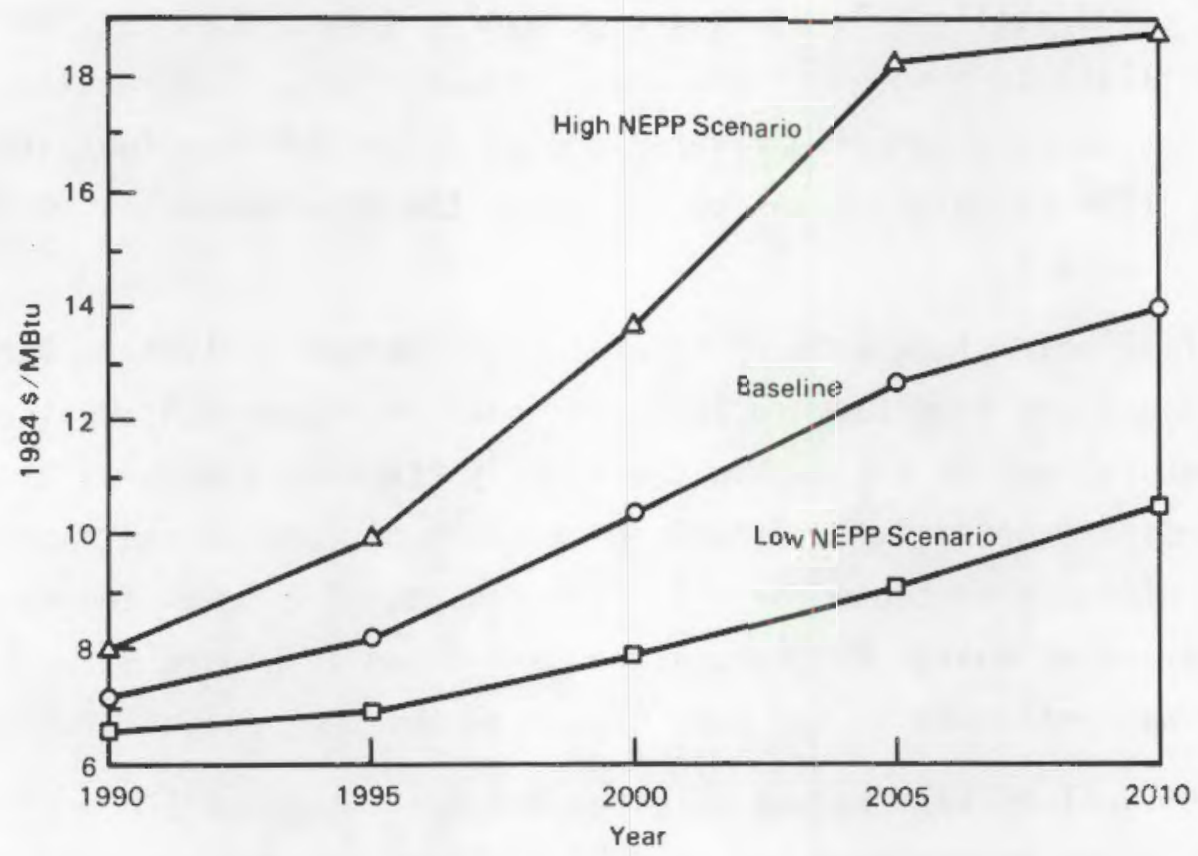

FIGURE 3.6. Natural Gas Price Projections in Support of the National Energy Policy Plan (1984 \$)

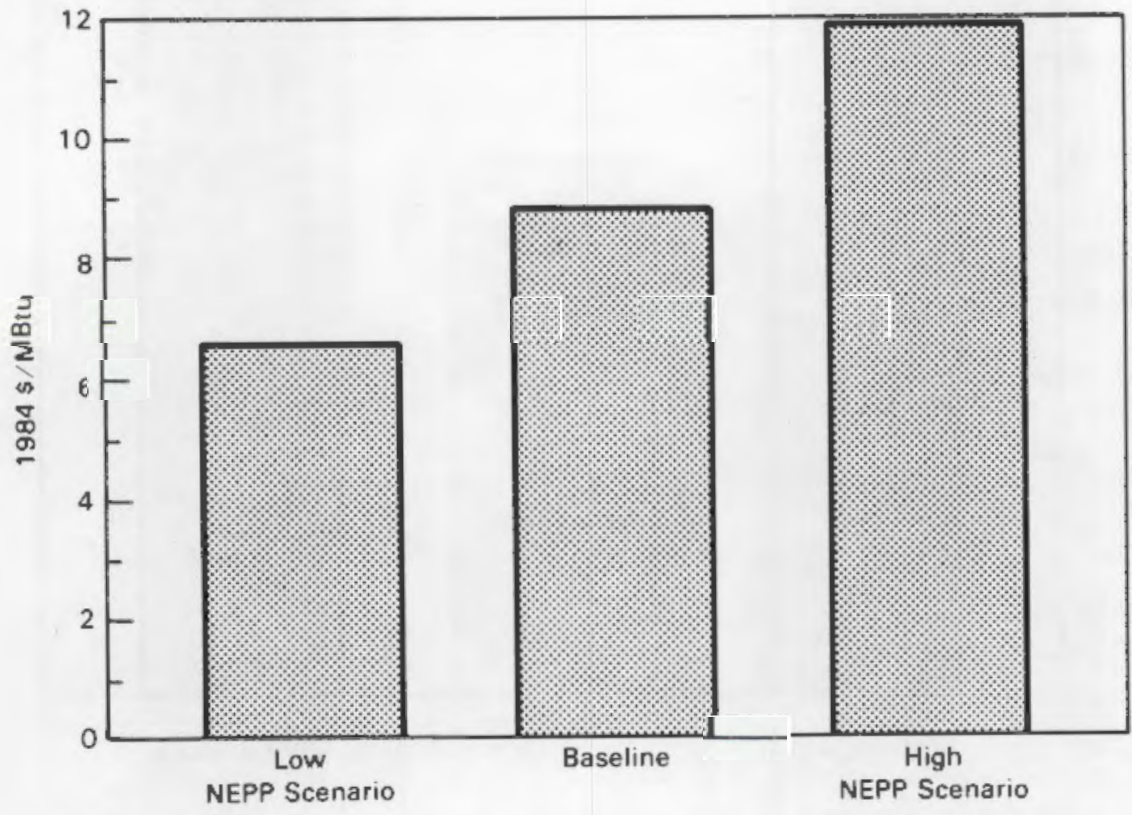

FIGURE 3.7. Natural Gas Projections in Support of the National Energy Policy Plan (levelized energy cost) 
be competitive with the base-case scenarios for residual fuel, distillate fuel and natural gas in the NEPP projections. The system goal would also be competitive with the NEPP low-case projections for distillate fuel.

The calculations based on NEPP projections are conservative in that they are for the years 1990-2010 because the NEPP projections only extend to the year 2010. The time frame for the solar thermal system goals is the middle to late 1990s, conceivably 10 years after the initial projections for the NEPP. If the LEC calculations were carried out for the appropriate time frame, fuel prices would be higher throughout the analysis period, and the IPH system goal would be even more competitive with the projections.

The LEC using the 1990 EIA estimates for residual fuel prices was compared to the LEC using NEPP estimates to investigate the required real rate of fuel escalation needed to meet or exceed the IPH system goal (DOE/EIA 1983). In this analysis, the EIA 1990 fuel price was used as an initial fuel price, and a real rate of inflation was assumed to calculate an LEC. The plant was assumed to begin operations in 1995 (i.e., 5 years of fuel price escalation are added to the initial 1990 fuel price before operations begin). LEC calculations using the EIA projection for residual fuel are shown in Figure 3.8. For both the base case and the high oil price case, the system goal is competitive with residual fuel at any real fuel escalation rate above $0.5 \% /$ year. Even for the low oil price scenario, the system goal is competitive with residual fuel if the real escalation rate is between $2 \%$ and $2.5 \%$ per year.

Similar LEC calculations using EIA projections for natural gas are shown in Figure 3.9. To clarify a potential point of confusion in the figure, it should be noted that the lowest EIA natural gas projection in 1990 is for the base-case oil price scenario. Both the low $0 i 1$ price scenario and the high oil price scenarios have higher predictions for the price of natural gas. For the base-case scenario, the system goals would be competitive with natural gas if the real escalation rate for natural gas were $2 \%$ per year or higher. For either of the other two scenarios, the system goal would compete with natural gas even at real escalation rates of $0.5 \% /$ year.

In summary, the system goals for solar thermal IPH applications were derived substantially from energy cost projections done in support of the 


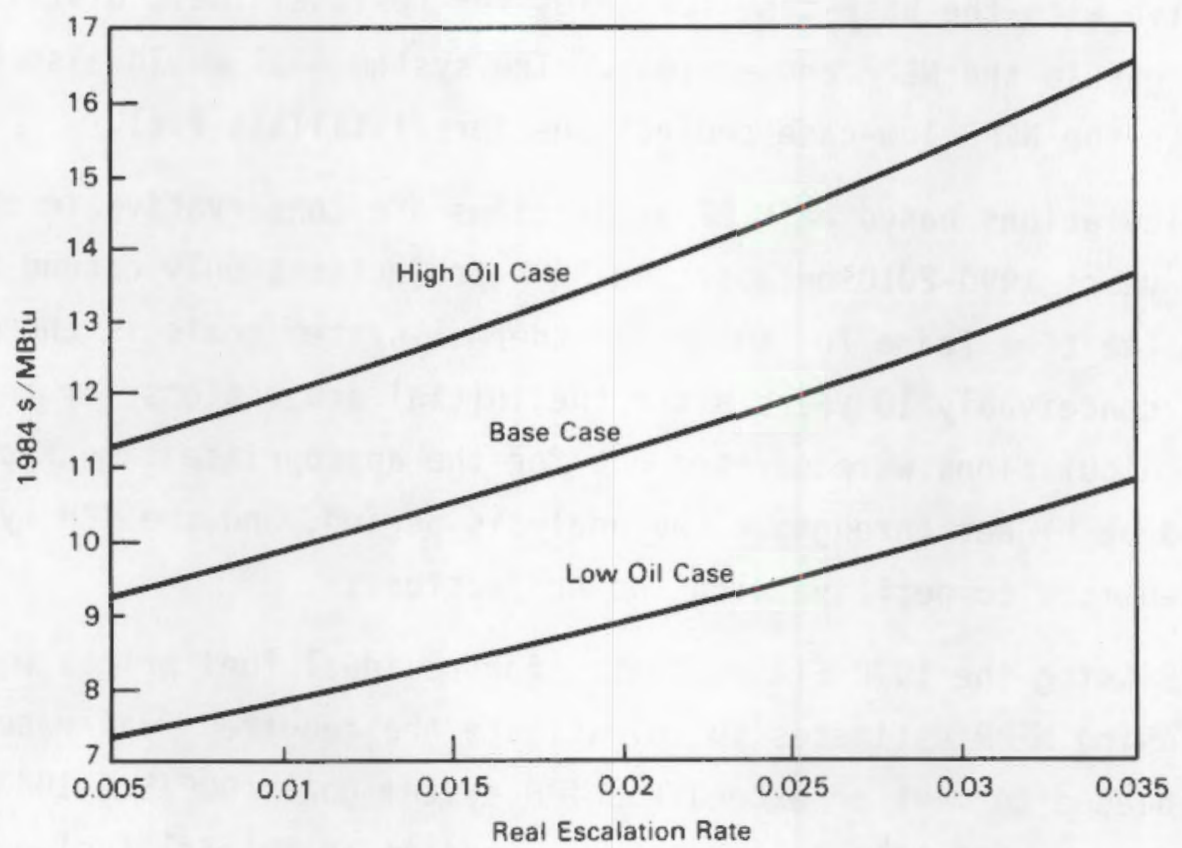

FIGURE 3.8. LEC Using 1990 EIA Projections (residual fuel 1995 start date)

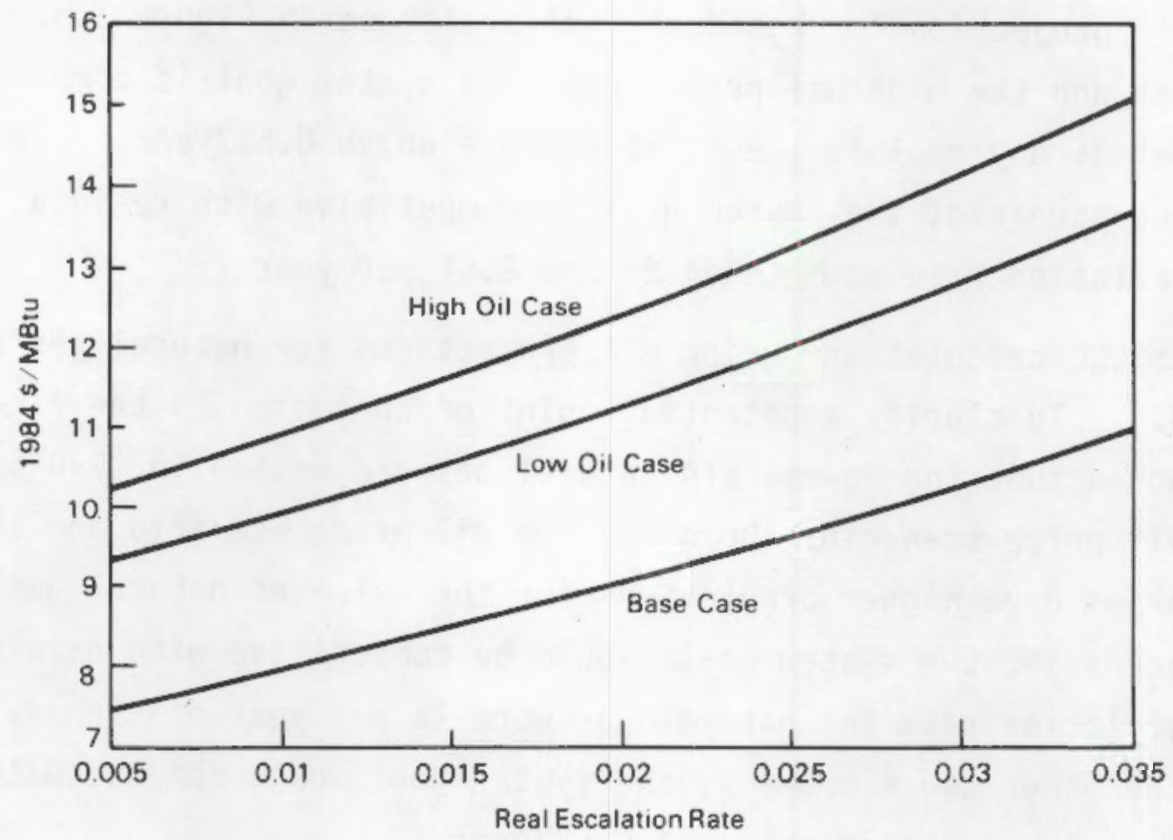

FIGURE 3.9. LEC Using 1990 EIA Projections (natural gas 1995 start date) 
NEPP. The system goal selected was $\$ 9 / M B t u$ for the levelized cost of delivered thermal energy and is competitive with what are currently perceived to be either baseline or conservative (i.e. low perceived price increases) projections of fossil heat in the middle-to-late 1990s. 
$\bullet$ 


\subsection{COMPONENT GOALS}

Component goals were selected for eight areas of a solar thermal plant: concentrators, receivers, energy transport, energy storage, energy conversion, balance of plant, installed system cost, and operation and maintenance (O\&M) costs. In this chapter the results of the component goal development are presented. In Section 4.1 , the cost and performance definitions related to componen: goals are discussed. In Section 4.2, the approach used to develop the component goals is described. Finally, Section 4.3 lists in tabular form and briefly describes the component goals and supporting references.

\subsection{COST AND PERFORMANCE DEFINITIONS}

This section contains definitions related to the component yoals and explains the method used to calculate a system-level energy cost.

\subsubsection{Equipment and Cost Definitions}

A11 costs are reported in 1984 dollars. Because these costs are for systems sol 1 commercially, they include normal manufacturers' and contractors' profits. Because all component costs are for installed equipment, they include manufacturers' selling price, shipping, and field installation.

The activities and equipment included within each of the eight areas are briefly Jefined and described below.

Concentrators include all of the equipment and activities necessary to have an operating concentrator field, with the exception of the master control system. Concentrators include the purchased concentrator itself, field construction activities (foundations, pedestals, etc.), power wiring, control wiring, and any distributed control equipment located in the concentrator field (i.e. equipment to control small blocks of concentrators).

Receivers consist of the equipment to convert optical energy into thermal energy, structural support for this equipment, and associated items for reducing losses from the equipment. This category would include receiver heat exchange surfaces, receiver structure (cavity or support structure), receiver 
structural support (towers in the case of a central receiver system), cover glasses, optical coatings, and flow control equipment that is integral to the receiver.

Transport may be either thermal transport or electrical transport. Thermal transport consists of all equipment required to convey the heat collected at the receiver (or receivers for distributed systems) to a centralized point. This would typically include piping, pumps, valves, insulation, surge and storage tanks (storage tanks related to freeze protection rather than thermal storage), and the transport media. For systems which also incorporate thermal storage, the amount of transport media which would fill the receiver and piping network is allocated to transport. In distributed systems, the riser and downcomer are included in thermal transport. Electrical transport consists of all the equipment required to convey the electrical energy generated at several distributed sites in the collector field to a centralized point. The primary equipment in electrical transport would be field wiring.

Storage is aimed at themal storage; electrical energy storage was not considered in developing the goals. Storage equipment includes everything required to save thermal energy for later use. This equipment includes storage tanks, insulation, storage circulation equipment (pumps and piping required due to presence of thermal storage), storage medium, and input heat exchangers.

Conversion includes all of the equipment to convert the thermal energy collected in the receiver to electrical energy. Conversion is considered for electricity applications oniy. Equipment in the conversion subsystem includes the heat engine, generator, input heat exchangers for transferring heat from the thermal transport or storage working fluid to the heat engine working fluid), integral controls, integral piping and flow equipment, and heat rejection equipment.

Balance of plant (BOP) includes the significant cost items for plant equipment and facilities that are not included in the above categories. Typical items in BOP are land, initial site improvements, plant buildings (such as control buildings, maintenance buildings, and turbine buildings), master control systern, initial inventory of spare parts, and plant service 
facilities. For the IPH systems, the BOP also includes the output heat exchangers for transferring heat from the collector field or thermal storage into the process fluid.

The installed system cost is the total installed cost for the solar thermal system. The installed system cost includes the costs for the above categories plus the costs for indirects and contingencies. Both indirects and contingercies are estimated assuming that several previous plants have been built. Indirects and contingencies are estimated at similar levels as they would be for conventional power plants built today. Indirect costs include plant design, architect-engineer's fee, plant startup, temporary construction facilities, and general plant construction activities that are not allocated to any one of the above categories. Contingency reflects a standard allowance for cost increases due to unforeseen events such as weather, equipment supply problems, labor difficulties, etc. The contingency assumes that only a small degree $o^{*}$ cost uncertainty is present in the design because several plants have been built previously.

O\&M costs are annual costs associated with operating the plant and providing routine maintenance. These costs include direct and overhead costs for plant personnel, supplies, routine contracted maintenance on equipment, and annua? equipment replacement/repair costs. Major repair costs that would be incurred infrequently over the plant's life (for example, overhaul costs for distribuzed engines with a lifetime of 5 years) are also included in operations and maintenance on an average annual cost basis (cost per incident/years between incidents).

\subsubsection{Perforinance Assumptions}

The performance assumptions used in developing the solar thermal technology goals included both peak and annud performance. The peak performance assumptions were used only in calculating $\$ / \mathrm{kW}$ values. Therefore, those assumptions are not critical to the goals development because they only affect the units that certain goals were expressed in, not the goals themselves. The annual performance goals directly affected the calculation of levelized energy cost (because they determine the plant energy output) and therefore were very important to the development of goals. 
The annual efficiency values in the component goals were defined for a location similar to Barstow, California. Barstow was chosen because it is the site of the 10-MWe central receiver power plant that is currently undergoing operational testing. A component's average annual efficiency is defined as the tota? energy output from a component over a one-year period divided hy the total energy input (or potential) to the component over the same period. The annual efficiency is lower than peak efficiency because of the effects of such factors as solar position, insolation level, wind, ambient temperature, nighttime cooldown, etc. Annual performance definitions for each of the major subsystems are given below.

Concentrator performance includes all losses from the time immediately before the insolation strikes the concentrator surface to the time immediately before the concentrated energy strikes the receiver (either the receiver cover giass or receiver heat transfer surface). To calculate the total energy potential to the concentrator system, the product of the annual direct normal insolation is multiplied by the concentrator aperture area. With this definition, cosine losses, tracking errors, etc. must be included in calculating concentrator efficiency. Efficiencies included in the concentrator system include yeometric optics (cosine losses, blocking and shading, atmospheric attenuation), glass reflectivity, reflectivity degradation (due to dirt and long-term permanent losses), solar tracking errors, and receiver tracking errors.

Receiver performance includes losses from the time that flux strikes the receiver control volume (the receiver aperture, cover glass or heat transfer surface) until the thermal energy is transferred away from the receiver in a working fluid. The total energy potential to the receiver is the annual flux delivered from the concentrator field. Receiver losses include reflective losses and thermal losses due to radiation, convection, and conduction. An important aspect in characterizing annual performance is that receiver thermal losses continue even in no-insolation periods until the receiver reaches ambient temperature.

Transport performance in thermal transport subsystems includes losses from the time thermal energy is absorbed in the working fluid at the receiver until the thermal energy is delivered to storage or energy conversion. The total 
input energy to the thermal transport system is the annual energy absorbed by the working fluid in the receiver. Losses included in the thermal transport system consist of heat losses. Parasitic losses from pumping power requirements and losses from heat tracing are accounted for separately. For electricity applications, transport parasitics and electric heat tracing are accounted for as parasitic loads on the energy conversion subsystem and therefore are included in its efficiency. For IPH applications, electric energy is purchased (rather than being a parasitic) and does not appear in the efficiency, although it should be included in the plant O\&M cost. In some cases parasitic loads may actually add more thermal energy to the transport fluid than will be lost in a year due to themal losses. In these cases the annual efficiency of the transport system would be reported as 1.0 (rather than a value graater than 1), although the extra thermal energy can be accounted for in the pant thermal andysis. For electric energy transport systems, the efficiency is calculated from the losses among all distributed generators and the poin: of energy centralization. The total energy input for an electric energy tansport system is the annual energy output from all distributed generators.

Storage performance in thermal storage subsystems includes losses from the time thermal energy is delivered to the input heat exchanger (or storage tank itself if an input heat exchanger is not required) until energy is removed through the output heat exchanger. The total input energy to the thermal storaye system is the annual energy delivered by the transport system to the storage systiem (note that in some designs not all energy from the transport system will go through storage). Losses in the storage system consist of thermal losses from storage tanks and in heat exchangers. Parasitic losses from pumping power requirements and losses from heat tracing are accounted for separately. For electricity applications, transport parasitics and electric heat tracing are accounted for as parasitic loads on the energy conversion subsystem and therefore are included in its efficiency. For IPH applications, electric energy is purchased (rather than being a parasicic) and does not appear in the efficiency, although it is included in the plant 0\&M cost. For electric energy storage systems, the efficiency calculated includes losses from AC/DC conversion and net efficiency in battery storage. The total energy input for an 
electric energy transport system is the annual energy output from all distributed generators that is input to storage rather than being directly output to the grid.

Conversion efficiencies include all losses due to the thermodynamic performance of the heat engine and heat rejection equipment, generator efficiency, and plant parasitics. The total energy available to the conversion system is the annual energy delivered to the heat engine working fluid from the transport and storage subsystems. All plant annual parasitic power loads should be subtracted from the gross power produced by the conversion subsystem to obtain a net annual power production figure for calculating the conversion efficiency. Conversion efficiencies do not apply to IPH applications.

Balance-of-plant systems do not have efficiencies associated with them; all plant efficiencies are captured in the above categories.

As mentioned earlier, estimates of plant peak performance were only required for reporting component cost goals where $\$ / \mathrm{kW}$ units were desired. Peak power in a solar thermal plant can be defined by two other methods. The first method is to base the peak capacity on the nameplate design of the plant. This is easy to conceptualize in the case of a central receiver electric plant; the turbine will have a maximum peak rating (such as $100 \mathrm{MW}$ ) which becones the peak rating for the plant. This approach can create a communication problem, however. As the plant capacity factor increases, costs for the system in terms of $\$ / \mathrm{kW}$ also increase (costs increasing while $\mathrm{kW}$ rating is held constant), making the plant appear is less economical than a plant with a lower capacity factor and lower $\$ / \mathrm{kW}$ cost. The second method to specify peak capacity for solar thermal plants according to the peak collector field output. The second approach was used in reporting the component goals because it eliminates the problem of comparing values for plants with different capacity factors. For electric systems, reporting costs in this way means that the kwt rating of the conversion equipment is normalized to the peak thermal capacity of the receiver.

Performance calculations used in determining plant peak capacity and plant annual energy output apply equally to IPH and electric applications. For peak power calculations, a peak insolation level of $0.95 \mathrm{kWt} / \mathrm{m}^{2}$ is assumed. The 
peak plant output used in developing $\$ / \mathrm{kW}$ costs is then simply the total peak insolation $10.95 \mathrm{kWt} / \mathrm{m}^{2}$ multiplied by the concentrator field area) multiplied by the efficiency train of all plant components.

Plant annual energy is calculated in a similar manner as the peak output. A total annual insolation of $2690 \mathrm{kWh} / \mathrm{m} \mathrm{m}^{2}$, typical of Barstow, California, insolation, is assumed. Because of the way that the annual efficiencies for each component are defined, the total annual energy output from the plant can be calculated by multiplying the total insolation received $\left(2690 \mathrm{kWh} t / \mathrm{m}^{2}\right.$ multiplied by the concentrator field area) by each of the component annual efficiencies. This methodology is not used to predict the annual performance of components but is used only to determine what annual performance is appropriate as a goal. Predictions of component annual performance to determine how attainabie the goals are must use more detailed methodology, preferably an annual of several-year simulation of the component using actual weather conditions and small time steps.

The performance methodology will not identify a poorly designed plant and therefore is not appropriate for plant design studies. The plant configuration must be specified externally to the performance methodology so that a reasonahle design is used in developing component goals. For example, the plant output misthodology described above would not identify any mismatch in the plant design anong the collector field, storage system, and energy conversion system. A joorly designed plant may have a storage system which could never be used bec ause the collector field never produced enough energy; conversely, a plant colld also have a storage system so small that it was often filled and plant energy could not all be used.

\subsection{COMPONENT GOAL DEVELOPMENT}

As described earlier, the two important criteria in developing component goals are that the component goals result in achieving the system energy cost goal and that the component goals are achievable. Determining whether the component goals satisfy the system goal is relatively simple; the energy output of the plant, as explained in Section 4.1, and the LEC of the solar plant are calculated with the methodology described in Appendix A. Determining the 
probability that a given component goal is achievable is more difficult. Achieving the component goals means that a system has been sold industrially, satisfies the performance and cost requirements in the component goals, and meets the 1 ifetime expectations assumed ( 30 years for an electric plant, 20 years for an IPH plant).

Judging the component goals' achievability depends on several assumptions regarding the future of solar thermal technology R\&0 efforts between now and the middle 1990s. The following key assumptions were made during the development of the component goals:

- Government funding for the solar thermal program will continue roughly at its present levels.

- The solar thermal industry will gradually expand sales into the 1990s.

- Research programs directed at increasing the performance/cost ratio of components will continue to be successful.

- Industries will achieve a significant annual sale of solar-specific components. A solar-specific component is one that would not be produced industrially except for use in a solar thermal plant. This assumption is most important for distributed items (such as concentrators), where sales on the order of 10,000-50,000 units/year may be needed to achieve the component goals.

The probability of achieving the component goals cannot be the same for all technologies because the current capabilities of each are different and because all the technologies must achieve the same system goal. Technologies that are less developed have inherently more risk in achieving a given energy cost than technologies with a higher level of development. For this reason, no effort was made to attenpt to normalize the probability of achieving the component goals among the three solar thernal technologies.

The general approach used in developing the component goals was as follows. Technology data sheets (contained in Appendix $C$ ) were provided by the lead R\&D centers (Sandia National Laboratories in Livermore, California, and Albuquerque, New Mexico) for the three solar thermal technologies. These data 
sheets were used as the first step to define the laboratories' best estimate of attainable efficiency and cost for each component of each solar thermal technology, and formed the first "strawman" set of component goals. Initial LEC calculations were made on the basis of the laboratory data sheets and compared to the system goals. This initial set of component goals was then modified in a lengthy review process (which involved industry, national laboratories and DOE) to reflect the following:

- standardization among technologies - The goals were standardized for components which should not vary significantly among the technologies (suich as balance of plant).

- comnents from reviewers - Reviewer comments (where substantiated by either technical reports or industrial data/experience) were used to adjust some of the component goals.

- improved data - As part of the development of component goals, previous solar thermal system and component studies that projected attainable performance and cost were analyzed. In some cases this analysis resulted in the development of better data sources than were useit in the technology data sheets, resulting in revised estimates of achievable component performance and cost.

- nees to meet system goals - As described in Chapter 2, iteration is needed between developing system and component goals because of the conflicting desires in each set of goals (maximizing the payoff for tecnnology development versus maximizing the achievability of the payoff). In some cases the initial set of component goals was judged to be biased too strongly toward being attainable, resulting in not meeting an aggressive system goal. In some of these cases, component goals had to be adjusted toward more optimistic projections of component performance/cost.

The component goals that were developed in this process for the three solar thermal technologies are shown in Table 4.1. 
TABLE 4.1. Long-Term Component Goals

\begin{tabular}{|c|c|c|c|c|}
\hline \multirow[b]{2}{*}{ Component } & \multicolumn{2}{|c|}{ Electric } & \multicolumn{2}{|c|}{ Process Heat } \\
\hline & $\begin{array}{l}\text { Annuat } \\
\text { Efficiency }(\%)\end{array}$ & $\begin{array}{c}\operatorname{cost} \\
(1984 \$) \\
\end{array}$ & $\begin{array}{c}\text { AnnuaT } \\
\text { Efficiency }(\%) \\
\end{array}$ & $\begin{array}{c}\operatorname{cost} \\
(1984 \$)^{(a)}\end{array}$ \\
\hline $\begin{array}{l}\text { Concentrators } \\
\text { Central Receiver } \\
\text { Dish } \\
\text { Trough }\end{array}$ & $\begin{array}{l}64 \\
78 \\
-.\end{array}$ & $\begin{array}{c}100 / m^{2} \\
140 / m^{2} \\
\cdots\end{array}$ & $\begin{array}{l}64 \\
78 \\
65\end{array}$ & $\begin{array}{l}100 / \mathrm{m}^{2} \\
140 / \mathrm{m}^{2} \\
110 / \mathrm{m}^{2}\end{array}$ \\
\hline $\begin{array}{l}\text { Receivers } \\
\text { Central Receiver } \\
\text { Dish } \\
\text { Trough }\end{array}$ & $\begin{array}{l}90 \\
90 \\
--\end{array}$ & $\begin{array}{l}45 / m^{2} \\
70 / m^{2} \\
--\end{array}$ & $\begin{array}{l}90 \\
95 \\
90\end{array}$ & $\begin{array}{l}45 / m^{2} \\
30 / m^{2} \\
30 / m^{2}\end{array}$ \\
\hline $\begin{array}{l}\text { Transport } \\
\text { Central Receiver } \\
\text { Dish } \\
\text { Trough }\end{array}$ & $\begin{array}{r}99 \\
99 \\
--\end{array}$ & $\begin{array}{l}25 / m^{2} \\
7 / m^{2} \\
--\end{array}$ & $\begin{array}{l}99 \\
94 \\
98\end{array}$ & $\begin{array}{l}25 / m^{2} \\
65 / m^{2} \\
30 / m^{2}\end{array}$ \\
\hline $\begin{array}{l}\text { Storage } \\
\text { Central Receiver } \\
\text { Dish } \\
\text { Trough }\end{array}$ & $\begin{array}{l}98 \\
-- \\
--\end{array}$ & $\begin{array}{c}20 / \mathrm{kWh} t \\
-- \\
=-\end{array}$ & $\begin{array}{l}98 \\
98 \\
98\end{array}$ & $\begin{array}{l}20 / \mathrm{kWh}_{\mathrm{t}} \\
20 / \mathrm{kWh}_{\mathrm{t}} \\
20 / \mathrm{kwh} t\end{array}$ \\
\hline $\begin{array}{l}\text { Conversion } \\
\text { Central Receiver } \\
\text { Dish } \\
\text { Trough }\end{array}$ & $\begin{array}{l}39 \\
41 \\
--\end{array}$ & $\begin{array}{c}350 / \mathrm{k} \text { 'Ne } \\
300 / \mathrm{k} \text { we } \\
--\end{array}$ & $\begin{array}{l}\text { NA }(c) \\
\text { NA } \\
\text { NA }\end{array}$ & $\begin{array}{l}\text { NA } \\
\text { NA } \\
\text { NA }\end{array}$ \\
\hline Balance of Plant & NA & $50 / m^{2}$ & NA & $50 / m^{2}$ \\
\hline $\begin{array}{l}\text { System } \\
\text { Central Receiver } \\
\text { Dish } \\
\text { Trough }\end{array}$ & $\begin{array}{l}22 \\
28 \\
--\end{array}$ & $\begin{array}{c}1600 / \mathrm{kWe} \\
1300 / \mathrm{kWe} \\
--\end{array}$ & $\begin{array}{l}56 \\
68 \\
56\end{array}$ & $\begin{array}{l}460 / \mathrm{kWt} \\
470 / \mathrm{kWt} \\
390 / \mathrm{kWt}\end{array}$ \\
\hline $\begin{array}{l}\text { Operations \& Maintenance } \\
\text { Central Receiver } \\
\text { Dish } \\
\text { Trough }\end{array}$ & $\begin{array}{l}\text { NA } \\
\text { NA } \\
--\end{array}$ & $\begin{array}{c}6 / m^{2} \text {-year } \\
10 / m^{2}-\text { year } \\
--\end{array}$ & $\begin{array}{l}\text { NA } \\
\text { NA } \\
\text { NA }\end{array}$ & $\begin{array}{l}5 / m^{2} \text {-year } \\
5 / m^{2} \text {-year } \\
5 / m^{2} \text {-year }\end{array}$ \\
\hline
\end{tabular}

(a) System costs in $\$ / \mathrm{kW}$ are based on theoretical power available from receiver.

(b) Technology goais were not developed for trough electricity.

(c) NA = Not applicable. 


\subsection{COMPONENT GOALS AND SUPPORTING REFERENCES}

Concentrator goals and supporting references are presented in Table 4.2. The goals from the Five Year PIan (DOE 1984b) are shown in the first line of the central receiver, dish, and trough sections. Heliostat cost and performance goals are only slightly more ambitious than estimated in most previous

TABLE 4.2. Concentrator Goals and Supporting References

\begin{tabular}{|c|c|c|c|c|}
\hline \multirow[b]{2}{*}{ Technology/Source } & \multicolumn{2}{|c|}{ Electric } & \multicolumn{2}{|c|}{ Process Heat } \\
\hline & $\begin{array}{l}\text { Annual } \\
\text { Efficiency }(\%)\end{array}$ & $\begin{array}{c}\text { Cost } \\
\left(1984 \$ / \mathrm{m}^{2}\right) \\
\end{array}$ & $\begin{array}{r}\text { Annual } \\
\text { Efficiency }(\%)\end{array}$ & $\begin{array}{c}\cos t \\
\left(1984 \$ / \mathrm{m}^{2}\right)\end{array}$ \\
\hline Central Receiver Goal & 64 & 100 & 64 & 100 \\
\hline Central Receiver (a) & -- & 128 & -- & 128 \\
\hline Central Receiver(b) & -- & 140 & -- & 140 \\
\hline Central Receiver(c) & -- & -- & $46^{(e)}$ & 110 \\
\hline Central Receiver(d) & $47^{(\mathrm{e})}$ & 113 & -- & -- \\
\hline Central Receiver (f) & 60 & 112 & 60 & 112 \\
\hline Central Receiver $(g)$ & $\rightarrow$ & -- & 55 & 85 \\
\hline Dish Goal & 78 & 140 & 78 & 140 \\
\hline $\operatorname{Dish}(a)$ & -- & 190 & -- & 190 \\
\hline $\operatorname{Dish}(c)$ & - & - & $66^{(e)}$ & 144 \\
\hline $\operatorname{Dish}(d)$ & $64^{(e)}$ & 164 & -- & 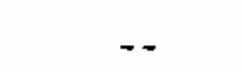 \\
\hline $\operatorname{Dish}(f)$ & -- & -- & 78 & 113 \\
\hline Trough Goal & - & -- & 65 & 110 \\
\hline Trough $(a)$ & $\ldots$ & - & $=-$ & 130 \\
\hline $\operatorname{Trough}(c)$ & - & -- & $38^{(e)}$ & 81 \\
\hline Trough $(f)$ & - & -- & 68 & 96 \\
\hline
\end{tabular}

(a) Radosevich and Caputo 1984.

(b) Drumheller et a 1.1981.

(c) Bird et al. 1981 .

(d) Apley et a 1. 1980 .

(e) Concentrator and receiver efficiency combined.

(f) Battleson 1981 .

(g) Eicker et al. 1981. 
Iong-range studies and are less ambitious than estimates from one study. Previous estimates of dish and trough concentrator cost and performance were also in the range of the goals established in the Five Year Plan.

Receiver goals and supporting references are presented in Table 4.3. The goals from the Five Year Plan (DOE 1984b) are shown in the first line of the central receiver, dish, and trough sections. Previous studies have projected much lower costs for central receivers than does the goal but at only a slightly lower efficiency. Previous dish receiver costs were projected to be lower than the Five Year Plan goals for both electric and IPH applications. Performance was estimated to be higher than the goa? in the one prior estimate of dish receiver efficiency. Less data are available for trough receivers, but available data indicated lower cost estimates than the goals, whereas the performance goal is significantly higher than the efficiency estimate cited.

TABLE 4.3. Receiver Goals and Supporting References

\begin{tabular}{|c|c|c|c|c|}
\hline \multirow[b]{2}{*}{ Technology/Source } & \multicolumn{2}{|c|}{ Electric } & \multicolumn{2}{|c|}{ Process Heat } \\
\hline & $\begin{array}{c}\text { Annual } \\
\text { Efficiency }(\%) \\
\end{array}$ & $\begin{array}{c}\cos t \\
\left(1984 \$ / \mathrm{m}^{2}\right) \\
\end{array}$ & $\begin{array}{c}\text { Annual } \\
\text { Efficiency }(\%)\end{array}$ & $\begin{array}{c}\cos t \\
\left(1984 \$ / \mathrm{m}^{2}\right)\end{array}$ \\
\hline Central Receiver Goal & 90 & 45 & 90 & 45 \\
\hline Central Receiver(a) & -- & -- & - & 22 \\
\hline Central Receiver(b) & -- & 24 & - & - \\
\hline Central Receiver(c) & 88.4 & 17 & 88.4 & 17 \\
\hline Central Receiver (d) & -- & - & 88.6 & 17 \\
\hline Dish Goal & 90 & 70 & 95 & 30 \\
\hline $\operatorname{Dish}^{(a)}$ & -- & -- & -- & 18 \\
\hline Dish(b) & - & 57 & $=-$ & - \\
\hline $\operatorname{Dish}(d)$ & -- & - & 96.3 & 21 \\
\hline Trough Goal & -- & -- & 90 & 30 \\
\hline Trough (a) & -- & - & -- & 13 \\
\hline $\operatorname{Trough}(\mathrm{d})$ & -- & -- & 30.8 & 30 \\
\hline
\end{tabular}

(a) Bird et al. 1981 .

(b) Apley et al. 1980 .

(c) Battleson 1981.

(d) Eicker et a 1. 1981. 
Transport goals and supporting references are presented in Table 4.4. The goals from the Five Year Plan (DOE 1984b) are shown in the first line of the central receiver, dish and trough sections. Previous estimates of central receiver transport costs are much lower than the goals, whereas their corresponding efficiency estimates were in the range of the goals. Prior estimates of dish transport cost and efficiency are slightly less optimistic than the goals. Supporting references for trough transport indicate lower costs than the goals, but also lower annual efficiency.

Storage goals and supporting references are presented in Table 4.5. The goals from the Five Year Plan (DOE 1984b) are shown in the first line of the central receiver, dish, and trough sections. Storage goals are the same for

IABLE 4.4. Transport Goals and Supporting References

\begin{tabular}{|c|c|c|c|c|}
\hline \multirow[b]{2}{*}{ Technology/Source } & \multicolumn{2}{|c|}{ Electric } & \multicolumn{2}{|c|}{ Process Heat } \\
\hline & $\begin{array}{c}\text { Annual } \\
\text { Efficiency }(\%)\end{array}$ & $\begin{array}{c}\cos \mathrm{t} \\
\left(1984 \$ / \mathrm{m}^{2}\right) \\
\end{array}$ & $\begin{array}{c}\text { Ainual } \\
\text { Efficiency }(\%) \\
\end{array}$ & $\begin{array}{c}\cos t \\
\left(1984 \$ / \pi^{2}\right) \\
\end{array}$ \\
\hline Central Receiver Goal & 99 & 25 & 99 & 25 \\
\hline Central Receiver(a) & -- & -- & 99.2 & 4 \\
\hline Central Receiver(b) & 98.4 & 11 & -- & -- \\
\hline Central Receiver $(c)$ & 99.8 & 15 & 99.8 & 15 \\
\hline Central Receiver(d) & -- & -- & 98.9 & 5 \\
\hline Dish Goal & 99 & 7 & 94 & 65 \\
\hline $\operatorname{Dish}^{(a)}$ & -- & -- & 84.7 & 77 \\
\hline $\operatorname{Dish}(b)$ & 95.8 & 9 & -- & - \\
\hline $\operatorname{Dish}^{(d)}$ & -- & -- & 88.1 & 73 \\
\hline Trough Goa & -- & - & 98 & 30 \\
\hline $\operatorname{Trough}(\mathrm{a})$ & -- & - & 94.9 & 16 \\
\hline $\operatorname{Trough}(\mathrm{d})$ & -- & -- & 97.5 & 23 \\
\hline
\end{tabular}

(a) Bird et a 1. 1981.

(b) Apley et a 1. 1980 .

(c) Battleson 1981.

(d) Eicker et a 1. 1981. 
TABLE 4.5. Storage GoaTs and Supporting References

\begin{tabular}{|c|c|c|c|c|}
\hline \multirow[b]{2}{*}{ Technology/Source } & \multicolumn{2}{|c|}{ Electric } & \multicolumn{2}{|c|}{ Process Heat } \\
\hline & $\begin{array}{c}\text { Annual } \\
\text { Efficiency (\%) }\end{array}$ & $\begin{array}{c}\text { cost } \\
\left(1984 \$ / \mathrm{kWh} h_{t}\right)\end{array}$ & $\begin{array}{c}\text { Annual } \\
\text { Efficiency }(q)\end{array}$ & $\begin{array}{c}\text { Cost } \\
\left(1984 \$ / \mathrm{kWh} \mathrm{h}_{\mathrm{t}}\right)\end{array}$ \\
\hline Central Receiver Goal & 98 & 20 & 98 & 20 \\
\hline Central Receiver (a) & -- & -- & 97.6 & 4 \\
\hline Central Receiver(b) & 98.6 & 4 & -- & $\cdots$ \\
\hline Central Receiver $(c)$ & - & 14 & $\because$ & 14 \\
\hline Dish Goal & -- & -- & 98 & 20 \\
\hline $\operatorname{Dish}(a)$ & -- & -- & 96.8 & 6 \\
\hline Trough Goal & -- & -- & 98 & 20 \\
\hline Trough $(a)$ & -- & -- & 95.3 & 6 \\
\hline
\end{tabular}

\footnotetext{
(a) Bird et al. 1981 .

(b) Apley et al. 1980 .

(c) Battleson 1981 .
} 
each technology: $\$ 20 / \mathrm{kWt}$ and $98 \%$ annual efficiency. Previous studies estimated storage cost to be significantly less than the goals within each technology, while efficiency estimates were in the range of the goals.

Energy conversion goals and supporting references are presented in Tabie 4.6. The goals from the Five Year Plan (DOE 1984b) are shown in the first line of the central receiver and dish sections. Cost and performance goals for central receiver energy conversion are supported by estimates from two other studies. One study estimated cost and efficiency to be nearly identica! with the goals, whereas the other study projected much higher efficiency, but at a higher cost.

Balance-of-plant goals and supporting references are presented in Table 4.7. The goals from the Five Year Plan (DOE 1984b) are shown in the first line of the central receiver, dish, and trough sections. Balance-ofplant goals established in the Five Year Plan are identical $\left(\$ 50 / \mathrm{m}^{2}\right)$ across technologies. Previous estimates of balance-of-plant items indicate that the goal should be achievable.

System goals and supporting references are presented in Table 4.8. The goals from the Five Year Plan (DOE 1984b) are shown in the first line of the central receiver, dish, and trough sections. The system cost goals $(\$ / \mathrm{kW})$ are based on the theoretical peak power available from the receiver. Previously

TABLE 4.6. Conversion Goals and Supporting References

\begin{tabular}{|c|c|c|}
\hline \multirow[b]{2}{*}{ Technology/Source } & \multicolumn{2}{|c|}{ Electric } \\
\hline & $\begin{array}{c}\text { Annua } \\
\text { Efficiency }(\%) \\
\end{array}$ & $\begin{array}{c}\text { Cost } \\
(1984 \$ / \mathrm{kWe})\end{array}$ \\
\hline Central Receiver Goal & 39 & 350 \\
\hline Central Receiver(a) & 38.3 & 350 \\
\hline Central Receiver (b) & 43.0 & 440 \\
\hline Dish Goal & 41 & 300 \\
\hline $\operatorname{Dish}(a)$ & 34.3 & 290 \\
\hline
\end{tabular}

(a) Apley et al. 1980.

(b) Battleson 1981 . 
TABLE 4.7. Balance of Plant Goals and Supporting References

\begin{tabular}{|c|c|c|c|c|c|}
\hline \multirow[b]{2}{*}{ Technology/Source } & \multicolumn{3}{|c|}{ Electric } & \multicolumn{2}{|c|}{ Process leat } \\
\hline & $\begin{array}{r}\text { Annua! } \\
\text { Efficiency } \\
\end{array}$ & $(\%)$ & $\begin{array}{c}\operatorname{cost} \\
\left(1984 \$ / \mathrm{m}^{2}\right)\end{array}$ & $\begin{array}{r}\text { Annuat } \\
\text { Efficiency }(\%)\end{array}$ & $\begin{array}{c}\text { Cost } \\
\left(1984 \$ / \mathrm{m}^{2}\right)\end{array}$ \\
\hline Central Receiver Goal & $\rightarrow$ & & 50 & -- & 50 \\
\hline Central Receiver(a) & -- & & -- & -- & 46 \\
\hline Central Receiver(b) & - & & 22 & -- & -- \\
\hline Central Receiver $(c)$ & -- & & 30 & -- & 36 \\
\hline Central Receiver $(d)$ & -- & & -- & - & 31 \\
\hline Dish Goal & -- & & 50 & -- & 50 \\
\hline $\operatorname{Dish}(\mathrm{a})$ & -- & & -- & -- & 52 \\
\hline $\operatorname{Dish}(b)$ & - & & 32 & -- & - \\
\hline $\operatorname{Dish}(d)$ & -- & - & -- & -- & 31 \\
\hline Trough Goal & -- & & - & -- & 50 \\
\hline $\operatorname{Trough}(a)$ & -- & & -- & -- & 31 \\
\hline Trough $(d)$ & $-\infty$ & & $=-$ & -- & 30 \\
\hline
\end{tabular}

(a) Bird et a 1. 1981.

(b) Apley et al. 1980.

(c) Battleson 1981.

(d) Eicker et al. 1981.

estimated system costs for central receivers are generally less than the cost goals, whereas estimated performance is not as good as the standards set by the goals. The same pattern holds for dish and trough systems.

0\&M goals and supporting references are presented in Table 4.9. The goals from the Five Year Plan (DOE 1984b) are shown in the first line of the central receiver, dish, and trough sections. O\&M cost goals are the same for each process heat system and higher by different amounts for the central receiver and dish electric systems. Previous 0\&M estimates tend to be in the range of the established goals. 
TABLE 4.8. System Goals and Supporting References

\begin{tabular}{|c|c|c|c|c|}
\hline \multirow[b]{2}{*}{ Technology/Source } & \multicolumn{2}{|c|}{ Electric } & \multicolumn{2}{|c|}{ Process Heat } \\
\hline & $\begin{array}{c}\text { Annua? } \\
\text { Efficiency }(\%)\end{array}$ & $\begin{array}{c}\text { Cost } \\
(1984 \$ / \mathrm{kWe}) \\
\end{array}$ & $\begin{array}{c}\text { Annual } \\
\text { Efficiency }(\%) \\
\end{array}$ & $\begin{array}{c}\operatorname{cost} \\
(1984 \$ / \mathrm{kWt})\end{array}$ \\
\hline Central Receiver Goal & 22 & 1600 & 56 & 460 \\
\hline Central Receiver $(a)$ & -- & -- & 46.5 & 340 \\
\hline Central Receiver(b) & 17.4 & 1850 & -- & - \\
\hline Central Receiver(c) & 20.7 & 1370 & 52.8 & 390 \\
\hline Central Receiver(d) & $\rightarrow$ & - & 54.2 & 260 \\
\hline Dish Coa! & 28 & 1300 & 68 & 470 \\
\hline $0 i \operatorname{sh}^{(a)}$ & -- & -- & 58 & 430 \\
\hline $\operatorname{Dish}(b)$ & 21.1 & 1520 & $\ldots$ & - \\
\hline $\operatorname{Dish}(d)$ & -- & - & 60 & 320 \\
\hline Trough Goa? & -- & -- & 56 & 390 \\
\hline Trough'a) & -- & $-\rightarrow$ & 36.8 & 190 \\
\hline Trough:d) & -- & - & 48.8 & 260 \\
\hline
\end{tabular}
(a) Bird et a 1. 1981 .
(b) Apley et al. 1980.
(c) Battleson 1981 .
(d) Eicker et al. 1981. 
TABLE 4.9. O\&M Goals and Supporting References

\begin{tabular}{|c|c|c|c|c|}
\hline \multirow[b]{2}{*}{ Technology/source } & \multicolumn{2}{|c|}{ Electric } & \multicolumn{2}{|c|}{ Process Heat } \\
\hline & $\begin{array}{c}\text { Annua } \\
\text { Efficiency }(\%)\end{array}$ & $\begin{array}{l}\operatorname{cost}(1984 \\
\left.\$ / m^{2} / y r\right) \\
\end{array}$ & $\begin{array}{l}\text { Annual } \\
\text { Efficiency }(\%)\end{array}$ & $\begin{array}{l}\text { Cost }(1984 \\
\left.\$ / m^{2} / y r\right) \\
\end{array}$ \\
\hline Central Receiver Goal & $=$ & 6 & -- & 5 \\
\hline Central Receiver(a) & -- & -- & $=$ & 1.7 \\
\hline Central Receiver ${ }^{(b)}$ & - & 2 & - & - \\
\hline Central Receiver(c) & -- & 6.6 & $\rightarrow-$ & 6.6 \\
\hline Central Receiver(d) & -- & -- & $=-$ & 3.8 \\
\hline Dish Goal & -- & 10 & -- & 5 \\
\hline $\operatorname{dish}(a)$ & -- & -. & - & 8.2 \\
\hline $\operatorname{Dish}^{(b)}$ & -- & 4 & -- & - \\
\hline $\mathrm{Dish}^{(d)}$ & -- & $\cdots$ & - & 6.7 \\
\hline Trough Goal & -- & -- & - & 5 \\
\hline $\operatorname{Trough}^{(a)}$ & -- & -- & $\cdots$ & 6.1 \\
\hline Trough (d) & $\ldots$ & -- & -- & 5 \\
\hline
\end{tabular}
(a) Bird et a 1. 1981.
(b) Apley et al. 1980.
(c) Battleson 1981 .
(d) Eicker et al. 1981. 


\subsection{ALTERNATIVE GOALS AND SYSTEM TRADEOFFS}

The component goals listed in the Five Year Plan (DOE 1984b) represent just one way of meeting the energy cost targets. Those goals could also be achieved by other paths (alternative components) because many tradeoffs are possible among component efficiencies and costs. Alternative components are fundamentally different than the components assumed in the long-term goals. For example, concentrators for the central receiver long-term goal are assumed to be glass/metal heliostats with an annual efficiency of $64 \%$ and a cost of

$\$ 100 / \mathrm{m}^{2}$. An alternative, stressed membrane heliostats, may not be able to meet the $64 \%$ afficiency goal but could cost considerably less than glass/metal heliostats. Thus, a method for developing goals for alternative components is clearly needed. Section 5.1 describes one way to develop alternative (but equivalent) component goals for the various solar thermal technologies and applications. At the system level, the cost and performance requirements that will mee: the system target energy costs also are very flexible; higher efficienisy is not necessarily better if it means much higher costs. Systemlevel tradeoff equations for capital investment, systen efficiency, and annual $0 \&$ a re presented in Section 5.2 .

\subsection{ALTERNATIVE COMPONENT GOALS}

Many degrees of freedom exist in developing component goals because of tradeoffs between component efficiency and cost. As a result, no unique set of component goals alone satisfies the system goal; several solutions are feasible. In this section a method for calculating alternative goals for components will be shown.

If all the component goals for a particular technology and application are met, the systen target energy cost will be attained. For each component, three factors determine the component's contribution to the system levelized energy cost (LEC): capital investment, average annual efficiency, and annual O\&M costs. The long-term capital investment and annual efficiency targets are explicitly stated in the Five Year Plan (DOE 1984b); however, the annual 0\&l1 costs are not given for each component but are lumped together for the entire 
system. As 0\&M costs become better characterized, they may be targeted on a component basis in future versions of solar thermal technology goals.

Expression 5.1 below is used to determine whether an alternative component can meet the long-term goals listed in Table 4.1. A figure of merit (FOM), a performance rating that governs the choice of a device for a particular application, is defined by

$$
F O M=\left(\frac{n_{5 Y P}}{n_{\text {comp }}}\right)\left(\frac{C I_{\text {comp }}}{C_{\text {IF }}}+S Y S_{5 Y p}+\frac{\Delta 0 \& M}{\overline{A C}_{\text {comp }}}\right)
$$

where:

$$
\begin{aligned}
& \eta_{5 Y P}=\text { The component annual efficiency } 1 \text { isted under long-term } \\
& \text { goals in Table } 4.1 \text {. } \\
& n_{\text {comp }}=\text { The estimated annual efficiency of the alternative compo- } \\
& \text { nent in the middle-to-late 1990's time frame. } \\
& C I_{\text {comp }}=\text { The estimated installed capital cost of the alternative } \\
& \text { component in the middle-to-late 1990's time frame. } \\
& \text { CIF }{ }_{\text {app }}=\text { The capital investment adjustment factor. CI comp divided } \\
& \text { by this factor is the percentage of Iong-term target } \\
& \text { annual costs that are contributed by each component. } \\
& \text { Consistent with the approach used in developing the goals, } \\
& \text { indirects and contingency (I\&C) are included in this fac- } \\
& \text { tor and assumed to be } 20 \% \text { of the installed capital } \\
& \text { costs. CIF app varies with the technology and application. } \\
& \text { SYS }_{5 Y P}=\text { The percentage of long-term target annual costs that are } \\
& \text { contributed by the O\&M costs and the other components in } \\
& \text { the system. } \\
& \triangle 0 \& M_{\text {Comp }}=\text { The difference between the first year } 0 \& M \text { costs for the } \\
& \text { component listed in the Table } 4.1 \text { long-term goals and the } \\
& \text { alternative component. The value can be negative or posi- } \\
& \text { tive. (Note that the 0\&M costs are not explicitly stated } \\
& \text { in the Five Year Plan (DOE 1984b) on a component basis.) }
\end{aligned}
$$


$A C_{a p p}=$ The annualized long-term target system costs. The difference in the first year OSM costs divided by $A C_{a p p}$ is the percentage of long-term target annual costs that are contributed by this change in $08 M$ costs.

When the FOM equals one, the component goal is (equivalentiy) met. If the FOM is greater than one, then the goal has not been met; conversely, if the FOM is less than one, then the component goal has been exceeded. The FoM may be set equal to one and solved for the breakeven value of the unknown variable ( $n_{\text {comp }}$, $I_{\text {comp }}$, or $\triangle 0 \& M_{\text {comp }}$ ) if the other two variables are known.

Changes in annual efficiency with no change in peak efficiency are assumed not to require changes in plant design. Because the goal assumes that system efficiency is the product of the component efficiencies, the output will change by the percentage change in the annual efficiency. When a change in one component (e.g., a change in peak efficiency) results in the system having to be redesiyned, or when the cost (CI or O\&M) or efficiency of more than one component is different than the long-term-goal, then the system-level tradeoff equations for the capital investment, system efficiency, and annual oal in Section 5.2 should be used.

If a component does not meet its goal, it could still be used as part of a system that meets the long-term energy cost goal. For example, the long-termgoal for the dish electric system assumes a high temperature receiver (up to $1370^{\circ} \mathrm{C}$ ) and a high-efficiency Stirling-or Brayton-cycle engine. If an organic Rankine-cycle (ORC) engine is assumed, then the engine component goal would probably not be met because of the much lower engine efficiency. However, the optimal ORC dish system might be able to use a lower temperature, higher efficiency receiver and a lower efficiency, lower-cost concentrator than were assumed for the Stirling- or Brayton-cycle engine dish configurations. Because several components would be different than assumed in the long-term-goals, the systemrlevel tradeoff equations for the capital investment, systern efficiency, and annual 0\&M in Section 5.2 should be used to determine if the energy cost target can be met with this system configuration.

Tables 5.1 through 5.5 show the values to be used in Expression 5.1 to calculate alternative component goals for each technology and application. 
TABLE 5.1. Central Receiver Electric (CRE)

\begin{tabular}{|c|c|c|c|c|c|}
\hline Component & $n_{5 Y p}$ & $\begin{array}{l}{ }^{C I F} \mathrm{CBE} \\
\left(\times 10^{5}\right) \\
\end{array}$ & $S Y S_{5 Y P}$ & $\begin{array}{l}A \mathcal{C}_{\text {CRE }} \\
\left(\times 10^{4}\right)\end{array}$ & $\begin{array}{l}\text { Current } \\
\text { Capability (a) } \\
\text { FOM }\end{array}$ \\
\hline Concentrator & 0.64 & 2407 & $\overline{0.7404}$ & 1834 & 1.499 \\
\hline Receiver & 0.90 & 2407 & 0.8832 & 1834 & 1.055 \\
\hline Conversion & 0.39 & 2407 & $0.840 !$ & 1834 & 1.390 \\
\hline Transport & 0.99 & 2407 & 0.9351 & 1834 & 1.136 \\
\hline Storage & 0.98 & 2407 & 0.9356 & 1834 & 1.241 \\
\hline$B O P$ & NA & 2407 & 0.8702 & 1834 & 1.054 \\
\hline
\end{tabular}

(a) Concentrator capital investment is the product of the current concentratgr cost in $\$ / \mathrm{m}^{2}$ and the long-term concentrator area $\left(625,000 \mathrm{~m}^{2}\right)$. Receiver capital investment is scaled with rated output using a 0.8 power scale factor. Conversion capital investment is scaled with rated output using a 0.85 power scale factor. Storage capital investment is scaled linearly with size $(\mathrm{kWh})$. Transport and BOP capital investment are scaled linearly with rated plant output. NA $=$ Not applicable.

TABLE 5.2. Central Receiver Industrial Process Heat (CRIPH)

\begin{tabular}{|c|c|c|c|c|c|}
\hline Component & $n_{5 Y P}$ & $\begin{array}{c}C I F_{C R I P H} \\
\left(\times 10^{5}\right) \\
\end{array}$ & $S Y S_{5 Y P}$ & $\begin{array}{l}{ }^{A C} C_{C R} P^{P H} \\
\left(\times 10^{4}\right)\end{array}$ & $\begin{array}{l}\text { Current } \\
\text { Capability (a) } \\
\text { FOM }\end{array}$ \\
\hline Concentrator & 0.64 & 1584 & 0.6053 & 2888 & 1.673 \\
\hline Receiver & 0.90 & 1584 & 0.8224 & 2888 & 1.084 \\
\hline Transport & 0.99 & 1584 & 0.9013 & 2888 & 1.207 \\
\hline Storage & 0.98 & 1584 & 0.9765 & 2888 & 1.088 \\
\hline BOP & NA & 1584 & 0.8027 & 2888 & 1.307 \\
\hline
\end{tabular}

(a) The capital investment scaling method is the same as in Table 5.1. NA $=$ Not applicable. 
TABLE 5.3. Dish Electric (DE)

\begin{tabular}{|c|c|c|c|c|c|}
\hline Component & $n_{5 Y P}$ & $\begin{array}{l}\mathrm{CIF}_{D E_{5}} \\
\left(\times 10^{5}\right)\end{array}$ & $S Y S_{5 Y P}$ & $\begin{array}{c}A C_{D E} \\
\left(\times 10^{4}\right)\end{array}$ & $\begin{array}{c}\text { Current } \\
\text { Capability }(\mathrm{a}) \\
\text { FOM }\end{array}$ \\
\hline Concentrator & 0.78 & 3115 & 0.7191 & 2373 & 2.545 \\
\hline Receiver & 0.90 & 3115 & 0.8596 & 2373 & 1.562 \\
\hline Conversion & 0.41 & 3115 & 0.7991 & 2373 & 3.405 \\
\hline Transport & 0.99 & 3115 & 0.9860 & 2373 & 1.006 \\
\hline $\mathrm{BOP}$ & NA & 3115 & 0.8997 & 2373 & 1.132 \\
\hline
\end{tabular}
(a) All component capital investments are the product of the current component cost in $\$ / \mathbb{Q}^{2}$ and the long-term target concentrator area $\left(625,000 \mathrm{~m}^{2}\right)$, except conversion, which is the product of the current component cost in $\$ / k W_{\text {peak }}$ and the long-term target peak output.
$N A:=$ Not applicable.

\section{TABLE 5.4. Dish Industrial Process Heat (DIPH)}

\begin{tabular}{|c|c|c|c|c|c|}
\hline Component & $n_{5 Y P}$ & $\begin{array}{l}C_{D I F H} \\
\left(x 10^{5}\right)\end{array}$ & $S_{Y Y S_{5 Y P}}$ & $\begin{array}{c}{ }^{A C_{D I P H}} \\
\left(x 10^{4}\right)\end{array}$ & $\begin{array}{l}\text { Current } \\
\text { Capability (a) } \\
\text { FOM }\end{array}$ \\
\hline Concentrator & 0.78 & 1999 & 0.5622 & 3646 & 3.264 \\
\hline Receiver & 0.95 & 1999 & 0.9062 & 3646 & 1.617 \\
\hline Transport & 0.94 & 1999 & 0.7968 & 3646 & 1.169 \\
\hline Storage & 0.98 & 1999 & 0.9769 & 3646 & NA \\
\hline BOP & NA & 1999 & 0.8437 & 3646 & 1.219 \\
\hline
\end{tabular}

(a) The capital investment scaling method is the same as in Table 5.3.

$N A=$ Not applicable.

FOMs for the current capabilities are also listed in the tables for each component in a technology and application. In calculating the current capabilities FOMs, all the components in the system were assumed to be the same as the longterm targets, with the exception of the component in question. These foMs can be used to show how an alternative component currently compares with the 
TABLE 5.5. Trough Industrial Process Heat (TIPH)

\begin{tabular}{|c|c|c|c|c|c|}
\hline Component & $n_{5 Y P}$ & $\begin{array}{l}\mathrm{CIF}_{\mathrm{TIPH}} \\
\left(x 10^{5}\right)\end{array}$ & $S Y S_{5 Y P}$ & $\begin{array}{l}\mathrm{AC}_{\text {TIPH }} \\
\left(x 10^{4}\right)\end{array}$ & $\begin{array}{c}\text { Current } \\
\text { Capability }(a) \\
\text { FOM }\end{array}$ \\
\hline Concentrator & 0.65 & 1590 & 0.5677 & 2901 & 2.000 \\
\hline Receiver & 0.90 & 1590 & 0.8821 & 2901 & 1.247 \\
\hline Transport & 0.98 & 1590 & 0.8821 & 2901 & 1.039 \\
\hline Storage & 0.98 & 1590 & 0.9723 & 2901 & NA \\
\hline BOP & NA & 1590 & 0.8035 & 2901 & 1.275 \\
\hline
\end{tabular}
(a) All component capital investments are the product of the current component cost in $\$ / \mathrm{m}^{2}$ and the long-term target concentrator area $\left(625,000 \mathrm{~m}^{2}\right)$.
$N A=$ Not applicable.

components used in the near-term system. If an alternative component were being developed, and its long-term target costs and efficiency resulted in an FOM greater than the current capabilities FOM, then continued development efforts on this component would not be warranted.

Values calculated from Expression 5.1 for different components cannot be directly compared with values for other technologies or applications. The results of Expression 5.1 can only be compared within the same technology and application for a particular component. As an example of the proper use of Expression 5.1, an alternative component goal for stressed membrane heliostats (SMH) is calculated below. The critical assumptions are as follows:

- The peak efficiency is the same as the glass/metal heliostat goal. Thus, the peak flux on the receiver is unchanged and the plant design does not need to be changed.

- The average annual efficiency of the stressed membrane heliostat is $63 \%$ versus the long-term annual efficiency goal for glass/metal heliostats of $64 \%$.

- The membrane lifetime is 10 years. Membrane replacement occurs at the end of years 10 and 20 . 
- Generaliy, replacement equipment must be depreciated, but for tax purposes the membrane replacement costs in this example are assumed to be expensed.

- The only change in annual O\&M costs is for membrane replacement.

- Membrane replacement costs are $\$ 10 / \mathrm{m}^{2}$ for material and $\$ 2.40 / \mathrm{m}^{2}$ for labor. This is equivalent to an increase in $0 \& M$ of $\$ 512,400$ per annum.

- The long-term installed cost goal for glass/metal heliostats is $\$ 100) / \mathrm{m}^{2}$.

- Concentrator area is $625,000 \mathrm{~m}^{2}$.

Inserting the information above into Expression 5.1 and setting it equal to 1 yields:

$$
1=\left(\frac{0.64}{0.63}\right)\left(\frac{C I_{S M H}}{2407 \times 10^{5}}+0.7404+\frac{512400}{1834 \times 10^{4}}\right)
$$

Solving the above equation for $\mathrm{CI}_{S M H}$, the installed cost for the stressed membrane heliostat field, results in $\mathrm{CI}_{S M H}$ equal to $\$ 52,000,000$. Since the concentrator area is $625,000 \mathrm{~m}^{2}$, the stressed membrane heliostat cost required to meet the component goal is $\$ 83.20 / \mathrm{m}^{2}$. Thus, if all the assumptions are valid, one would be indifferent between purchasing the higher-performance metal/glass heliostats at $\$ 100 / \mathrm{m}^{2}$ and lower-performance stressed membrane heliostats at $\$ 83.20 / \mathrm{m}^{2}$. Therefore, either heliostat design would meet the concentrator goal, and if all the other component goals were met, the systern target energy cost could be achieved with either concentrator system.

\subsection{CAPITAL INVESTMENT, SYSTEM EFFICIENCY, ANO ANNUAL O\&M TRADEOFFS}

The equations for the capital investment, system efficiency, and annual 0\&M tradeoffs presented in this section should be used to determine if the energy cost target can be met with a system configuration different than assumed in developing the goals under the following conditions: 
- when a change in one component (e.g., a change in peak efficiency) results in the system having a design different than the design assumed in the long-term targets

- when the cost (CI or 0\&M) or efficiency of more than one component is different than the long-term-goal.

If only one component is different than those listed in the long-term targets, and the plant design is assumed to be the same (no changes in peak efficiency), then the expression in Section 5.1 should be used.

The equations below are three forms of the same equation. If two of the three variables are known, the equations will yield the values that are necessary to exactly match the LEC of the systems goal. If the system cost, annual energy output, and annual 0\&M costs are known, then the LEC for that system can be calculated using the equations in Appendix $A$.

$$
\begin{gathered}
\Delta C I=\frac{A C\left[\left(\eta_{A S} / n_{S G}\right)-1\right]-\Delta 0 \& M}{C I L} \\
\Delta 0 \& M=A C\left[\left(n_{A S} / \eta_{S G}\right)-1\right]-(C I L * \Delta C I) \\
\eta_{A S}=\left(\frac{(C I L * \Delta C I)+\Delta 0 \& M}{A C}+1\right) n_{S G}
\end{gathered}
$$

where:

$\Delta C I=$ The difference between the estimated alternative system capital investment in the middle-to-late 1990's time frame, and the long-term estimated system capital investment for the particular technology and application in the five Year Plan (DOE 1984b). The system capital investment is the installed cost plus indirects and contingencies of $20 \%$. The value of $\Delta C I$ can be negative or positive.

$A C=$ The annualized long-term target system costs. The value for each technology and application is listed in Table 5.6. These are the same values that were used in Section 5.1 . 


$$
\begin{aligned}
\text { maS }= & \text { The estimated annul efficiency for the alternative system in } \\
& \text { the middle-to-late } 1990 \text { 's time frame. The system efficiency } \\
& \text { is assumed here, as in the Five Year Plan (DOE 1984b), to be } \\
& \text { the product of the component efficiencies. The system output } \\
& \text { will change by the percentage change in annual efficiency. } \\
n_{S 1}= & \text { The annual system efficiency goal for the long-term target } \\
& \text { systems in the middle-to-late } 1990 \text { 's time frame. } \\
\Delta 0 \& 11= & \text { The difference between the annual 0\&M costs for the estimated } \\
& \text { alternative system in the middle-to-late } 1990 \text { 's time frame and } \\
& \text { the long-term system 0\&M costs listed in the Five Year Plan } \\
& \text { (DOE l984b) for each technology and application. The value of } \\
& 0 \& M \text { can be negative or. positive. } \\
\mathrm{CIL}= & \text { The capital levelizing factor. The value for each application } \\
& \text { is listed in Table } 5.6 \text {. }
\end{aligned}
$$

\begin{tabular}{|c|c|c|c|}
\hline Technology and Application & $\begin{array}{c}A C^{4} \\
\left(\times 10^{4}\right) \\
\end{array}$ & CIL & ISG \\
\hline Central Receiver Electric & 1834 & 0.06347 & 0.2179 \\
\hline Central Receiver IPH & 2888 & 0.1520 & 0.5588 \\
\hline Dish Electric & 2373 & 0.06347 & 0.2849 \\
\hline Dish IPH & 3646 & 0.1520 & 0.6826 \\
\hline Trough IPH & 2901 & 0.1520 & 0.5618 \\
\hline
\end{tabular}

Table 5.6 lists the parameters to be used in Equations $5.3,5.4$, and 5.5 for each technology and application.

To show how to use these equations, the value of a $1 \%$ improvement in system annual efficiency for the central receiver electric system will be calculated. The value of an efficiency improvement can be calculated as the additional capital investment or annual 0\&M costs that would result in the LEC being unchanged. A change in annual system efficiency could, for example, result from increased concentrator cieaning (an increase in annual 0\&M costs)

\section{TABLE 5.6. Tradeoff Equation Parameters}


or improved heliostat availability due to the use of more reliable and more expensive drive units (an increase in capital investment).

Equation 5.4 is used to calculate the value of a $1 \%$ improvement in system annual efficiency in terms of increased annual 0\&M costs. Inserting the parameters from Table 5.6 yields:

$$
\Delta 08 M=1834 \times 10^{4}[(1.01)-1]=\$ 183,400 \text { per annum. }
$$

To calculate the value of a $1 \%$ improvement in system annual efficiency in terms of increased capital investment, Equation 5.3 is used. Inserting the parameters from Table 5.6 yields:

$$
\Delta C I=\frac{1834 \times 10^{4}[(1.01)-1]}{.06347}=\$ 2,890,000^{\star} .
$$

*Includes approximately $\$ 2,400,000$ of capital costs plus $20 \%$ for indirects and contingencies.

Thus, for a $1 \%$ improvement in long-term target for annual system efficiency of the central receiver electric system, one would be willing to pay approximately $\$ 2,400,000$ more in capital costs (plus I\&C of $20 \%$ ), or $\$ 183,400$ more in annual 0\&M costs. An unlimited number of combinations of 0\&M and capital cost changes will result in no change in the system LEC for a given change in system efficiency. If the capital investment and annual 0\&M cost changes are known, Equation 5.5 could be used to calculate the required system efficiency that would result in the same LEC as the long-term-goal. 


\section{APPENDIX A}

LEVELIZED ENERGY COST CALCULATIONS 
APPENOIX A

LEVELIZED ENERGY COST CALCULATIONS

This appendix provides general information on levelized energy cost (LEC) calculations and on methods used to calculate the LEC in developing solar thermal systern goals and component goals. In the first section, some definitions related to LEC are presented, and the standard assumptions used for calculating the techrology goals are described. The second section provides general methodology that can be used even if some of the standard assumptions used in developirg the goals were changed. The third section presents a streamlined method which can be used for LEC calculations of solar thermal plants when the standard assumptions are followed in developing the goals.

\section{A.1 DEF:NITIONS AND ASSUMPTIONS}

Several sources of information may be helpful in understanding the basis for LEC calculations. The report Solar Thermal Financing Guidebook (Williams et a1. 1983) provides some general information relating to the concepts of life-cycle cost and economic evaluation, which are the backbone of LEC calculations. A good discussion of the general approach to LEC calculations, along with generalized equations, is contained in The Cost of Energy From Ut ility-Owned Solar Electric Systems (Doane et al. 1976). Another useful references is the Technical Assessment Guide [(EPRI) 1982], which describes both economic evaluation concepts and LEC calculations. The form of the LEC equations differs somewhat between the EPRI and Doane references, as does the level of detail in the calculation (EPRI tends to be more detailed analytically), although the approaches yield equivalent results as long as the relevant cost streams considered are identical. The analytical approach and equations in this section follow the approach in Doane somewhat more closely than EPRI.

Some of the terms and basic financial concepts used in the LEC methodology (and other financial evaluation approaches) are described below: 
- Time Value of Money - People prefer to consume goods today (spend money); therefore, they must be compensated in some way (interest) to persuade them to postpone consumption to a future date (saving). Hence, money has time value.

- Discount Rate - The factor used to account for the time value of money in economic calculations is the discount rate. It is the minimum rate of return that an investor is willing to accept from an investment. The appropriate discount rate for many calculations is the "cost of capital," the cost to a firm for obtaining funds through debt (loans and bonds) and equity (stock) sales. Firms generally adjust their discount rate to account for risk when evaluating specific projects with a level of risk that is different from the rest of the company's business; the greater the risk, the higher the discount rate.

- Present Value - Present value is a method to adjust future cash flows to equivalent cash flows occurring in the present, accounting for the time value of money. If the discount rate is $10 \%$, the present value of $\$ 100$ received today and $\$ 110$ received in one year is equivalent (both present values $=\$ 100)$.

- Inflation and Escalation - Inflation is a general change in the purchasing power of money due to a rise in the price of all goods (on average) over time. Escalation refers to changes in the price of a specific item. For example, the general level of prices could be stable (0\% inflation) while the prices for petroleum products could increase by $2 \%$ ( $2 \%$ escalation).

- Real and Nominal Dollars - These may also be referred to as constant and current dollars, respectively. Real dollars are dollars of constant purchasing power; they do not include the effects of general inflation. Nominal dollars are actual face-value amounts; these include the effects of inflation. Economic evaluations can be done in either real or nominal dollars as long as all inputs (discount rate, cash flows, etc.) are appropriately corrected for inflation. 
- Risk - The two major areas of risk are fuel price risk and technical risk. Fuel price risk depends on the variability of fuel prices. Solar plants are insulated from fuel price changes. After a solar plant is completed, the delivered cost of energy from the plant is relatively fixed in real terms. Changes in fuel prices will cause large changes in the delivered cost of energy from a fossil-fired plant because most of the delivered cost is due to the cost of fuel. Technical risk is a measure of the probability that a plant will perform as expected. The technical risk is currently high for solar thermal and low for established technologies.

- Annual Operation and Maintenance (OBM) Costs - These are costs that occur during the operating lifetime of the power plant; fuel costs are included for fossil-fired plants.

- Capital Costs - These are costs that are generally associated with construction of the power plant. They generally occur before plant operation and include startup costs, although some types of capital costs (for plant replacement equipment) may also occur after the beginning of plant operations. For solar plants, costs occurring before the plant is operating are generally all capital costs. Costs occurring during plant operation are 0\&M costs unless they are for itens which must be depreciated rather than expensed.

- Payback Period - The payback period is the time it takes to pay back an investment, in nominal dollars, out of the revenues or savings the investment generates. To determine whether a project would be accepted, or whether an energy cost target is met, the payback period would have to be less than a predetermined time limit. This method ignores the time value of money; thus, it is only a valid economic evaluation methodology under a highly restrictive assumptions. The payback period method is widely employed by industry because of its simplicity, but it is rarely used by itself as a decision rule.

A miore complete discussion of the concepts and evaluation methodologies described in this section is presented in the Solar Thermal Financing Guidebook (Williams et a1. 1983). 
Because of differences in the tax laws between solar and fossil plants, and utility versus industrial ownership, different assumptions are required for the LEC analysis. Industrial ownership is assumed to require a higher rate of return than utility ownership; this is evidenced by a higher discount rate and a shorter solar system lifetime assumed for industrial ownership. Depreciation schedules also differ with application and ownership. Differences in assumptions between systems and component goals reflect the fact that system goals are based on the competition to solar thermal, while component goals are based on solar thermal systems. This creates the need for some essential differences in assumptions (such as for efficiencies for conventional IPH sources) and differences in depreciation schedules because of the $t a x$ laws. The standard assumptions for the LEC calculations are listed and described in Tables A.I through $A .5$.

TABLE A.1. Standard Assumptions: Genera? Assumptions Applicable to Al l LEC Calculations

\begin{tabular}{|c|c|c|}
\hline Variable & Value & Description \\
\hline General inflation rate & $0 \%$ & $\begin{array}{l}\text { Al) LEC estimates calculated in real } \\
\text { dollars assuming } 0 \text { inflation. }\end{array}$ \\
\hline Capital cost escalation & $0 \%$ & $\begin{array}{l}\text { Capital costs assumed to not escalate in } \\
\text { absence of inflation. }\end{array}$ \\
\hline O\&M cost escalation & $0 \%$ & $\begin{array}{l}\text { 0\&M costs assumed to not escalate in } \\
\text { absence of inflation. }\end{array}$ \\
\hline Construction cash flows & uniform & $\begin{array}{l}\text { Cash flows occur uniformly throughout } \\
\text { construction; i.e., for } 3 \text {-year construc- } \\
\text { tion, one-third of cost incurred in each } \\
\text { year. }\end{array}$ \\
\hline Base year for discounting & startup & $\begin{array}{l}\text { All discounted cash flow calculations } \\
\text { discounted to beginning of first-year } \\
\text { plant operations. All cash flows are } \\
\text { assumed to occur at the end of each year. }\end{array}$ \\
\hline Base year for prices & 1984 & All costs are given in 1984 dollars. \\
\hline
\end{tabular}


TABLE A.2. Standard Assumptions for System Goals for Electricity

\begin{tabular}{|c|c|c|}
\hline Variable & Value & Description \\
\hline Plant construction time & $3 \mathrm{yr}$ & $\begin{array}{l}\text { The amount of time required to construct } \\
\text { a fossil-fueled (coal) power plant. }\end{array}$ \\
\hline Economic life & $30 \mathrm{yr}$ & $\begin{array}{l}\text { A standard assumption for utility plant } \\
\text { lifetime. }\end{array}$ \\
\hline Depreciation time & $15 \mathrm{yr}$ & Current tax law. \\
\hline Depreciation schedule & $\operatorname{ACRS}(a)$ & Current tax law. \\
\hline Investment tax credit & 0.1 & Current tax law. \\
\hline Discount rate & 0.0315 & $\begin{array}{l}\text { Assumed as the real after-tax cost of } \\
\text { capital. Utility capitalization struc- } \\
\text { ture, debt, and equity costs taken from } \\
\text { Technical Assessment Guide (EPRI 1982). }\end{array}$ \\
\hline Property and other taxes & 0.01 & Annual property and other tax payment. \\
\hline $\begin{array}{l}\text { Efficiency of fossil- } \\
\text { fueled aiternative }\end{array}$ & $\begin{array}{l}9650- \\
10200 \\
\text { Btu/kWh }\end{array}$ & $\begin{array}{l}\text { This corresponds to a net heat rate for } \\
\text { a fossil-fueled power plant. This value } \\
\text { was varied in system goal calculations as } \\
\text { described in Appendix } B \text {. }\end{array}$ \\
\hline
\end{tabular}

(a) Accelerated Cost Recovery System. 
TABLE A.3. Standard Assumptions for System Goals for Industrial Process Heat (IPH)

\begin{tabular}{|c|c|c|}
\hline Variable & Value & Description \\
\hline Plant construction time & NA & $\begin{array}{l}\text { IPH system goals are based only on fuel } \\
\text { displacement, not on competing with the full } \\
\text { cost (including capital cost) of fossil } \\
\text { IPH. Construction time is irrelevant } \\
\text { because capital costs are not considered. }\end{array}$ \\
\hline Economic life & $20 \mathrm{yr}$ & $\begin{array}{l}\text { A standard assumption for an IPH plant } \\
\text { lifetime. }\end{array}$ \\
\hline Depreciation time & NA & $\begin{array}{l}\text { IPH system goals are based only on fuel } \\
\text { displacement, not on competing with the full } \\
\text { cost (including capital cost) of fossil } \\
\text { IPH. Depreciation time is irrelevant } \\
\text { because capital costs are not considered. }\end{array}$ \\
\hline Depreciation schedule & NA & $\begin{array}{l}\text { IPH system goals are based only on fuel } \\
\text { displacement, not on competing with the full } \\
\text { cost (including capital cost) of fossil } \\
\text { IPH. The depreciation schedule is irrele- } \\
\text { vant because there is no depreciation. }\end{array}$ \\
\hline Investment tax credit & NA & $\begin{array}{l}\text { IPH system goals are based only on fuel } \\
\text { displacement, not on competing with the full } \\
\text { cost (including capital cost) of fossil } \\
\text { IPH. The investment tax credit is irrele- } \\
\text { vant because capital costs are not } \\
\text { considered. }\end{array}$ \\
\hline Discount rate & 0.10 & $\begin{array}{l}\text { This value is assumed to be the real after- } \\
\text { tax cost of capital, including a risk pre- } \\
\text { mium for the variability in the price of } \\
\text { premium fossil fuels. }\end{array}$ \\
\hline Property and other taxes & NA & $\begin{array}{l}\text { Not applicahle because capital costs are not } \\
\text { included. }\end{array}$ \\
\hline $\begin{array}{l}\text { Efficiency of fossil- } \\
\text { fueled IPH system }\end{array}$ & 0.85 & $\begin{array}{l}\text { This corresponds to a net efficiency going } \\
\text { from the higher heating value of the fossil } \\
\text { fuel to the net heat absorbed into the work- } \\
\text { ing fluid. }\end{array}$ \\
\hline
\end{tabular}


TABLE A.4. Standard Assumptions for Component Goals for Electricity

\begin{tabular}{|c|c|c|}
\hline Variable & Value & Description \\
\hline Average peak insolation & 0.95 & $\begin{array}{l}\text { Representative of Southwestern United } \\
\text { States. }\end{array}$ \\
\hline Average annual insolation & $\begin{array}{l}2690 \\
\mathrm{kWh} / \mathrm{m}^{2}\end{array}$ & $\begin{array}{l}\text { Representative of insolation near } \\
\text { Barstow, California. }\end{array}$ \\
\hline Plant construction time & $3 \mathrm{yr}$ & $\begin{array}{l}\text { Representative of probable construction } \\
\text { time for large solar installation. Time } \\
\text { for small plants would be much shorter. } \\
\text { LEC is not extremely sensitive to con- } \\
\text { struction time. }\end{array}$ \\
\hline Economic life & $30 \mathrm{yr}$ & $\begin{array}{l}\text { Standard assumption for utility } \\
\text { evaluation. }\end{array}$ \\
\hline Depreciation 1 ife & $10 \mathrm{yr}$ & $\begin{array}{l}\text { Current tax law for utility investments } \\
\text { in solar generating plants. }\end{array}$ \\
\hline Depreciation schedule & $\operatorname{ACRS}^{(a)}$ & Current tax law. \\
\hline Investment tax credit & 0.10 & Current tax law. \\
\hline Discount rate & 0.0315 & $\begin{array}{l}\text { Assumed as the real after-tax cost of } \\
\text { capital. Utility capitalization struc- } \\
\text { ture and debt/equity costs taken from } \\
\text { Technical Assessment Guide (EPRI 1982). }\end{array}$ \\
\hline Property and other taxes & 0.01 & Annual property and other tax payment. \\
\hline
\end{tabular}

(a) Accelerated Cost Recovery System. 
TABLE A.5. Standard Assumptions for Component Goals for Industrial Process Heat

\begin{tabular}{|c|c|c|}
\hline Variable & Value & Description \\
\hline Average peak insolation & $\mathrm{kw} / \mathrm{m} / \mathrm{m}^{2}$ & $\begin{array}{l}\text { Representative of Southwestern United } \\
\text { States. }\end{array}$ \\
\hline Average annual insolation & $\begin{array}{l}2690 \\
k \text { Wh } / m^{2}\end{array}$ & $\begin{array}{l}\text { Representative of insolation near } \\
\text { Barstow, California. }\end{array}$ \\
\hline Plant construction time & $3 \mathrm{yr}$ & $\begin{array}{l}\text { Representative of probable construction } \\
\text { time for large solar installation. Time } \\
\text { for small plants would be much shorter. } \\
\text { LEC is not extremely sensitive to con- } \\
\text { struction time. }\end{array}$ \\
\hline Economic life $(\mathrm{a})$ & $20 \mathrm{yr}$ & $\begin{array}{l}\text { Standard assumption for industrial proj- } \\
\text { ect evaluation. }\end{array}$ \\
\hline Depreciation life $\mathrm{e}^{(\mathrm{a})}$ & $5 \mathrm{yr}$ & $\begin{array}{l}\text { Current tax law for industrial invest- } \\
\text { ments in solar energy plants. }\end{array}$ \\
\hline Depreciation schedule & $\operatorname{ACRS}^{(b)}$ & Current tax law. \\
\hline Investment tax credit & 0.10 & Current tax $1 \mathrm{aw}$. \\
\hline Discount rate ${ }^{(a)}$ & 0.10 & $\begin{array}{l}\text { Assumed as the real after-tax cost of } \\
\text { capital factoring in a risk premium for } \\
\text { the variability in the price of premium } \\
\text { fossil fuels. }\end{array}$ \\
\hline Property and other taxes & 0.01 & Annual property and other tax payments. \\
\hline
\end{tabular}

\footnotetext{
(a) Assumptions differ from electric component goals assumptions.

(b) Accelerated Cost Recovery System.
}

\section{A.2 GENERAL APPROACH TO LEC CALCULATIONS}

The first step in calculating the LEC is to calculate two economic variables required in the analysis: the capital recovery factor (CRF) and fixed charge rate (FCR). The CRF is calculated as:

$$
C F R=\frac{k}{1-(1+k)^{-N}}
$$


where

$$
\begin{aligned}
& k=\text { discount rate } \\
& N=\text { plant lifetime. }
\end{aligned}
$$

The fixed charge rate is calculated as:

$$
F C R=C R F \star[(1-t \star D P F-i t c) /(1-t)]+p
$$

where

$$
\begin{aligned}
C R F & =\text { capital recovery factor } \\
t & =\text { effective income tax rate } \\
D P F & =\text { depreciation factor (defined below) } \\
i t c & =\text { investment tax credit } \\
P & =\text { effective property and other tax rate. }
\end{aligned}
$$

The depreciation factor is calculated from the formula:

$$
\mathrm{DPF}=\frac{\sum \mathrm{dp}_{i}^{*}(1-i \mathrm{tc} / 2)}{(1+\mathrm{k})^{i}}
$$

where

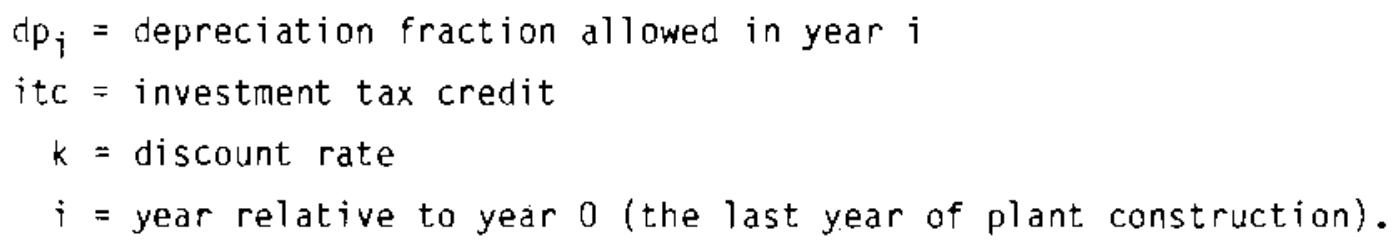
(ACRS) depreciation schedules for the appropriate tax iife of the investment. The tax 1 ife depends upon both the type of property and the ownership. ACRS depreciation schedules are summarized in Table A.6. 
TABLE A.6. ACRS Depreciation Schedules (percentage depreciation in each year)

\begin{tabular}{rrrrr}
\multicolumn{5}{c}{ Depreciation Lifetime } \\
\hline 1 & $\frac{5 \text { Year }}{15}$ & $\frac{10}{10}$ Year & $\frac{15}{\text { Year }}$ \\
2 & 22 & 14 & 5 \\
3 & 21 & 12 & 10 \\
4 & 21 & 10 & 9 \\
5 & 21 & 10 & 8 \\
6 & & 10 & 7 \\
7 & & 9 & 7 \\
8 & & 9 & 6 \\
9 & & 9 & 6 \\
10 & & 9 & 6 \\
11 & & & 6 \\
12 & & & 6 \\
13 & & & 6 \\
14 & & & 6 \\
15 & & & 6
\end{tabular}

If 1 and costs are included in the cost of the plant, a special fixed charge rate for land (FCRL) should be used because land cannot be depreciated for tax purposes. The land FCR is calculated as:

$$
F C R L=[C R F /(1-t)]+p
$$

where

$$
\begin{aligned}
C R F & =\text { capital recovery factor } \\
t & =\text { effective income tax rate } \\
p & =\text { effective property and other tax rate. }
\end{aligned}
$$

The next step in calculating the LEC is to determine the actual cash flows (nominal dollars) of all capita? costs. This can be calculated for each year of construction as: 


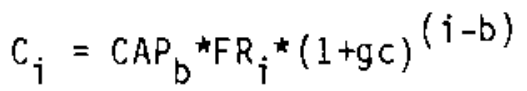

where

$$
\begin{aligned}
C_{i} & =\text { capital cost expended in year } i \\
\mathrm{CAP}_{\mathrm{b}} & =\text { total plant capital cost estimate } i \text { year } \mathrm{b} \\
\mathrm{FR}_{j} & =\text { fraction of CAPb intended to be spent in year } i \\
\mathrm{gc} & =\text { capital cost escalation rate } \\
i & =\text { year relative to year } 0 \text { (the last year of plant construction) } \\
\mathrm{b} & =\text { base year for capital cost estimate relative to year } 0 .
\end{aligned}
$$

The present value of all capital construction costs (PVC) can then be calculated as:

$$
P V C=L c_{i} /(1+k)^{i}
$$

where

$$
\begin{aligned}
C_{i} & =\text { capital cost in year } i \\
k & =\text { discount rate } \\
i & =\text { year relative to year } 0 .
\end{aligned}
$$

If land costs are included in the analysis, the present value of land (PVL) cost (assuming land is resold at the end of the plant's life) can be calculated as:

$$
P V L=\frac{L C_{b} \star(1+g l)^{(i-b)}}{(1+k)^{i}}-\frac{L C_{b} \star(1+g l)^{(N-b)}}{(1+k)^{N}}
$$

where

$$
\begin{aligned}
L C_{b} & =1 \text { and cost estimate in year } b \\
g l & =\text { land escalation rate } \\
i & =\text { year land purchased relative to year } 0 \\
b & =\text { year of land cost estimate relative to year } 0
\end{aligned}
$$




$$
\begin{aligned}
& k=\text { discount rate } \\
& N=\text { plant lifetime. }
\end{aligned}
$$

The next step is to calculate the present value of all $0 \& M$ costs, pvo. This can be calculated as:

$$
P V 0=(1-g 0)^{-b} * 0 M_{b} \star\left(\frac{1+g o}{K-g 0}\right) *\left[1-\left(\frac{1+g o}{1+K}\right)^{N}\right]
$$

where

$$
\begin{aligned}
& g o=0 \& M \text { escalation rate } \\
& b=\text { base year for 0\&M cost estimate relative to year } 0 \\
& 0 M_{b}=0 \& M \text { annual estimate in year } b \text { without allowing for escalation } \\
& k=\text { discount rate } \\
& N=\text { plant lifetime. } \\
& \text { For plants that require fuel, the present value of fuel (PVF) costs is } \\
& \qquad P V F=(1+g f)^{-b} * F_{b} *\left(\frac{1+g f}{k-g f}\right) *\left[1-\left(\frac{1+g f}{1+k}\right) N\right]
\end{aligned}
$$
calculated as:

where

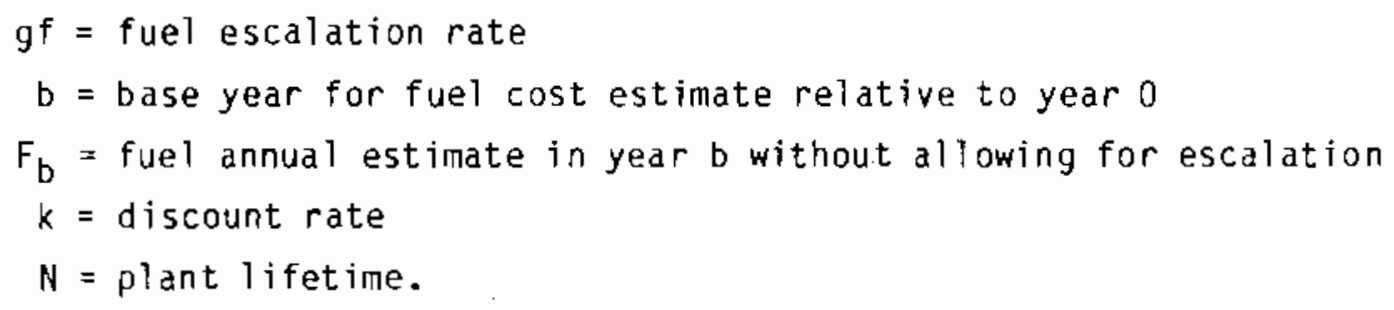

The annualized cost of the plant (expressed in year b dollars) can then be calculated as:

$$
\left.A C=(1+g i)^{b \star[F C R L \star P V L}+F R C^{\star} P V C+C R F^{\star}(P V O+P V F)\right]
$$


where

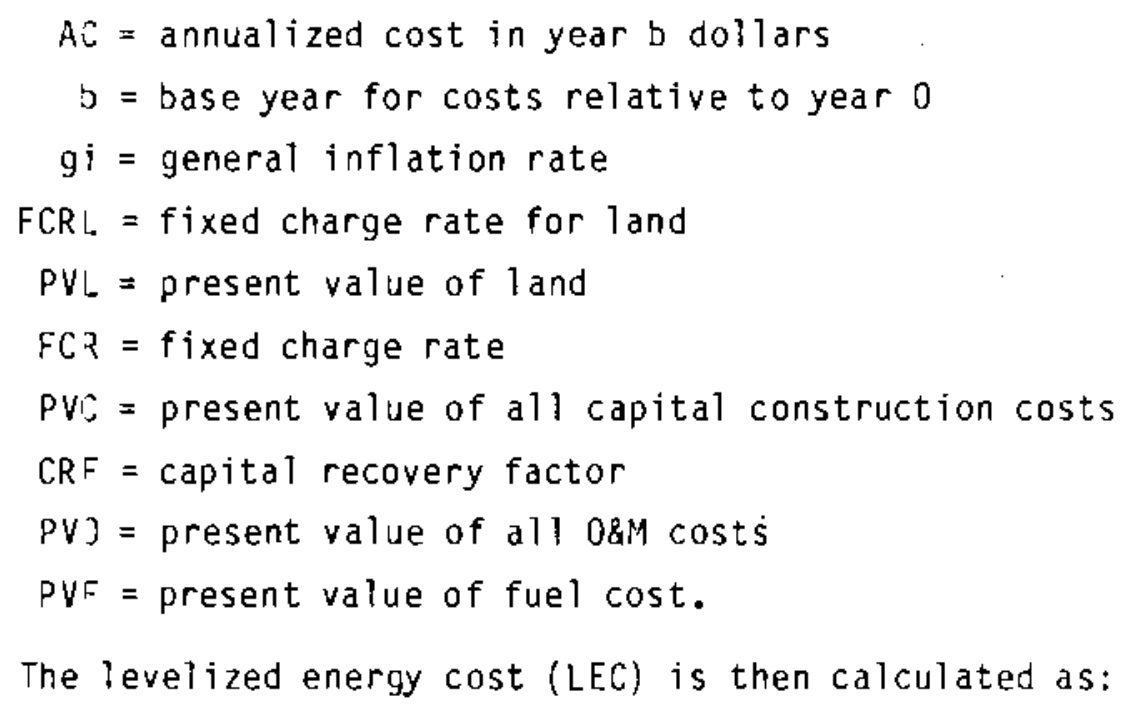

$$
L E C=A C / A O U T
$$

where

$$
\begin{aligned}
A C & =\text { annualized cost } \\
\text { AOUT } & =\text { annual energy output in appropriate units. }
\end{aligned}
$$

\section{A.3 LEC CALCULATIONS USING STANDARD ASSUMPTIONS}

This section describes a simplified approach for calculating an LEC for a solar thermal plant using the standard assumptions. If the standard assumptions are used, the LEC calculation can be reduced to only a few constants and variables. If any of the standard assumptions are not valid for the specific calculation the general LEC equations from Section A.1 must be used. Using this approach requires only the capital cost, annual 0\&M cost, and annual energy output of the solar plant as inputs. The method applies only to solar thermal plants because of differences in the depreciation basis for conventional plants.

The first step in calculating the LEC is to calculate the present value of capital investment, PVC. For the standard assumptions, this can be calculated as: 


$$
\text { PVC }=(\text { CAPITAL COSTS }) *(P V C F)
$$

where

$$
\begin{aligned}
\text { capital costs } & =\text { total capital investment cost } \\
\text { PVCF } & =\text { capital cost present value factor } .
\end{aligned}
$$

Capital cost in this calculation should not include interest during construction or escalation during construction (i.e. an "overnight" construction cost).

The second step in calculating an LEC using the standard assumptions is to determine the present value of all 0\&M costs, PVO. For the standard assumptions, this can be calculated as:

$$
\text { PVO }=\text { (ANNHAL O\&M COST)*(PVOF) }
$$

where

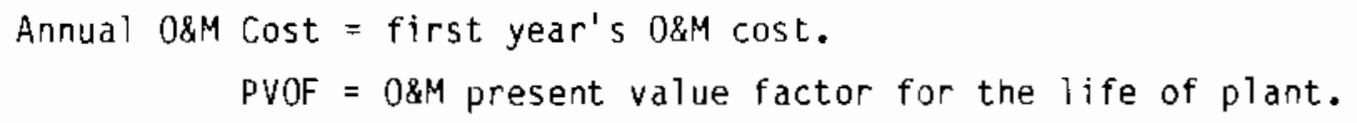

$$
L E C=\left(P V C^{\star} F C R+P V 0^{\star} C R F\right) / A O U T
$$

where

$$
\begin{aligned}
\text { FCR } & =\text { fixed charge rate } \\
\text { CRF } & =\text { capital recovery reactor } \\
\text { AOUT } & =\text { annual energy output. }
\end{aligned}
$$

Values for the economic variables in the above equations are given for both IPH and electric plants in Table A.7. 
TABLE A.7. Economic Paraneters for Solar Plant LEC Calculation Using Standard Assumptions

\begin{tabular}{lrr} 
Variable & Electric & \\
\cline { 1 - 1 } PVCF & $\frac{\text { IPH }}{1.0318}$ & 1.1033 \\
PVOF & 19.2258 & 8.5136 \\
FCR & 0.0615 & 0.1378 \\
CRF & 0.0520 & 0.1175
\end{tabular}

(a) PVCF = Capital cost present value factor.

PVOF = O\&M present value factor for the life of plant.

$F C R=$ Fixed charge rate .

$C R F=$ Capital recovery factor . 


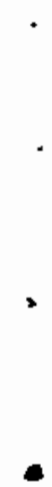

-

$$
1
$$


APPENDIX B

LEVELIZED ENERGY COST ESTIMATES FOR CDAL-FIRED POWER PLANTS 
APPENDIX B

\section{LEVELIZED ENERGY COST ESTIMATES FOR COAL-FIRED POWER PLANTS}

In ceveloping the system goals for solar thermal electricity, several scenarios were considered before the expected levelized energy cost (LEC) was estimated for coal-fired power plants during the 1995-2000 time frame. The LECs were developed to examine several alternative likely scenarios, not to develop a specific "best estimate" of the LEC for a particular plant design. These scenarios were based primarily on differences in projected coal plant capital cost and fuel costs, and were examined over a range of capacity factors for the coal plant.

The alternative scenarios examined were based on different projections of coal plant performance and costs (including capital costs, 0\&M costs, and fuel costs) from various studies. These alternative projections, when analyzed with the LEC nethodology used for the technology goals, provided a basis for establishing a competitive range of energy costs from coal-fired power plants at intermed ate capacity factors.

There are many reasons for the variations in estimated costs among the alternative coal plant cases and for the general uncertainty in projecting energy costs for coal plants. There is considerable uncertainty about the magnitude of price increases for coal, and this leads to some differences in the projected price of coal over the plants' operating lifetime. Capital costs are also an area of some disagreement among alternative studies. There is a general level of uncertainty regarding the best capital cost estimates even for current coal plants, and this uncertainty is compounded by extending the time frame that was considered to the end of the next decade. Changes in environmental regulations relating to the amount and type of environmental control technoloyy required for new coal plants could have tremendous impacts on the plant's capital cost. Finally, in actual constructicn, the impact of sitespecific factors can account for a significant difference in the plant's capital cost and in the plant's fuel cost. 
The approach used in calculating the coal plant's energy cost was to use the basic plant characteristics (such as capital cost, heat rate, fuel cost, etc.) as reported in the source reports with the levelized cost methodology and assumptions used throughout the goals development process. The use of a consistent economic methodology and consistent assumptions is essential for ensuring comparable results. Costs from the reference reports were updated to 1984 price levels to be consistent with the other calculations for the technology goals. The LEC methodology used is described in Appendix A. Basic economic assumptions used in the analysis are shown in table B.l.

TABLE B.1. Standard Economic Assumptions Used in Coal Plant Analysis

\begin{tabular}{ll}
\multicolumn{1}{c}{ Variable } & \multicolumn{1}{c}{ Value } \\
\cline { 2 - 2 } Plant construction time & 3 years \\
Economic Life & 30 years \\
Depreciation time & 15 years \\
Depreciation schedule & ACRS $(a)$ \\
Investment tax credit & 0.1 \\
Discount rate & 0.0315 \\
Property and other taxes & 0.01 \\
Construction cash flows & uniform throughout \\
Base year for prices & construction period
\end{tabular}

(a) Accelerated Cost Recovery System.

Each of the source reports used for coal plant characteristics is described in nore detail below. The report summaries are followed by the results of sensitivity analyses performed for each of the scenarios analyzed.

\section{B.1 SOURCE REPORT: REYNOLDS 1982}

This report compares the electric generation costs of nuclear and coal power plants with an initial operation date of 1995 . Projected coal plant characteristics are provided on a regional basis in the report, with information for region IX (California, Nevada and Arizona) used to establish 
LEC ranges. Summary information on the coat plant design, performance and cost (with all costs updated to 1984 dollars) are shown in Table B.2. For the baseline system described in the table, the LEC was calculated to be $\$ 0.051 / \mathrm{kWh}$ using the standard methodology.

TABLE B.2. Coal Plant Characteristics (Reynolds 1982)

$\begin{array}{ll}\text { Time Frame } & 1995 \\ \text { Plant Size } & 1200 \mathrm{MW} \\ \text { Plant Capacity Factor } & 0.65 \\ \text { Net Annual Heat Rate (Btu/kWh) } & 9652 \\ \text { Capital Cost (1984 dollars) } & \$ 1210 / \mathrm{kW} \\ 0 \& M \text { Cost (1984 dollars) } & \$ 0.0042 / \mathrm{kWh} \\ \text { Coal Cost (first year - 1984 dollars) } & \$ 2.79 / \mathrm{MBt} \\ \text { Real Price Escalation Rate for Coal } & \text { Not Available }\end{array}$

\section{B.2 SOURCE REPORT: RINGER 1984}

Projections for several different generating technologies which could begin operation in the year 1990 are summarized in this report. The plant information is site-specific to plants constructed in California. Summary information on the coal plant design, performance and cost (with all costs updated to 1984 dollars) is shown in Table B.3. For the baseline system described in the table, the LEC was calculated to be $\$ 0.061 / \mathrm{kwh}$ using the standard methodology.

IABLE B.3. Coal Plant Characteristics (Ringer 1984)

$\begin{array}{ll}\text { Time Frame } & 1990 \\ \text { Plant Size } & \text { Not Available } \\ \text { Plant Capacity Factor } & 0.65 \\ \text { Net Annual Heat Rate (Btu/KWh) } & 10,125 \\ \text { Capital Cost (1984 dollars) } & \$ 1,916 / \mathrm{KW} \\ \text { 0\&M Cost (1984 dollars) } & \$ 0.0065 / \mathrm{KWh} \\ \text { Coal Cost (first year - 1984 dollars) } & \$ 2.14 / \mathrm{MBt} u \\ \text { Real Price Escalation Rate for Coal } & 2.9 \%\end{array}$




\section{B.3 SOURCE REPORT: DELENE ET AL. 1984}

This report presents data on nuclear and fossil-fired electricity generating plants. The technology of each plant is generally characterized for current applications (as opposed to projections to a specific later date in time), although fuel price escalation rates also are presented, which allow energy cost calculations for later time periods. The report provides information on two sizes of coal plants $(550$ and $1100 \mathrm{MW})$ for several regions; the Western region data are used to establish levelized cost ranges in this analysis.

Summary information on the 550-MW and $1100-\mathrm{MW}$ coal plant design, performance and cost (with all costs updated to 1984 dollars) is shown in Tables B.4 and $B .5$, respectively. For the $550-\mathrm{MW}$ baseline system, the LEC was calculated to be $\$ 0.048 / \mathrm{kwh}$ using the standard methodology. For the $1100-\mathrm{MW}$ baseline system described in Table B.5, the LEC was calculated to be $\$ 0.045 / \mathrm{kWh}$ using the standard methodology.

TABLE B.4. Coal Plant Characteristics (Delene et al. 1984)

$\begin{array}{ll}\text { Time Frame } & 1995 \\ \text { Plant Size } & 550 \mathrm{MW} \\ \text { Plant Capacity Factor } & 0.65 \\ \text { Net Annual Heat Rate (Btu/kWh) } & 10,200 \\ \text { Capital Cost (1984 dollars) } & \$ 1,098 / \mathrm{kW} \\ \text { O\&M Cost (1984 dollars) } & \$ 0.0053 / \mathrm{kWh} \\ \text { Coal Cost (first year - 1984 dollars) } & \$ 2.16 / \mathrm{MBt} \\ \text { Real Price Escalation Rate for Coal } & 2.1 \%\end{array}$

TABLE B.5. Coal Plant Characteristics (Delene et a 1. 1984)

$\begin{array}{ll}\text { Time Frame } & 1995 \\ \text { Plant Size } & 1,100 \mathrm{MW} \\ \text { Plant Capacity Factor } & 0.65 \\ \text { Net Annual Heat Rate (Bt u/kWh) } & 10,200 \\ \text { Capital Cost (1984 dollars) } & \$ 996 / \mathrm{kW} \\ \text { 0\&M Cost (1984 dollars) } & \$ 0.0039 / \mathrm{kWh} \\ \text { Coal Cost (first year - 1984 dollars) } & \$ 2.16 / \mathrm{MBtu} \\ \text { Real Price Escalation Rate for Coal } & 2.1 \%\end{array}$




\section{B.4 SOUPCE REPORT: ELECTRIC POWER RESEARCH INSTITUTE 1982}

In this document, EPRI presents several baseline power plant design and cost estimates for comparing R\&D alternatives. Plant characteristics are provided on a regional basis in the report, with the information for the Western region used to establish LEC ranges. Summary information on the coal plant design, performance and cost (with all costs updated to 1984 dollars) is shown in Table B.6. For the baseline system described in the table, the LEC was calculated to be $\$ 0.040 / \mathrm{k}$ Wh using the standard methodology.

IABLE B.6. Coal Plant Characteristics (EPRI 1982)

$\begin{array}{ll}\text { Time Frame } & \text { Current } \\ \text { Plant Size } & 1000 \mathrm{MW} \\ \text { Plant Capacity Factor } & \text { Baseload (0.65 assumed) } \\ \text { Net Annual Heat Rate (Btu/kwh) } & 9970 \\ \text { Capital Cost (1984 dollars) } & \$ 1280 / \mathrm{kW} \\ \text { 0\&M Cost (1984 dollars) } & \$ 0.0054 / \mathrm{kWh} \\ \text { Coal Cost (first year - 1984 dollars) } & \$ 1.63 / \mathrm{MBt} u \\ \text { Real Price Escalation Rate for Coal } & 1.5 \%\end{array}$

\section{B.5 SENSITIVITY ANALYSIS}

The coal plant studies analyzed from the studies above generally considered coal power plants operating at baseload capacity factors between 0.6 and 0.7 . For each of the scenarios analyzed, a sensitivity analysis was performed to addressed the irapact of variations in the plants capacity factor on the LEC. Results of the sensitivity analyses are shown in Figure B.1. For ail of the scenarios considered, lowering the coal plant capacity factor increases the LEC jecause the capital cost contribution of the energy cost must be amortized over a lower energy output. This general sensitivity analysis did not consider the impact of the capacity factor change on the coal plants' annual heat rate or optimal design and therefore does not provide a detailed analysis of coal plant energy costs at lower capacity factors. Coal plants actually designed for intermediate loads most likely will be smaller than baseload units, which would increase the unit capital cost. Coal power plants for 


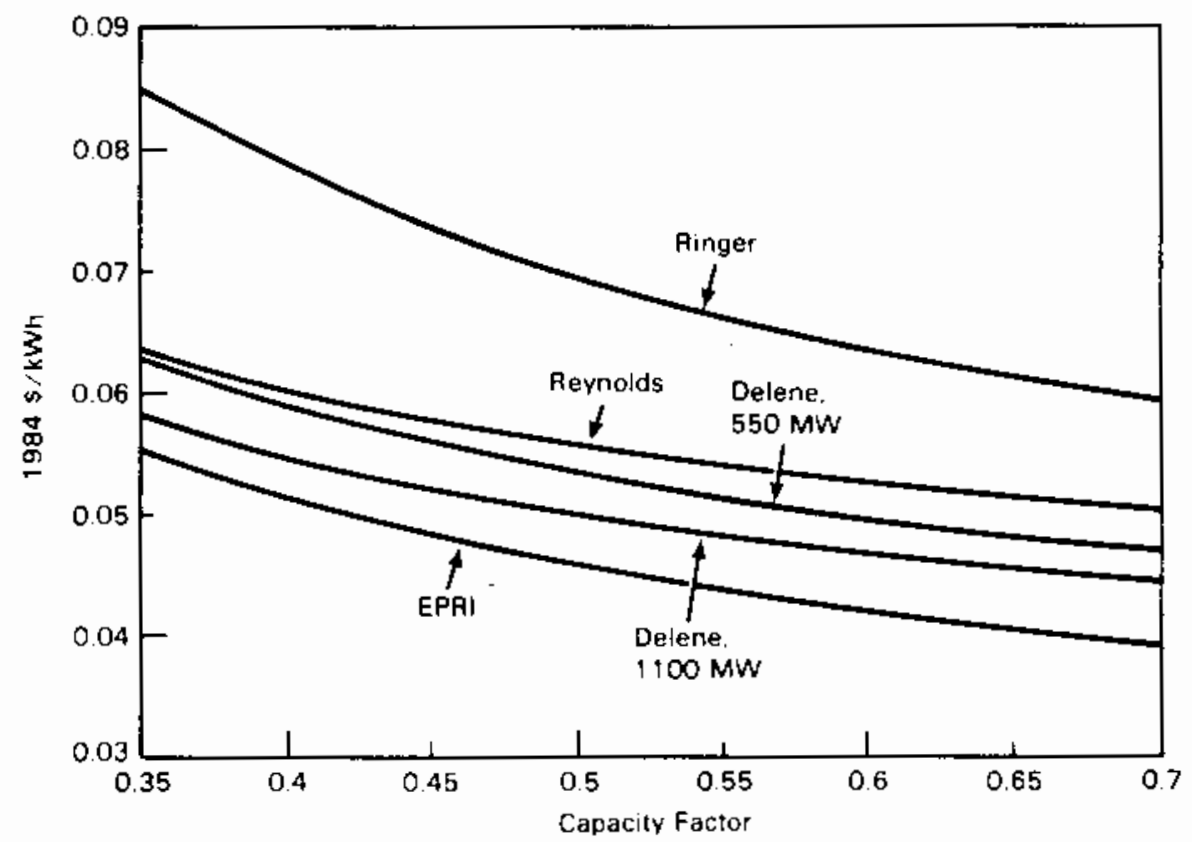

FIGURE B.l. Coal Plant Energy Costs (for varying capacity factor)

intermediate load use will also tend to have a higher heat rate than baseload plants. Both of these factors would tend to make the actual LEC for intermediate load plants higher than indicated in the sensitivity analyses. 


\section{APPENDIX C}

TECHNOLOGY DATA SHEETS 
APPENDIX C

\section{TECHNOLOGY DATA SHEETS}

This appendix contains information summarized from the Technology Data Sheets received from Sandia National Laboratories at Livermore, California, and Albuquerque, New Mexico, at the beginning of the development of solar thermal technology goals. The technology data sheets for long-term capabilities provided the starting point for developing the component goals. The first step in the process was to adjust the long-term data sheets to a consistent basis. This included breaking out efficiencies and costs where they had been 1 umped together (for instance, receivers and concentrators) or adding in costs which had not been inciuded (such as 0\&M in some cases). After the initial effort had been made to obtain self-consistent data sheets, many of the component efficiencies and costs were revised. The reasons for making these revisions included the following:

- component estimates were not consistent across technologies - for example, estimated costs for balance-of-plant (BOP) equipment.

- component goals of different technologies contained different levels of conservatism - for example, the estimated costs of concentrators, which is a critical item for goal development.

- comments from reviewers - Reviewer comments (where substantiated by either technical reports or industrial data/experience) were used to adjust some of the component goals.

- improved data - As part of the development of component goals, previous solar thermal system and component studies projecting attainable performance and cost were andyzed. In some cases this analysis developed better data sources than were used in the technology data sheets, resulting in revised estimates of achievable component performance and cost. 
- tradeoffs with system cost goals - As described in Chapter 2, in the goals development process, tradeoffs exist between goals which are attainable and goals which result in a substantial impact.

The laboratories reviewing the data sheets had the opportunity to comment on revisions to the long-term data sheets during the development of the component technology goals, during formal review cycles, and during informal discussions.

The final technology data sheets received from the laboratories are summarized in Tables C.1 to C.5.

TABLE C.1. Central Receiver Technology Data Sheet for Electricity(a)

\begin{tabular}{|c|c|c|c|}
\hline Component & $\begin{array}{c}\text { Peak } \\
\text { Efficiency }(\%)\end{array}$ & $\begin{array}{c}\text { Annual } \\
\text { Efficiency }(\%)(c)\end{array}$ & $\operatorname{cost}(\$)^{(d)}$ \\
\hline Concentrator & 0.697 & 0.599 & 60.0 \\
\hline Receiver & 0.918 & 0.884 & 9.0 \\
\hline Transport & 0.998 & 0.998 & 8.0 \\
\hline Storage & (e) & (e) & 9.0 \\
\hline Energy Conversion & 0.43 & 0.43 & 38.0 \\
\hline BOP & 0.90 & 0.91 & 16.0 \\
\hline $0 \& M$ & $N A^{(f)}$ & NA & 3.5 \\
\hline Indirects and Contingency & NA & NA & (g) \\
\hline System & 0.247 & 0.207 & 140.0 \\
\hline
\end{tabular}

(a) Plant capacity - 111 Mwe gross, 100 MWe net. Collector field size $12,500 \times 50 \mathrm{~m}^{2}=625,000 \mathrm{~m}^{2}$. Storage size - 300 MWe-hr net. Annual output - 370,000 MWe-hr net. Source: Battleson 1981.

(b) Noon, Summer Solstice.

(c) Based on available direct insolation of $17.8 \times 10^{5}$ MWt-hr (includes factors for low power cut-off but does not include forced and planned maintenance outages).

(d) Cost in July $1980 \$ M$.

(e) Not available but should be less than a $2 \% / 24-h r 10 s 5$.

(f) $N A=$ Not applicable.

(g) Included in other categories. 
IABLE C.2. Central Recejver Technology Data Sheet for Industrial
Process Heat

\begin{tabular}{|c|c|c|c|}
\hline Fomponent & $\begin{array}{c}\text { Peak } \\
\text { Efficiency }(w)(b) \\
\end{array}$ & $\begin{array}{c}\text { Annual } \\
\text { Efficiency }(\%)(c)\end{array}$ & $\cos t(\$)^{(d)}$ \\
\hline Concentrator & 0.697 & 0.599 & 60.0 \\
\hline Receiver & 0.918 & 0.884 & 9.0 \\
\hline Transport & 0.998 & 0.998 & 8.0 \\
\hline Storage & (e) & (e) & 9.0 \\
\hline Energy Conversion & (f) & (f) & $6.0^{(g)}$ \\
\hline $\mathrm{BOP}$ & (f) & (f) & 13.0 \\
\hline O\&M & $N A^{(h)}$ & NA & 3.5 \\
\hline Indirects and Contingency & NA & NA & (i) \\
\hline Systen & 0.639 & 0.528 & 105.0 \\
\hline
\end{tabular}

(a) Plant capacity - 260 Mwt. Collector field size $-12,500 \times 50 \mathrm{~m}^{2}=$ $625,000 \mathrm{~m}^{2}$. Storage size $-775 \mathrm{MWt}-\mathrm{hr}$ net. Annual output $-3.2 \times 10^{12}$ Btu or $9.4 \times 10^{5}$ Mwt-hr. Source: Battleson 1981 .

(b) Noon, Summer Solstice.

(c) Based on available direct insolation of $17.8 \times 10^{5}$ Mist-hr (includes factors for low power cut-of $f$ but does not include forced and planned maintenance outages).

(d) Cost in July $1980 \$ M$.

(e) Not available but should be less than a $2 \% / 24-h r$ loss.

(f) Not applicable.

(g) Includes only heat exchangers.

(h) NA = Not applicable.

(i) Included in other categories. 
TABLE C.3. Dish Technology Data Sheet for Electricity

\begin{tabular}{|c|c|c|c|}
\hline Component & $\begin{array}{c}\text { Peak } \\
\text { Efficiency }(z)\end{array}$ & $\begin{array}{c}\text { Annual } \\
\text { Efficiency }(z)\end{array}$ & 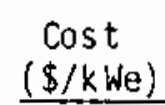 \\
\hline Concentrator & 92 & 63 & 600 \\
\hline Receiver & 93 & 93 & 300 \\
\hline Transport & $N A^{(a)}$ & NA & $N I^{(b)}$ \\
\hline Storage & NA & NA & NI \\
\hline Energy Conversion & 42 & 41 & 300 \\
\hline BOP & NI & NI & 500 \\
\hline $0 \& M$ & NI & $\mathrm{NI}$ & $\mathrm{NI}$ \\
\hline Indirects and Contingency & NI & NI & NI \\
\hline Syster & 36 & 24 & 1700 \\
\hline
\end{tabular}

(a) $N A=$ bot applicable.

(b) $\mathrm{NI}=$ No information provided.

TABLE C.4. Dish Technology Data Sheet for Industrial Process Heat

\begin{tabular}{|c|c|c|c|}
\hline Component & $\begin{array}{c}\text { Peak } \\
\text { Efficiency }(\%)\end{array}$ & $\begin{array}{c}\text { Annua } 1 \\
\text { Efficiency }(z)\end{array}$ & $\begin{array}{l}\cos t \\
(\$ k \omega t) \\
\end{array}$ \\
\hline Concentrator & 92 & 83 & 200 \\
\hline Receiver & 95 & 95 & $\begin{array}{l}\text { included } \\
\text { above }\end{array}$ \\
\hline Transport & 95 & 95 & 80 \\
\hline Storage & 96 & 96 & $N I^{(a)}$ \\
\hline Energy Conversion & $\mathrm{NA}(\mathrm{O})$ & NA & NI \\
\hline$B O P$ & NI & $\mathrm{NI}$ & 300 \\
\hline O\&M & NI & $\mathrm{NI}$ & NI \\
\hline Indirects and Contingency & NI & NI & NI \\
\hline Systern & 80 & 55 & 500 \\
\hline
\end{tabular}

(a) $\mathrm{NI}=$ No information provided.

(b) $N A=$ Not applicable. 
TABLE C.5. Trough Technology Data Sheet for Industrial Process Heat

\begin{tabular}{|c|c|c|c|}
\hline Component & $\begin{array}{c}\text { Peak } \\
\text { Efficiency }(\%)\end{array}$ & $\begin{array}{c}\text { Annual } \\
\text { Efficiency (\%) }\end{array}$ & $\operatorname{cost}(\$)$ \\
\hline Concentrator & 91 & $52^{(a)}$ & $200 / m^{2}$ \\
\hline Receiver & 76 & NI & $N I^{(b)}$ \\
\hline Transport & 98 & 94 & $90 / \pi^{2}$ \\
\hline Storage & $\mathrm{NI}$ & NI & NI \\
\hline Energy Conversion & $\mathrm{NA}(\mathrm{c})$ & NA & NI \\
\hline BOP & $\mathrm{NI}$ & NI & very low \\
\hline $0 \& M$ & NI & NI & $5 / \mathrm{ft}^{2}$ \\
\hline Indirects and Contingency & NI & NI & $5 / f t^{2}$ \\
\hline Systen & 68 & 49 & $300 / \mathrm{m}^{2}$ \\
\hline
\end{tabular}

\footnotetext{
(a) Concentrator and receivers combined into one estimate.

(b) $\quad V_{I}=$ No information provided.

(c) $\mathrm{NO}=$ Not applicable.
} 
-

$\boldsymbol{B}$

) 


\section{APPENDIX D}

PERFORMANCE ANO COST CHARACTERISTICS OF NEAR-TERM SOLAR THERMAL SYSTEMS 
APPENDIX D

\section{PERFORMANCE AND COST CHARACTERISTICS OF NEAR-TERM}

\section{SOLAR THERMAL SYSTEMS}

In the process of developing solar thermal technology goals, information was collected on the current capabilities of solar thermal systems. These estimates of near-term solar system performance and cost also appeared in DOE's Five Year plan (1984b). This appendix documents the basis for the near-term systern estimates.

A near-term system is defined as the next commercial plant which is expected to be built. Estimating the performance and cost characteristics of the next commercial solar thermal plant has significant inherent uncertainty since commercial experience to date has been limited. For central receiver electric applications, detailed designs of proposed commercial systems existed and coulc be used as the basis for the near-term systems. Similar information did not exist for dish and trough applications. Although commercial projects are also under way for these technologies, component performance and cost information was not publicly available.

Initial estimates of near-term system characteristics were obtained from Sandia National Laboratories at Livermore, California, and Albuquerque, New Mexico, ' $n$ conjunction with the technology data sheets discussed in Appendix $C$. The data sheet information received from the laboratories and used as the basis for developing near-term system estimates is summarized in Tables 0.1 through 0.4. Several of the near-term estimates were revised during discussions with the laboratories because of data inconsistencies and industry comments on the near-term system costs in drafts of the five Year Plan.

The near-term system estimates were developed to show the current perform-

ance and cost for a solar thermal system that is workable. With this approach, incompat-ble components (such as a low-temperature receiver and a hightemperature heat engine) to show the current state of the art for each component cou?d not be used. This approach was taken because it was felt that the 
TABLE D.1. Near-Term Data Sheet for Central Receiver Electricity (a)

\begin{tabular}{|c|c|c|c|}
\hline Component & $\begin{array}{c}\text { Peak } \\
\text { Efficiency }(b)^{(b)} \\
\end{array}$ & $\begin{array}{c}\text { Annual } \\
\text { Efficiency }(z)(c)\end{array}$ & $\operatorname{cost}(\$)^{(d)}$ \\
\hline Concentrator & 0.675 & 0.554 & 37.6 \\
\hline Receiver & 0.912 & 0.903 & 14.7 \\
\hline Transport & $1.011^{(e)}$ & $1.007^{(e)}$ & 13.2 \\
\hline Storage & $1.0^{(f)}$ & $1.0^{(f)}$ & 9.5 \\
\hline Energy Conversion & 0.385 & 0.385 & 30.5 \\
\hline Balance of Plant & 0.908 & 0.891 & 12.1 \\
\hline $0 \& M$ & - & - & 2.7 \\
\hline Indirects and Contingency & -- & $\ldots$ & 48.4 \\
\hline System & 0.217 & 0.173 & 166.0 \\
\hline
\end{tabular}

(a) Plant capacity - 32,7 Mwe gross, 30 Mwe net. Collector field size - 1,877 $\times 95 \mathrm{~m}^{2}=178,320 \mathrm{~m}^{2}$. Storage size -35 MHe-hr net. Annual output 75,600 MWe-hr net. Source: Rockwell 1983.

(b) Noon, spring equinox.

(c) Based on total direct insolation of about $4.8 \times 10^{5}$ Mht-hr and available direct insolation of about $4.4 \times 10^{5} \mathrm{MWt}-\mathrm{hr}$ (includes factors for $1 \mathrm{ow}$ power cut-off and plant availability). Source: Rockwell 1983.

(d) Cost in $\$ M$.

(e) Reflects energy gain from drag value operation as well as piping and storage losses.

(f) Included under transport.

most important comparison to be made in the Five Year Plan (D0E 1984b) was the energy cost of current systems to the energy cost which would be obtained by meeting the long-term technology goals. If components were selected without regard to whether they could work together as a system, it was likely that the system-level performance and LEC calculated would be completely unreasonable.

To make near-term systems comparable with the 1ong-term goals, the LEC and $\$ / \mathrm{kW}$ were calculated exactly the same for the near-term systems as was done for the goals. As much as possible, component cost breakdowns for the near-terin systems were also developed on the same basis as for the technology goals. Complete consistency in the breakdown of component costs was not always possible because of overall uncertainties in the available data for near-term systems. 
TABLE D.2. Near-Term Data Sheet for Dish Electricity

\begin{tabular}{|c|c|c|c|}
\hline Gomponent & $\begin{array}{c}\text { Peak } \\
\text { Efficiency }(\%) \\
\end{array}$ & $\begin{array}{c}\text { Arnual } \\
\text { Efficiency }(\%)\end{array}$ & $\cos t(\$ / \mathrm{kw})$ \\
\hline Concentrator & 0.90 & 0.62 & 3,200 \\
\hline Receiver & 0.91 & 0.91 & (a) \\
\hline Transport & $N A(b)$ & NA & NA \\
\hline Storage & NA & NA & NA \\
\hline Energy Cimversion & 0.41 & 0.33 & 2,900 \\
\hline Balance of Plant & NA & NA & 1,000 \\
\hline O\&M & NA & NA & $N I^{(c)}$ \\
\hline Indirects and Contingency & NA & NA & NI \\
\hline Systen & 0.34 & 0.19 & 7,100 \\
\hline
\end{tabular}

(a) Included with concentrator.

(b) $N A=$ Not applicable.

(c) NI = No information provided.

The development of the near-term system estimates for each of the solar thermal concepts is discussed below.

\section{D.1 ELEOTRIC NEAR-TERM SYSTEM FOR CENTRAL RECEIVER}

Two options were available on which to base the near-term central receiver electric system cost: the Carrisa Plains plant design and the solar 100 plant design. Carrisa piains was chosen as the basis for the near-tern systen costs. Joints in the favor of using Carrisa Plains were that the plant had received extensive DOE support; it had a preliminary design completed and an ongoing detailed design; and at the tine it appeared as if it might have a better cance for completion than Solar 100. Points against using Carrisa Plains as the basis for the near-term system were that some of the component cost estimates were higher than for the Solar 100 design, and the overall energy cost for the plant was higher than predicted for solar 100.

Allucating the cost information into the categories used for goals (concentrators, transport, etc.) for Carrisa Plains was difficult because 

TABLE D.3. Near-Term Data, Sheet for Central Receiver Industrial

\begin{tabular}{|c|c|c|c|}
\hline Component & $\begin{array}{r}\text { Peak } \\
\text { Efficiency }(\%) \\
\end{array}$ & $\begin{array}{c}\text { Annual } \\
\text { Efficiency }(\%)(c)\end{array}$ & $\cos t(\$)^{(d)}$ \\
\hline Concentrator & 0.675 & 0.554 & 37.6 \\
\hline Receiver & 0.912 & 0.903 & 14.7 \\
\hline Transport & $1.011^{(\mathrm{e})}$ & $1.007^{(\mathrm{e})}$ & 13.2 \\
\hline Storage & $1.0^{(f)}$ & $1.0(f)$ & 9.5 \\
\hline Energy Conversion & NA & NA & $\mathrm{NA}(g)$ \\
\hline Balance of Plant & NA & NA & 21.8 \\
\hline O\&M & NA & NA & 2.7 \\
\hline Indirects and Contingency & NA & NA & 39.7 \\
\hline System & 0.622 & 0.504 & 136.5 \\
\hline
\end{tabular}

(a) Plant capacity - 85 Mwt. Collector field size $-1,877 \times 95 \mathrm{~m}^{2}=$ $178,320 \mathrm{~m}^{2}$. Storage size - $100 \mathrm{MWt}-\mathrm{hr}$. Annual output $-7.5 \times 10^{11}$ Btu or $2.2 \times 10^{5}$ i wt-hr. Source: Rockwel1 1983.

(b) Noon, spring equinox.

(c) Based on total direct insolation of about $4.8 \times 10^{5}$ MWt-hr and available direct insolation of about $4.4 \times 10^{5}$ MWt-hr (includes factors for low power cut-off and plant availability).

(d) Cost in $\$$ M.

(e) Reflects energy gain from dray value operation as well as piping and storage losses.

(f) Included under transport.

(g) $N A=$ Not applicable.

detailed cost allocations were not available, and the estimated cost of Carrisa Plains changed while the near-term estimates were being developed.

The near-term system estimates for central receiver electric technology are shown in Table D.5. The basis for each of the components that are not directly taken from the data sheet estimate shown in Table D.l is described below.

Transport: The transport efficiency shown in the technology data sheet estimate was greater than 1 to account for frictional heat gains. This was reduced to an annual efficiency of 0.99 for reporting information in the Five Year Plan (DOE 1984b) because the efficiency otherwise would be greater than the 
TA3LE D.4. Trough Near-Term Data Sheet for Industrial Process Heat

\begin{tabular}{|c|c|c|c|c|}
\hline & Component & $\begin{array}{c}\text { Peak } \\
\text { Efficiency }(\%) \\
\end{array}$ & $\begin{array}{c}\text { Annual } \\
\text { Efficiency }(\%) \\
\end{array}$ & $\operatorname{cost}(\$)^{(a)}$ \\
\hline Cor & entrator (b) & 0.91 & $0.44^{(c)}$ & $235 / \mathrm{m}^{2}$ \\
\hline & iver!d) & 0.72 & (e) & (e) \\
\hline & sport & 0.98 & 0.94 & $95 / m^{2}$ \\
\hline & age & $N A^{(f)}$ & NA & NA \\
\hline & gy Conversion & NA & NA & NA \\
\hline & nce of PTant & NA & NA & $N I(g)$ \\
\hline $0 \& 1$ & & NA & NA & $20 / m^{2}$ yr \\
\hline & rects and Contingency & NA & NA & $24 / m^{2}$ \\
\hline & & 0.64 & 0.42 & $374 / m^{2}$ \\
\hline $\begin{array}{l}\text { (a) } \\
\text { (b) } \\
\text { (c) }\end{array}$ & $\begin{array}{l}\text { 198: dollars. } \\
\text { Silvered glass mirron } \\
\text { All results are from } \\
\text { Annual efficiency, al } \\
\text { glazing, would be abc } \\
\text { Receiver does not hav } \\
\text { would be } 8 \% \text { better at } \\
\text { angles. } \\
\text { Included above. } \\
\text { NA : Not applicable. } \\
\text { NI : No information }\end{array}$ & $\begin{array}{l}\text { erimental data, } \\
\text { ing for dirt and } \\
\text { the same as this } \\
\text { nti-reflective g } \\
\text { rmal incidence, } \\
\text { ided. }\end{array}$ & $\begin{array}{l}\text { h clean mirrors } \\
\text { nd, but with ant } \\
\text { r better. } \\
\text { ing. With it, } \\
\text { to } 18 \% \text { better at }\end{array}$ & $\begin{array}{l}\text { winds. } \\
\text { eflective } \\
\text { efficiency } \\
\text { gh incident }\end{array}$ \\
\hline
\end{tabular}

long-terngoal. The impact of reducing this efficiency resulted in some conservatisn in the predicted plant energy cost; if the LEC had not been calculated with the decreased transport efficiency, it would have been lower by slight ly less than a penny per kwh, a decrease of about $5 \%$.

Conversion: Energy conversion net efficiency was calculated by multiplying the energy conversion efficiency with the efficiency corrections 1 isted under BOP on the data sheet estimate shown in Table D.1.

Balance of Plant: Because no efficiencies are included for BOP in the standard reporting system used to report technology goals, the Bop efficiency (which 
IABLE D.5. Near-Term System Costs for Central Receiver Electricity

\begin{tabular}{|c|c|c|c|}
\hline Component & $\begin{array}{c}\text { Peak } \\
\text { Efficiency }(\%)\end{array}$ & $\begin{array}{c}\text { Annual } \\
\text { Efficiency }(\%) \\
\end{array}$ & Cost $(\$)$ \\
\hline Concentrator & $N A(a)$ & 0.55 & $210 / m^{2}$ \\
\hline Receiver & NA & 0.90 & $80 / m^{2}$ \\
\hline Transport & NA & 0.99 & $75 / m^{2}$ \\
\hline Storage & NA & 0.98 & $95 / k w_{t}$ \\
\hline Energy Conversion & NA & 0.34 & $1000 / \mathrm{kWe}$ \\
\hline Balance of Plant & NA & NA & $70 / m^{2}$ \\
\hline $0 \& M$ & NA & NA & $15 / m^{2}-y r$ \\
\hline System & 0.22 & 0.16 & $4600 / k$ We-peak \\
\hline Energy Cost & NA & NA & $0.16 / \mathrm{k}$ whe \\
\hline
\end{tabular}

(a) NA = Not applicable.

included plant parasitics and heat rejection) listed in the technology data sheet estimate was combined with the energy conversion efficiency as noted above.

\section{D.2 DISH ELECTRIC}

The dish electric near-term system assumed the use of a foam-glass type concentrator and a Stirling cycle energy conversion system. The fina? nearterm system estimates are shown in Table 0.6. The basis for each of the components that are not directly taken from the data sheet estimate in Table D.2 is described below.

Concentrator: Concentrator cost on the near-term data sheet was expressed in $\$ / \mathrm{kW}$ and was combined with the receiver cost. Based on information from systems analysis studies for commercial systems, a trial allocation of $\$ 650 / \mathrm{m}^{2}$ for the concentrator and $\$ 350 / \mathrm{m}^{2}$ for the receiver was developed and circulated to the laboratories and industry for review. No conments were received that lead to a revision of the allocation. 
TABLE D.6. Near-Term System Costs for Dish Electricity

\begin{tabular}{|c|c|c|c|}
\hline Component & $\begin{array}{c}\text { Peak } \\
\text { Efficiency (\%) }\end{array}$ & $\begin{array}{c}\text { Annual } \\
\text { Efficiency }(\%)\end{array}$ & $\operatorname{Cost}(\$)$ \\
\hline Concentrator & $\mathrm{NA}(\mathrm{a})$ & 0.62 & $650 / \mathrm{m}^{2}$ \\
\hline Receiver & NA & 0.90 & $350 / \mathrm{m}^{2}$ \\
\hline Transport & NA & 0.99 & $10 / m^{2}$ \\
\hline Storage & NA & NA & NA \\
\hline Ener'yy Conversion & NA & 0.33 & $2900 / \mathrm{kWe}$ \\
\hline Balance of Plant & NA & NA & $310 / \mathrm{m}^{2}$ \\
\hline $0 \& M$ & NA & NA & $15 / \pi^{2}-y r$ \\
\hline Syst emm & 0.33 & 0.18 & $8500 /$ kWe-peak \\
\hline Enerigy Cost & NA & NA & $0.38 / \mathrm{k}$ Whe \\
\hline
\end{tabular}

(a) NA = Not applicable.

Receiver: The receiver annual efficiency from the near-term data sheet was reduced :0 $90 \%$ from $91 \%$ to allow for some degradation of peak efficiency in annua? ojerations. The receiver cost of $\$ 350 / \mathrm{m}^{2}$ was developed from allocating the collector $\$ / \mathrm{kW}$ cost from the near-term data sheet discussed in the concentrator section above.

Transpor:: The transport efficiency was not given on the near-term data sheet estimate. Transport efficiency was assumed to be equal to the long-terin technology gisal. Transport costs were also not given on the near-terin data sheet estimate. Transport costs were assumed to be $\$ 10 / \mathrm{m}^{2}$, slightly higher than the long-tering goal of $\$ 7 / \mathrm{m}^{2}$.

Balance of Plant: Costs for BOP were taken from the near-term data sheet estimate, with the $\$ 10 / \mathrm{m}^{2}$ allowed for transport subtracted from the BOP costs on the nisar-term data sheet.

0\&M: No 0\&M costs were included on the near-term data sheet estimate. O\&M costs were assumed to be equal to the 084 costs for the near-term central receiver electric option. This is probably a somewhat optimistic because of the higher maintenance requirements for the Stirling engines that the dish uses than the central Rankine engine used in the central receiver electric option. 
Indirects and Contingencies: No indirect and contingency costs were included on the near-term data sheet estimate. indirect and contingency costs were estimated using the same allowance as for the long-term technology goals $20 \%$ of direct capital costs).

\section{D.3 CENTRAL RECEIVER INDUSTRIAL PROCESS HEAT}

The basis for the near-term data sheet for the central receiver near-term IPH system was the Carrisa Plains plant. The portions of the plant that related specifically to electric power generation were subtracted. Modifications to the near-term data sheet for the electric option in the cost allocation were also used for the IPH option. Final near-term system estimates are shown in Table 0.7. The basis for each of the components that are not directly taken from the data sheet estimate shown in Table 0.3 is described below.

Iransport: The transport efficiency shown in the near-term data sheet estimate was greater than $1 \%$ to account for frictional heat gains. This was reduced to an annual efficiency of 0.99 for reporting information in the five Year plan

TABLE 0.7. Near-Term System Costs for Central Receiver Industrial Process Heat

\begin{tabular}{|c|c|c|c|}
\hline Component & $\begin{array}{c}\text { Peak } \\
\text { Efficiency }(\%) \\
\end{array}$ & $\begin{array}{c}\text { Annual } \\
\text { Efficiency }(\%) \\
\end{array}$ & $\operatorname{cost}(\$)$ \\
\hline Concentrator & $N A^{(a)}$ & 0.55 & $210 / \pi^{2}$ \\
\hline Receiver & NA & 0.90 & $80 / m^{2}$ \\
\hline Transport & NA & 0.99 & $75 / m^{2}$ \\
\hline Storage & NA & 0.98 & $95 / \mathrm{kWh}_{\mathrm{t}}$ \\
\hline Energy Conversion & NA & NA & NA \\
\hline Balance of Plant & NA & NA & $120 / m^{2}$ \\
\hline $0 \& 4$ & NA & NA & $15 / m^{2}-y r$ \\
\hline System & 0.62 & 0.48 & $1300 / \mathrm{kWt}$-peak \\
\hline Energy Cost & NA & NA & $30 / \mathrm{MBtu}$ \\
\hline
\end{tabular}

(a) $N A=$ Not applicable. 
(DOE 1984b) because the efficiency otherwise would be greater than the longterm goal. The impact of reducing this efficiency resulted in some conservatism in the predicted plant energy cost; if the LEC had not been calculated with the decreased transport efficiency, it would have been lower by $\$ 1 / M B t u$, a decrease of about $3 \%$.

Storage: Storage efficiency was taken from the near-term data sheet estimate. Balance of Plant: No efficiencies are applicable to BOP. The cost for BOP includes the output heat exchangers used to transfer heat from the receiver working fluid to the process working fluid. These heat exchangers were estimated to cost $\$ 9.7$ million. This $\$ 9.7$ million was added to the BOP cost for the electric systen to estimate the total BOP cost. While it is likely that some of the BOP costs for the electric plant may not be applicable to an IPH plant in the long-term, for near-term plants it was considered a reasonable estimate to simply add the cost of output heat exchangers to the BOP for the electric plant.

\section{D.4 DISH INDUSTRIAL PROCESS HEAT}

Estimates for near-term industrial process heat applications for dish technology are shown in Table 0.8 . The costs and performance were derived from the electric estimates in Table 0.2 as described below.

Concentrator: Concentrator costs and performance were assumed to be the same as for the electricity option.

Receiver: Receiver performance was assumed to be the sane as the electricity option. This assumption is more conservative than the electric case because the receiver for IPH will be operating at lower temperatures and should have lower losses. It was not felt that the accuracy known for receiver operating efficiencies in near-term systems warranted using two different values for receiver efficiency in the Five Year Plan (DOE 1984b) for the dish electric and dish IPH near-term systems.

The receiver cost was derived from the near-term data sheet estimate of $\$ 1000 / \mathrm{kWt}$ for the concentrator and receiver combined. Subtracting the $\$ 650 / \mathrm{m}^{2}$ assumed for the concentrator left roughly $\$ 75 / \mathrm{m}^{2}$ for the receiver cost. 
TABLE D.8. Near-Term System Costs for Dish Industrial process Heat

\begin{tabular}{|c|c|c|c|}
\hline Component & $\begin{array}{c}\text { Peak } \\
\text { Efficiency }(\%) \\
\end{array}$ & $\begin{array}{c}\text { Annua } 1 \\
\text { Efficiency }(\%) \\
\end{array}$ & Cost $(\$)$ \\
\hline Concentrator & $N A(a)$ & 0.62 & $650 / \pi^{2}$ \\
\hline Receiver & NA & 0.90 & $200 / m^{2}$ \\
\hline Transport & NA & 0.93 & $110 / m^{2}$ \\
\hline Storage & NA & NA & NA \\
\hline Energy Conversion & NA & NA & NA \\
\hline Balance of Plant & NA & NA & $120 / m^{2}$ \\
\hline O\&M & NA & NA & $15 / m^{2}-y r$ \\
\hline System & 0.76 & 0.52 & $1800 / \mathrm{kwt}$-peak \\
\hline Energy Cost & NA & NA & $45 / \mathrm{MBt} \mathrm{u}$ \\
\hline
\end{tabular}

(a) NA = Not applicable.

Because the near-term data estimate was for a $200^{\circ} \mathrm{C}$ system, it was felt that this cost would be too low to be representative of receivers capable of operating in the range of $300^{\circ} \mathrm{C}$ and above. To make the receiver cost more representative of higher-temperature receivers, the cost was increased to $\$ 200 / \mathrm{m}^{2}$, roughly midway between the cost for the electric receiver and estimates of current costs for low-temperature dish receivers.

Transport: Information for transport was taken from estimates from the Shenandoah prototype plant. The transport efficiency of 0.93 represents a slight improvement over the efficiency estimates for the Shenandoah transport system, while the estimated costs are similar to the costs for Shenandoah.

Storage: Energy storage was not assumed for the near-term dish IPH systen. Conversion: Energy conversion is not required in the IPH plant.

Balance of Plant: BOP costs were assumed to be the same as for the central receiver IPH option.

Operat;ons and Maintenance: Annual 0\&M costs were assumed to be the same as for the central receiver IPH option. 
Indirect; and Contingency: Indirects and contingency costs were assumed to be equal to the same percentage as used for the long-term technology goals.

\section{D.5 TROUGH INDUSTRIAL PROCESS HEAT}

Estimated near-term system characteristics for troughs are shown in Table 0.9. Much of the cost breakdown for the near-term trough IPH system was based on input and discussions with trough manufacturers, along with information provided on the near-term data sheet in Table C.4 in Appendix $C$. Each of the component estimates is discussed below.

Concentrator: Concentrator performance of 0.44 was taken from the near-term data sheet. A value of $\$ 200 / \mathrm{m}^{2}$ was selected for the trough concentrator based on discussions with manufacturers.

Receiver: The peak receiver efficiency in the near-term data sheet was listed as 0.72 , and no annual efficiency estimate was given. Based on review of prior systems studies and discussions with industry, the peak efficiency was felt to be too low; 0.75 seemed reasonable for an annual efficiency of the receiver. The cost estimate for the receiver of $\$ 40 / \mathrm{m}^{2}$ was based discussions with manufact $\lrcorner$ rers.

TABLE D.9. Near-Term Systen Costs for Trough Industrial Process Heat

\begin{tabular}{|c|c|c|c|}
\hline Component & $\begin{array}{c}\text { Peak } \\
\text { Efficiency }(\%) \\
\end{array}$ & $\begin{array}{c}\text { Annua } 1 \\
\text { Efficiency }(\%)\end{array}$ & Cost (\$) \\
\hline Concentrator & $\mathrm{NA}^{(\mathrm{a})}$ & 0.44 & $200 / m^{2}$ \\
\hline Receiver & NA & 0.75 & $40 / m^{2}$ \\
\hline Transport & NA & 0.98 & $40 / m^{2}$ \\
\hline Storage & NA & NA & NA \\
\hline Energy Conversion & NA & NA & NA \\
\hline BOP & NA & NA & $120 / \mathrm{m}^{2}$ \\
\hline O\&M & NA & NA & $15 / m^{2}-y r$ \\
\hline Systern & 0.67 & 0.32 & $760 / \mathrm{kWt}$-peak \\
\hline Energy Cost & NA & NA & $30 / \mathrm{MBt} u$ \\
\hline
\end{tabular}

(a) NA = Not applicable. 
Transport: The transport efficiency 1 isted on the near-term technology data sheet was 0.94 annual, and 0.98 peak efficiency. The annual efficiency was felt to be low compared with estimates from previous system studies. Annual efficiencies estimated by Eicker et al. (1981) for trough transport systems generally ranged from 0.98 to 0.99 ; those estimated in Bird et al. (1981) ranged from 0.99 for low-temperature systems to 0.96 for upper temperature $\left(500^{\circ} \mathrm{F}\right)$ systems. Information in these studies lead to increasing the efficiency estimate to 0.98 for the trough transport system.

Storage: Energy storage was not assumed for the near-tern trough IPH system. Conversion: Energy conversion is not required in the IPH piant. Balance of Plant: BOP costs were assumed to be the same as for the centra? receiver IPH option.

Operations and Maintenance: Annual 0\&M costs from the near-term data sheet estimate were $\$ 20 / \mathrm{m}^{2}$ annually. Because the information available was felt not to be sufficiently detailed to discriminate between the O\&M costs for the trough IPH system relative to the dish and central receiver IPH systems, the same O\&M cost as for the other two systems $\left(\$ 15 / \mathrm{m}^{2}\right)$ was used for the trough system.

Indirects and Contingency: Indirects and contingency costs were assumed to be equal to the same percentage used for the long-term technology goals. 


\section{REFERENCES}

Apley, W. J., et al. 1980. Analysis of Electric Power Generating Costs for Systems Larger than 10 MWe. Volume I of As sessment of Generic Solar Therma? Systems for Large Power Applications. PNL-3533, Vol. I, Pacific Northwest Laboratory, Richland, Washington.

Battelson, K. W. 1981. Solar Power Tower Design Guide. SAND81-8005, Sandia National Laboratories, Albuquerque, New Mexico.

Bird, S. P., et al. 1981. Analysis of Thermal Energy Production Costs for Systems from 50 to $600 \mathrm{Mwt}$. Volume II of As sessment of Generic Solar Thermal Systems for Large Power Applications. PNL-3533, Vol. II, Pacific Northwest Laboratory, Richland, Washington.

Delene, J. G. et al. 1984. Nuclear Energy Cost Data Base. A Reference Data Base for Nuclear and Coal-Fired Power Plant Power Generation Cost AnaTysis. DOE/NE-0044/2, Oak Ridge National Laboratory, Oak Ridge, Tennessee.

Doane, J. W., et al. 1976. The Cost of Energy from Ut ility-Owned Solar Electric Systems - A Required Revenue Methodology for ERDAVEPRI Evaluations. JPL-5040-29, Jet Propulsion Laboratory, Pasadena, California.

Drumheller, K., et al. 1981. Manufacturing and Cost Evaluation of Second Generation Heliostats. In Volume 1 - Analysis and Results. PNL-3967, Pacific Northwest Laboratory, Richland, Washington.

Eicker, P. J., et al. 1981. Design, Cost and Performance Comparisons of Several Solar Thermal Systems for Process Heat. In Volume V: Systems. SAND79-8283, Sandia National Laboratories, Albuquerque, New Mexico.

Electric Power Research Institute (EPRI). 1982. Technical Assessment Guide. EPR I P-2410-SR, Electric Power Research Institute, Palo Alto, California.

Holtberg, P. D., T. J. Woods, and A. B. Ashby. 1984. 1984 GRI Baseline Projection of U.S. Energy Supply and Demand, 1983-2010. Gas Research Institute, Chicago, Illinois.

Lindberg, R. G., et al. (eds.) 1982. Environmental Effects of Solar Thermal Power Systems. UCLA 12/1372, Laboratory of BiomedicaT and Environmental Sciences, University of California, Los Angeles, California.

Radosevich, L. G. and R. S. Caputo. 1984. An Assessment of Solar Thermal Concentrator Research and Development. SAND84-8228, Sandia National Laboratories, Albuquerque, New liexico.

Reynolds, A. 1982. Projected Costs of Electricity from Nuclear and Coal-Fired Power Plants. DOE/EIA-0356/1, U.S. Department of Energy, Washington, D.C. 
Ringer, M. 1984. Relative Cost of Electricity Production. P300-84-014, California Energy Commission, Sacramento, California.

Rockwell International. 1983. "Executive Summary." Volume I of Preliminary Design of the Carrisa Plains Solar Central Receiver Power PIant. Report No. ESG-DOE-13404, Prepared by Rockwell for the U.S. Department of Energy, Washington, D.C.

Stahlkopf, K. E. 1984. A Perspective on Advanced LWRs. Electric Power Research Institute, Palo Alto, California.

U.S. Department of Energy. 1983. Energy Projections to the Year 2010. DOE/PE-0029/2, U.S. Department of Energy, Washington, D.C.

U.S. Department of Energy. 1984a. Energy Conservation Multi-Year Plan, Fiscal Year 1986-1990. U.S. Department of Energy, Washington, D.C.

U.S. Department of Energy, 1984b. Draft Five Year Research and Development Plan, 1985-1989. U.S. Department of Energy, Washington, D.C.

U.S. Department of Energy. 1984c. Staff Report, Electric Power Supply and Demand for the Contiguous United States, 1984-1993. U.S. Department of Energy, washington, D.C.

U.S. Department of Energy/Energy Information Administration. 1983. 1982 Annual Energy Outlook. DOE/PE-0029/2, U.S. Department of Energy, Washington, D.C.

Williams, T. A., et al. 1983. Solar Thermal Financing Guidebook. PNL-4745, Pacific Northwest Laboratory, Richland, Washington. 


\section{DISTRIBUTION}

No. of

Copies

\section{OFFSITE}

C. Carwile

U.S. Department of Energy

Forrestal Building

1000 Independence Ave., SW

Washington, D.C. 20585

30

H. S. Coleman

U.S. Department of Energy Forrestal Building

1000 Independence Ave., SW Washington, D.C. 20585

S. Gronich

U.S. Department of Energy

Forrestal Building

1000 Independence Ave., SW

Washington, D.C. 20585

C. Mangold

U.S. Department of Energy Forrestal Building

1000 Independence Ave., SW

Washington, D.C. 20585

F. H. Morse

U.S. Department of Energy

Forrestal Building

1000 Independence Ave., SW

Nashington, D.C. 20585

M. R. Scheve

U.S. Department of Energy Forresta 1 Building

1000 Independence Ave., SW

washington, D.C. 20585

F. Wilkins

U.S. Department of Energy

Forrestal Building

1000 Independence Ave., SW

Washington, D.C. 20585

No. of

Copies

D. Graves

U.S. Department of Energy

Albuquerque 0perations

P.0. Box 5400

Albuquerque, NM 87115

J. Weisiger

U.S. Department of Energy

Albuquerque Operations

P.0. Box 5400

Albuquerque, NM 87115

R. L. Rinne

Sandia National Laboratory

Livermore, CA 94550

A. C. Skinrood

Sandia National Laboratory

Livermore, CA 94550

L. G. Radosevich

Sandia Nationa? Laboratory

Livermore, CA 94550

H. F. Norris

Sandia National Laboratory

Livermore, CA 94550

J. C. Swearengen

Sandia National Laboratory

Livermore, CA 94550

D. B. Dawson

Sandia National Laboratory

Livermore, CA 94550

W. R. Delameter

Sandia National Laboratory

Livermore, CA 94550

3. J. Iannucci

Sandia National Laboratory

Livermore, CA 94550 
No. of

Copies

E. H. Carrell

Sandia National Laboratory

Livermore, CA 94550

P. W. Zimmerman

Sandia National Laboratory

Livermore, CA 94550

Publications Division

Sandia National Laboratory

Livermore, CA 94550

Technical Library Processes Division

Sandia National Laboratory

Livermore, CA 94550

M. A. Pound

Central Technical Files

Sandia National Laboratory

Livermore, CA 94550

D. G. Schueler

Sandia National Laboratory

P.0. Box 5800

A) buquerque, NM 87115

J. V. Otts

Sandia National Laboratory

P.0. Box 5800

Albuquerque, NM 87115

J. H. Leonard

Sandia National Laboratory

P.0. Box 5800

ATbuquerque, NM 87115

B. Gupta

Solar Energy Research Institute

1617 Cole B]yd.

Golden, CO 80401

A. A Heckes

Sandia National Laboratory

P.0. Box 5800

Albuquerque, NM 87115
No. of

Copies

L. Shannon

Solar Energy Research Institute

1617 Cole Blvd.

Golden, C0 80401

M. Carasso

Solar Energy Research Institute

1617 Cole Blvd.

Golden, C0 8040]

E. DeMeo

Electric Power Research Institute

P.0. Box 10412

Palo Alto, CA 94303

\section{OFFSITE}

DOE Richiand Operations Office

H. E. Ransom

35 Pacific Northwest Laboratory

C. H. Bloomster

D. R. Brown

G. A. Bruno

J. A. Dirks

K. Drumheller

R. G. Cavola

B. A. Garrett-Price

E. A. Griffin

R. A. Hutchinson

B. M. Johnson

B. A. Ross

R. J. Skarda

T. A. Williams (15)

R. M. Fleischman

Technical Information (MH) (5)

Publishing Coordination (2) 